$$
\text { UNIVERSIDADE DE SÃO PAULO }
$$

FACULDADE DE FILOSOFIA, LETRAS E CIÊNCIAS HUMANAS PROGRAMA DE PÓS-GRADUAÇÃO EM FILOLOGIA E LÍNGUA PORTUGUESA

\author{
ENIO SUGIYAMA JUNIOR
}

\title{
IDENTIDADES CONSTRUÍDAS E COMERCIALIZADAS: UM ESTUDO DAS DECLARAÇÕES SOBRE A IDENTIDADE DO "JAPONÊS"
}




$$
\text { UNIVERSIDADE DE SÃO PAULO }
$$

FACULDADE DE FILOSOFIA, LETRAS E CIÊNCIAS HUMANAS PROGRAMA DE PÓS-GRADUAÇÃO EM FILOLOGIA E LÍNGUA PORTUGUESA

ENIO SUGIYAMA JUNIOR

IDENTIDADES CONSTRUÍDAS E COMERCIALIZADAS: UM ESTUDO DAS DECLARAÇÕES SOBRE A IDENTIDADE DO "JAPONÊ'"

Dissertação apresentada ao Programa de Pós-Graduação em Filologia e Língua Portuguesa do Departamento de Letras Clássicas e Vernáculas para a obtenção do título de Mestre em Filologia e Língua Portuguesa.

Orientador: Prof. Dr. Valdir Heitor Barzotto. 


\section{Resumo:}

Nesta pesquisa, busquei responder duas perguntas: a) Quais operações discursivas são utilizadas pelos sujeitos ao realizarem afirmações sobre a identidade étnica e lingüística de um grupo específico? b) Quais são as implicações dessas operações discursivas sobre a produção dos enunciados? Escolhi como objeto de estudo enunciados que foram produzidos em diferentes condições de produção, mas que buscam delinear a identidade étnica e lingüística associadas aos imigrantes japoneses e seus descendentes. A partir das análises realizadas, podem-se depreender algumas implicações entre as representações associadas às identidades e a produção dos próprios enunciados na tentativa de neutralizar as representações consideradas disfóricas em relação à identidade étnica japonesa. Ao se adotar essa postura, os enunciadores apropriam-se de recursos lingüísticos que possam funcionar como marcadores de suas próprias identidades. É esse processo que dá origem às condicionantes discursivas. O funcionamento dessas condicionantes discursivas atua tanto na produção lingüística quanto no processo de uniformização da língua, pois cria identidades consideradas ideais, as quais podem ser assumidas pela adesão às representações e à (re)produção dos recursos lingüísticos que supostamente estariam associados a essa identidade.

Palavras-chave: Declarações de Identidades, Identidade étnica, Identidade Lingüística, Nipo-Brasileiros, Análise do Discurso 


\section{Abstract:}

In this research, I've tried to answer two questions: a) Which discursive operations were used by subjects when they declare their ethnic and linguistic identity? B) Which were the implications of theses discursive operations in the production of the declaration? I've chosen as a study object declarations which were produced in different production conditions but they have a similar trace: try to define the identity of Japanese people and their descendent. Considering the analyses, it's possible to infer some implications between the representations associated to the Japanese identity and the declarations product in order to neutralize dysphoric representations. When they adopt this attitude, the enunciators appropriate linguistics features that work as their own identity mark. These discursive conditions operate on either the linguistic production and the language uniformity process, because it creates ideal identities that can be adopted by the acceptance of the representations and the reproduction of linguistic features associated to this identity.

Keywords: Identity Declaration, Ethnic Identity, Linguistic Identity, JapaneseBrazilian, Discourse Analysis 


\begin{abstract}
À Maria de Fátima Ferreira de Souza Sugiyama, Enio Sugiyama e Diego Sugiyama que mesmo sem compreender os porquês, estiveram do seu lado sempre
\end{abstract}




\section{AGRADECIMENTOS:}

Ao Prof. Dr. Valdir Heitor Barzotto

por me fazer caminhar!

À Profa. Dra. Claudia Rosa Riolfi

por ensinar que rigor e risada não estão em lados opostos na vida acadêmica.

À Profa. Dra. Marli Quadros Leite e Prof. Dr. Mário Eduardo Viaro

pela leitura atenciosa e pelas ricas contribuições feitas na ocasião do exame de qualificação.

À Emari Andrade, Rafael Barreto do Prado e Suelen Gregatti da Igreja

pelas inúmeras leituras e contribuições realizadas ao longo da escrita desta dissertação

À Mariana Aparecida de Oliveiro Ribeiro

sempre pronta a discutir aquele conceito obscuro durante o lanche da tarde

À Larissa, Jordana, Elaine, Carol, Betto, Juliana, Mauricio, Brunos, Jeffy, Aline, Sulemi, Cibele, Razi, Thigos, Hamed e tantos outros que utilizaram a proposição “amanhã não posso, tenho reunião com o prof. Valdir" como motivo para piada, ao invés da expulsão do circulo de amizades

A todos os amigos do Grupo de Estudos e Pesquisa Produção Escrita e Psicanálise 


\section{SUMÁRIO}

INTRODUÇÃO

MEUS PRECEDENTES

OPÇÕES TEÓRICAS

MODELOS SOCIOLINGÜÍSTICOS

O MODELO DA ANÁLISE DO DISCURSO 19

PROCEDIMENTOS DE ANÁLISE E CONSTITUIÇÃO

DO CORPUS 24

APRESENTAÇÃO E ANÁLISE DE DADOS

CAPÍTULO 1 TRAÇOS DAS REPRESENTAÇÕES DO "JAPONÊS": UM ESTUDO DAS DECLARAÇÕES SOBRE A IDENTIDADE ÉTNICA 31

$\begin{array}{llllll}1.1 & A & \text { IDENTIDADE } & \mathrm{E} & \text { OS } & \text { TRABALHOS }\end{array}$ SOCIOLINGÜÍSTICA LABOVIANA 32

$1.2 \quad$ A IDENTIFICAÇÃO NA PSICANÁLISE 35

1.3 DO CORPO DESPEDAÇADO À UNIDADE DO SIGNFICANTE $\quad 36$

1.4 O PANORAMA HISTÓRICO 40

1.5 FIGURAS DO JAPONÊS POR MEIO DA MÍDIA 42

$\begin{array}{lll}\text { 1.5.1 PRIMEIRAS IMAGENS } & 42\end{array}$

1.5.2 DA CONTINUIDADE DO IMAGINÁRIO 48

1.6 FIGURAS DA PRÓPRIA COMUNIDADE NIKKEI: OS REPRESENTANTES DAS ENTIDADES NIPOBRASILEIRAS $\quad 55$

REPRESENTAÇÕES DA IDENTIDADE NAS
DECLARAÇÕES DE NIPO-BRASILEIROS

1.8 DA CIRCULAÇÃO DE REPRESENTAÇÕES ÀS

CAPÍTULO 2 AS REPRESENTAÇÕES DA LINGUAGEM: ESTUDO DAS DECLARAÇÕES SOBRE A LÍNGUA

$\begin{array}{lllll}2.1 & A & \text { IDENTIDADE } & \text { LINGÜISTICA } & \text { FRENTE À }\end{array}$ REALIDADE PLURILINGÜÍSTICA

2.2 IDENTIDADE LINGÜÍSTICA COMO MANIFESTAÇÃO FRENTE ÀS NÃO-COINCIDÊNCIAS DO DIZER

2.3 IDENTIDADE LINGÜÍSTICA VERSUS LÍNGUA MATERNA 74

2.4 A REPRESENTAÇÃO DA LÍNGUA FALAdA PELO IMIGRANTE JAPONÊS: $O$ BATYANÊS 
A REPRESENTAÇÃO DO NÃO-UM DA IDENTIDADE LINGÜÍSTICA DO BATYANÊS REPRESENTAÇÕES DOS VALORES ATRIBUÍDOS À IDENTIDADE LINGÜÍSTICA DOS IMIGRANTES JAPONESES

CAPÍTULO 3 REPRESENTAÇÕES E PRODUÇ̃̃O LINGÜÍSTICA: UM ESTUDO DAS CONDICIONANTES DISCURSIVAS NO PROCESSO DE UNIFORMIZAÇÃO DA LINGUAGEM A COMPOSIÇÃO DOS ENUNCIADOS E A DIREÇÃO DA SIGNIFICAÇÃO ENTRE A DECLARAÇÃO DE ACOLHIMENTO E A ATITUDE DE REJEIÇÃ O 
LISTA DE TABELAS

TABELA 1

TABELA 2

81

TABELA 3

83

TABELA 4

\section{LISTA DE FIGURAS}

FIGURA 1

FIGURA 2

43

FIGURA 3

44

FIGURA 4

49

FIGURA 5

50

FIGURA 6

51

FIGURA 7 


\section{Introdução}

Afinal, o que fazemos quando falamos?

Schlieben-lange (1993:18)

Formulações parecidas como a pergunta de Schlieben-Lange, que abre esta dissertação, podem ser encontradas nos títulos de trabalho como o de Bourdieu (1982) Economia das trocas lingüísticas - o que falar quer dizer? - e de Austin (1962) How to do things with words. Trata-se de uma questão que é objeto de discussão em diversos estudos que tomam a linguagem como objeto de investigação.

É por meio da linguagem que se abre a possibilidade para que os sujeitos possam realizar afirmações acerca do mundo, de si mesmo, do outro e também a respeito da própria linguagem. Para Benveniste (1958), é a linguagem que permite um locutor se afirmar em uma instância de "eu”, em suas palavras, "porque só a linguagem fundamenta na realidade, na sua realidade que é a do ser, o conceito de 'ego' (op.cit: 289).

O autor se dedica ao estudo das formas lingüísticas que expressariam a subjetividade na linguagem como as conjugações verbais, os dêiticos e, em especial, os pronomes pessoais. É por meio da análise dos pronomes pessoais (eu/ tu) que Benveniste considera a instância de eu no nível discursivo, uma vez que tais pronomes não possuem conceito nem referência fora do processo de enunciação. Assim, a posição "eu" - "tu" alterna-se de acordo com o locutor que assume o turno.

\footnotetext{
Não há conceito "eu" englobando todos os eu que se enunciam a todo instante na boca de todos os locutores, no sentido em que há um conceito "árvore" ao qual se reduzem todos os empregos individuais de árvore. O "eu" não denomina pois nenhuma entidade lexical. Poder-se-á dizer, então, que "eu" se refere a um indivíduo particular? Se assim fosse haveria uma contradição permanente admitida na linguagem, e anarquia na prática: como é que o mesmo termo poderia referir-se indiferentemente a qualquer indivíduo e ao mesmo tempo identificá-lo na particularidade? (op. cit.: 288)
}

A partir dos trabalhos de Benveniste, uma das respostas que poderia ser dada à questão que abre a introdução deste trabalho é que quando falamos podemos nos 
apropriar de formas lingüísticas pelas quais expressamos a subjetividade na linguagem, ou seja, assumimos a posição de sujeito.

Se por um lado os estudos de Benveniste permitiram um avanço na consideração da subjetividade na linguagem, por outro, os trabalhos desenvolvidos no Grupo de Estudos e Pesquisa Produção Escrita e Psicanálise - GEPPEP têm salientado que a subjetividade de que se trata não é condição suficiente para a expressão de uma identidade $^{1}$ (MAGALHÃES (2007); OLIVEIRA (2008) e BARZOTTO \& RIOLFI (2008)). De modo geral, esses trabalhos se dedicam aos processos por meio dos quais uma pessoa pode vir a ocupar uma posição enunciativa a partir da qual seja possível reconhecer a construção de uma identidade que a diferencie do discursivo corrente.

Nessa perspectiva, o fato de haver uma apropriação do aparelho formal da enunciação (BENVENISTE, 1970) não é condição suficiente para que a produção possa exibir traços de subjetividade, uma vez que esses enunciados podem estar submetidos a condicionantes que buscam apagar a subjetividade para assumir uma posição considerada como ideal.

O fato dos enunciados estarem submetidos a condicionantes discursivos constitui uma das perspectivas de trabalho adotada no GEPPEP. Inspirados nos trabalhos de Foucault (1970), os trabalhos de Rocha (2007), Anjos (2008) e Igreja (2008) voltam-se aos procedimentos de controle que organizam e selecionam a produção do discurso. Esses trabalhos versam a respeito de procedimentos lingüísticos e discursivos utilizados pela mídia impressa, em veículos de grande circulação no Brasil (a revista Nova escola e os jornais Folha de São Paulo e Estado de São Paulo) para tornar o dizer hegemônico.

Levar em conta a produção dos trabalhos acima implica investigar a submissão dos enunciados, inclusive aqueles produzidos em primeira pessoa do singular, a esses procedimentos de controle, uma vez que uma identidade pode ser apagada por tais procedimentos para a instauração de um dizer representante da posição ideal a ser assumida. Dessa forma, para respondermos à questão Afinal, o que fazemos quando falamos? é preciso considerar em que medida não reproduzimos os procedimentos de controle do dizer contribuindo, assim, para a instauração de um dizer hegemônico.

\footnotetext{
${ }^{1} \mathrm{O}$ termo identidade possui diversas acepções de acordo com o quadro teórico em que é empregado. Neste trabalho, será utilizado para se referir às declarações nas quais os sujeitos busquem definir a si próprios, o outro ou a linguagem. A discussão será retomada em dois momentos desta dissertação: no capítulo um, que tem como foco a identidade étnica, e no capítulo dois dedicado à identidade lingüística.
} 
Essas reflexões se tornam relevantes para esta dissertação que toma como objeto enunciados que buscam delinear a identidade associada aos imigrantes japoneses e seus descendentes. As análises visam a descrever os procedimentos utilizados para construção desses enunciados e a implicação de tais procedimentos para a produção lingüística.

Trata-se de um trabalho inserido no projeto Imagens da língua: sujeito, conhecimento e tempo coordenado pelo Prof. Dr. Valdir Heitor Barzotto, no programa de pós-graduação em Filologia e Língua Portuguesa. De modo geral, o projeto trabalha com textos da mídia, textos acadêmicos e de normatização como meio de depreender a existência de condicionantes que resultem de operações discursivas realizadas sobre recursos lingüísticos que contribuam para a efetivação de mudanças lingüísticas e incorporação de itens lexicais de grupos específicos por um número maior de falantes.

Minha contribuição ao projeto está relacionada com o estudo das operações discursivas realizadas por diferentes sujeitos nas declarações a respeito da identidade étnica/lingüística de um grupo específico. São duas as questões que norteiam esta dissertação:

a- Quais operações discursivas são utilizadas pelos sujeitos ao realizarem declarações sobre a identidade étnica e lingüística de um grupo específico?

b- Quais são as implicações dessas operações discursivas sobre a produção dos enunciados?

Além da contribuição ao projeto de pesquisa Imagens da língua, este trabalho se insere nos estudos que têm tomado a comunidade nipo-brasileira como objeto para pesquisas lingüísticas. Esses estudos, filiados à sociolingüística, realizam recortes a partir do qual analisam a língua japonesa falada por imigrantes e seus descendentes (KUYAMA, 1999 e MATSUZAKI, 2005), a língua portuguesa (KANASHIRO, 2000) e a interação entre as duas línguas (NAWA, 1989 e GARDENAL, 2008).

Apesar de todos os trabalhos apresentarem a caracterização da comunidade escolhida para análise com informações históricas a respeito da identidade nipobrasileira, de modo geral os trabalhos citados acima se dedicam à caracterização de um 
fenômeno lingüístico apresentado na fala dos informantes selecionados para compor o corpus de seus trabalhos.

Nesse panorama, meu trabalho pode contribuir para as discussões acerca da comunidade nipo-brasileira a partir de um outro ponto de vista, uma vez que aborda as produções lingüísticas relacionadas a essa comunidade por meio das declarações da identidade do grupo.

\section{MEUS PRECEDENTES}

As análises desta dissertação se colocam como prosseguimento à minha pesquisa de Iniciação Científica ${ }^{2}$. Naquela pesquisa, buscava compreender os procedimentos que permitiam a reprodução por mais de três décadas de um discurso que relaciona Linguíística ao ensino de Língua Portuguesa, produzindo o que foi nomeado de discurso-eixo. O fenômeno a que me refiro está ligado à articulação de dois pólos argumentativos ${ }^{3}$ simétricos em um mesmo discurso, a saber:

a) a existência de problemas relacionados com os processos de ensinoaprendizagem do ensino da Leitura e da Escrita na escola; e

b) possíveis soluções produzidas no interior de uma disciplina científica, a Lingüística.

A reprodução desses dois pólos durante mais de trinta anos em um discurso-eixo que os articulava, torna-os aparentemente antagônicos, visto que caso o pólo argumentativo "b" (soluções) houvesse causado efeito, o pólo "a" (problemas) deixaria de ser propagado e, circularmente, "b" se diluiria em novos dizeres, deixando de ser reproduzido.

Para investigar os procedimentos utilizados para a reprodução do discurso-eixo, tomei como corpus seis dissertações de mestrado que tinham como traço comum o fato das autoras terem exercido a função de professoras do Ensino Fundamental e Médio e

\footnotetext{
2 Trata-se da pesquisa Lingüística e Metodologias do Ensino de Língua Portuguesa: limites e possibilidades da circulação do conhecimento realizada na Faculdade de Educação da Universidade de São Paulo, na modalidade com bolsa PIBIC- CNPq, de 2004 a 2006.

${ }^{3}$ Os eixos-argumentativos estão expostos da maneira como foram depreendidos do discurso-eixo, não sendo fruto de nenhuma investigação sobre os problemas ou soluções efetivamente.
} 
realizarem uma espécie de testemunho escrito que narrava a motivação para pesquisa sempre relacionada ao contato com o discurso-eixo.

Essas dissertações foram submetidas a uma leitura que visava a depreender a relação estabelecida entre a autora e o discurso-eixo por meio da análise dos modos de apropriação (CHARTIER, 1990) ${ }^{4}$ dos textos representantes desse discurso. Para realizar essa leitura, contrastei as representações associadas à Lingüística contidas no testemunho das dissertações com as análises efetuadas pelas autoras, levando em consideração a seguinte questão: Qual é a relação estabelecida pela autora do trabalho entre os efeitos que narra e a sua prática de análise?

O exercício de leitura acima permitiu dividir os trabalhos em dois grandes grupos, de acordo com a relação que as autoras mantiveram com o discurso-eixo. No primeiro grupo, encontram-se os trabalhos que permanecem fixados dentro da verdade transmitida pelo discurso-eixo, tomando tal discurso como solução para os problemas levantados pela pesquisa. No segundo grupo estão os trabalhos nos quais foi possível observar um deslocamento com relação a este discurso.

Nos trabalhos do primeiro grupo, os textos representantes do discurso-eixo foram utilizados para compor a fundamentação teórica, servindo como fonte para a apropriação de termos produzidos nas diversas áreas de Lingüística. No entanto, a utilização desses termos não implicava o funcionamento dos princípios da área na análise de dados. Dessa forma, o próprio emprego dos termos era considerado como forma de realizar a análise de dados, funcionando como marcador de identificação à verdade do discurso-eixo e uma pretensa inclusão no grupo de lingüistas.

As autoras do primeiro grupo, uma vez identificadas com a verdade do discurso da Lingüística, apropriam-se de expressões desse discurso produzindo enunciados que têm como principal função reafirmar o que é tomado como verdade, não abrindo espaço para novos dizeres. Observa-se um corte com o dizer anterior no qual se declaravam professoras "tradicionais" para um novo dizer em que buscam se declarar "lingüistas". No entanto, nas duas declarações observa-se a adesão a uma verdade pré-estabelecida em detrimento das experiências da autora, sem causar nenhum deslocamento subjetivo necessário para a construção de um novo discurso.

No segundo grupo, selecionei os trabalhos em que foi possível perceber que a relação que as autoras estabelecem com o discurso-eixo era diferente: mesmo

\footnotetext{
${ }^{4}$ A noção de apropriação elaborada por Chartier (1990), dentro da História Cultural, será apresentada e aprofundada no quadro teórico desta dissertação.
} 
relacionando a motivação do trabalho com o contato com esse discurso, as autoras não atribuíram a ele valor de verdade e puderam deslocar de posição ao tomarem o próprio discurso-eixo como corpus para a escrita de suas dissertações.

Esse deslocamento pode ser pontuado com a busca de apoio em uma teoria, a Análise do Discurso de linha francesa, fato que faz com que as autoras se sintam autorizadas a realizar a atribuição de um sentido a esse discurso, uma vez que se encontraram em uma outra posição, que é a do paradigma científico. Se com relação ao discurso-eixo existe um deslocamento de posição, este deslocamento não é suficiente para barrar a (re)produção do mesmo. Trata-se de uma resposta que atribui a este discurso um sentido, mas que não consegue deslocá-lo.

Observam-se dois movimentos diferenciados no segundo grupo, o primeiro em relação ao sentido do discurso-eixo, que passa de lugar de verdade para o de lugar de causador do "não-saber" (a-científico), e, segundo, em relação ao discurso da ciência, que é o instrumento necessário para o distanciamento e que se torna o lugar do qual a verdade sobre o discurso-eixo pode ser enunciada.

Os procedimentos identificados nos dois grupos, em meu trabalho de Iniciação Científica, permitiram compreender a reprodução dos pólos argumentativos aparentemente antagônicos que se articulavam no discurso-eixo. Esta compreensão foi elaborada a partir da investigação da relação estabelecida pelas autoras em seus trabalhos com o discurso-eixo. Meu trabalho buscou ir além de uma descrição dos argumentos utilizados pelas autoras dos trabalhos, focando-se sobre os mecanismos que sustentam o discurso-eixo sem que haja uma responsabilização por parte de quem escreve.

Ao fim deste primeiro percurso de pesquisa na universidade, duas questões se colocaram para mim, a saber:

1) Uma vez que a relação das autoras com o discurso-eixo estava condicionada aos processos de reprodução do mesmo e, por isso, não foi possível realizar afirmações acerca das contribuições (ou não) da Lingüística ao ensino de Língua Portuguesa, qual seria o efeito da Lingüística no ensino de Língua Portuguesa? e

2) Uma vez que a compreensão dos procedimentos de reprodução do discurso-eixo só pode ser desvelada ao abandonar uma tentativa reguladora do dizer e ao investir na descrição da relação estabelecida entre a autora do trabalho e o discurso-eixo, qual é a 
viabilidade de se pensar em uma linha de investigação lingüística que busque a descrição dos efeitos da oferta de recursos lingüísticos nas relações estabelecidas?

Os resultados de minha pesquisa de Iniciação Científica, que permitiram chegar à segunda questão acima apresentada, a qual serviu de base para o desenvolvimento do estudo que ora apresento, estão relacionados à necessidade de uma investigação do oferecimento de recursos lingüísticos como uma forma de exercer uma ação uniformizadora da linguagem (BARZOTTO, 1998).

Em seu trabalho, Barzotto dedica-se à análise de um periódico e realiza uma leitura que considera elementos que ultrapassam o texto, delineando movimentos em que os discursos e, inclusive, a materialidade do suporte de textos, atuam para a constituição dos efeitos de sentido.

Mesmo considerando que não há possibilidade de se prever a leitura que será efetivada pelo leitor, Barzotto aponta para os elementos presentes na revista periódica por ele analisada (o texto, o suporte e o discurso), que buscam delinear ações que incidem na constituição não somente de sentidos, mas, também, de um modo de vida e de relação com o mundo.

Um modo de vida em que recursos lingüísticos entram como marcadores de identidade, quase da mesma natureza de outros acessórios, de um grupo que busca integrar-se a esse tempo, fugindo da parcela social sobre a qual recai o maior peso da exclusão. (op.cit.: 125).

É dentro deste modo de funcionamento que pude inscrever as dissertações analisadas em minha Iniciação Científica. Seja porque a partir do discurso-eixo as autoras recolheram recursos lingüísticos contidos nos textos que ofertavam a possibilidade de inscreverem-se em uma comunidade e em um tempo tido como adequados (primeiro grupo), seja porque atribuíram um valor negativo a esse discurso, tornando-o descartável, por terem adentrado em outro grupo (segundo grupo).

Nesta pesquisa, tomo como objeto enunciados que buscam delimitar a identidade étnica e lingüística associada ao imigrante japonês e seus descendentes para depreender a relação estabelecida entre as representações dessas identidades e a produção dos enunciados. O trabalho que apresento se coloca como continuidade da investigação dos efeitos produzidos pelas representações da identidade de um grupo específico na produção de enunciados. 
Além dos processos de constituição dos enunciados, no presente trabalho, interessa-me acentuar os efeitos que tais processos exercem na produção lingüística, uma vez que esses processos podem sustentar um projeto de uniformização da linguagem, servindo como forma de sustentação e disseminação de recursos lingüísticos.

\section{OPÇÕES TEÓRICAS}

Neste momento, cumpre traçar as opções teóricas feitas para responder as questões que norteiam este trabalho. Para cumprir esta tarefa, iniciarei por uma apresentação dos procedimentos utilizados pela sociolingüística, tendo em vista que os problemas discutidos nesta dissertação também são objetos de investigação dessa área dos estudos da linguagem.

$\mathrm{Na}$ apresentação dos trabalhos da sociolingüística, o trabalho de SchliebenLange (1993) ganha importância por permitir uma aproximação das ações envolvidas na atividade do falar que não é possível de ser apreendida pelo método de análise quantitativo. A construção do quadro teórico para análise seguirá, portanto, um outro modelo, elaborado a partir da Análise do Discurso (AD), representada especialmente pelos trabalhos de Pêcheux.

Apesar das diferenças metodológicas de análise da sociolingüística, em especial na sua vertente laboviana, com a AD é possível estabelecer pontos de contato entre as duas áreas. É o que expõe Orlandi ao abordar a questão: (1981:111-112):

(...) algo que até o momento foi pouco explorado e merece uma maior atenção é a relação da análise do discurso com a sociolingüística, uma vez que os pontos comuns na consideração do objeto de que tratam são evidentes, (...) mais do que isso, sabemos que o termo sociolingüística recobre trabalhos extremamente diversos - etnografia da comunicação, variação lingüística e até mesmo análise de discurso - ou seja, trabalhos que tratam da análise da linguagem no contexto.

As elaborações produzidas pela $\mathrm{AD}$ permitem uma abordagem dos enunciados que busca extrapolar as relações textuais na medida em que considera as condições de produção (PÊCHEUX, 1969) como parte necessária da análise tomando a enunciação como processo constitutivo da produção lingüística. 


\section{MODELOS SOCIOLINGÜÍSTICOS}

A tentativa de estabelecer os fatores que atuam na produção lingüística dos falantes constitui o objetivo de diversas áreas dos estudos da linguagem, em especial, da sociolinguiística. Dentro desta grande área, lingüistas com diferentes referenciais teóricos e abordagens metodológicas têm se dedicado a uma descrição da língua levando em consideração as relações existentes entre sociedade e linguagem.

Estes estudos, de maneira geral, buscam compreender quais os fatores sociais e lingüísticos estão envolvidos no (des) favorecimento do uso de uma determinada variante. Também é tema dos estudos sociolingüísticos a construção de julgamentos que os falantes realizam sobre seu próprio falar ou do falar de uma outra comunidade. Em ambos os casos, busca-se a descrição dos fatores sociolingüísticos envolvidos nos problemas de pesquisa.

Dentro da grande variedade de pesquisas realizadas sob o domínio da sociolingüística, uma corrente que já alcançou um grande espaço foi a chamada Sociolingüística Variacionista quantitativa. Como argumento em favor desta afirmação, nota-se a produção do livro Introdução à Sociolingüística - o tratamento da variação, organizado por Maria Cecília Mollica e Maria Luiza Braga (2003), ambas professoras da Universidade Federal do Rio de Janeiro.

Este livro, que se propõe a oferecer uma visão panorâmica dos estudos ligados a esta vertente, torna-se ilustrativo por trazer diferentes aspectos abordados e um grande número de estudos desenvolvidos na área. Observa-se que a grande preocupação das autoras é demonstrar como elementos intra e extralingüísticos são importantes no (des) favorecimento do uso de uma determinada variante.

Os estudos realizados dentro desta abordagem trabalham com um fenômeno de variação localizado, ou seja, estará em jogo um único fenômeno que poderá se manifestar de modos diferentes, as chamadas variantes. Por exemplo, o fenômeno de variação pode ser primeira pessoa do plural no Português do Brasil e as variantes seriam nós vs a gente.

Tendo estabelecidas as variantes, seria necessário considerar as variáveis envolvidas que poderiam ser de ordem social e lingüística, os chamados grupos de fatores. Após o recolhimento e codificação dos dados de acordo com os grupos estabelecidos anteriormente, é realizada uma análise quantitativa com a utilização de um 
programa estatístico - Varbrul $^{5}$ - que deve apontar, por meio de pesos relativos, a influência de determinado grupo de fatores sob o fenômeno estudado. É possível dizer que se tornam comuns títulos como "A Variável $X$ no dialeto $Y$ ".

De maneira geral, entre os fatores lingüísticos considerados, essas análises centram-se no nível frasal (considerando fatores do nível fonético/fonológico, morfológico e sintático) ou textual, o que fica marcado ao considerar instâncias discursivas como processos de status informacional, aspectos relacionados à coesão textual e contraste (BRAGA, 2003), ou seja, não considerando o sujeito produtor dos enunciados, sendo que este fica reduzido dentro dos fatores sociais em que é encaixado.

Levando-se em consideração as pontuações acima, verifica-se que o projeto variacionista não poderia dar conta de responder às questões desta dissertação, já que a análise quantitativa abandona as relações estabelecidas entre linguagem e sujeito para se trabalhar com pesos relativos de grupos de fatores.

Por um lado, a teoria variacionista contribuiu construindo uma reflexão mais refinada das categorias sociais e lingüísticas, apontando para a dificuldade de estabelecer limites entre as categorias baseadas em aspectos biológicos como homem e mulher (em oposição a gênero) ou raça (em oposição a etnia). Por outro lado, entretanto, o seu alvo de análise é a língua enquanto sistema, mesmo que entendida como sistema heterogêneo, e não os processos envolvidos na constituição dos enunciados, objeto do estudo que apresento. Por essa razão, meu trabalho exige mais ênfase nas contribuições da Análise do Discurso.

Para realizar uma aproximação entre Análise do Discurso e as análises que pretendo realizar nesta dissertação, recorro, portanto, ao trabalho de Schlieben-Lange (1993) que estabelece relações entre as representações associadas a uma língua e a produção linguíística. A autora parte dos trabalhos de Coseriu (1979) para pensar outros exercícios que compõem o "falar" que ultrapassam o modus operanti da língua histórica. Assim, a aluna de Coseriu reorganiza a divisão sistema, norma e fala em fala, língua histórica e texto.

Essa reorganização permite à autora aproximar-se das atividades e dos efeitos dessas nas técnicas do falar. É nesta direção que Schlieben-Lange traça considerações a respeito da alteração da atividade lingüística causada por uma consciência teórica que passa a ditar uma norma-de-dever.

\footnotetext{
${ }^{5}$ Trata-se de um software que realiza cálculos estatísticos a partir da codificação dos dados lingüísticos.
} 
Para a autora, o "normal" não pode ser considerado somente no estatuto do ser, mas também do dever. É neste momento de sua reflexão que lança mão de dois conceitos: norma-de-ser e norma-de-dever.

A primeira norma é destinada para a produção dos falantes e a segunda é tomada como "exemplar" e, portanto, causa efeito nas atividades também. Dessa forma, a autora considera tanto as influências que as atividades exercem sobre uma consciência ingênua e teórica quanto as influências dessas consciências na atividade lingüística.

\begin{abstract}
Há, de um lado, um saber sobre a língua, que afeta tanto as unidades de uma determinada língua como também as suas possibilidades de uso. Os falantes de uma língua sabem muito sobre ela e são capazes de explicitar esse saber até um determinado grau: eles podem dizer quais são os elementos que fazem parte de sua língua e quais são estranhos, podem dizer quais são os elementos antigos e quais são surpreendentes e novos baseando-se num saber sobre as possibilidades sistemáticas de sua língua e sobre aquilo que normalmente é realizada nela. (SCHLIBEN-LANGE, 1993:94-95)
\end{abstract}

Parece-me que a linha de pesquisa defendida por Schlieben-Lange pode constituir uma boa entrada para desenvolver articulações entre a sociolingüística e a AD. Ao abrir espaço para considerar as influências das diversas atividades sobre o falar, a autora favorece uma investigação que busca considerar as relações entre aquele que fala e a língua, juntamente com o conhecimento que esse falante manipula em sua ação.

O fato de que as línguas são objetos de discursos quotidianos que podem ser tanto descritivos quanto avaliativos foi reconhecido como campo central da pesquisa sociolingüística. Esses discursos e sua fossilização em clichês e estereótipos parecem ser importantes para a prática lingüística e não podem ser subestimados como ponto de partida para intervenções políticolingüísticas. (op.cit.: 94-93)

Finalmente, gostaria de destacar o trabalho de Leite (1999) que toma como objeto de estudo o discurso metalingüístico representativo de várias etapas históricas das discussões em torno da língua portuguesa no Brasil. Por meio da análise desse discurso, a autora persegue o que nomeia de purismo lingüístico, atitude que pretende preservar uma determinada norma.

Ao demonstrar que uma atitude de purismo lingüístico continua a existir nos discursos metalingüísticos mais atuais, Leite (1999) abre caminhos para pesquisas que pretendem investir nas influências que os homens exercem sobre a língua na forma de ações. 
Os trabalhos de Schlieben-Lange (1993) e Leite (1999) colocam em jogo em suas análises elementos que não limitam a superficialidade do enunciado, posição, como já afirmado anteriormente, central para a $\mathrm{AD}$ que tem como conceito básico as condições de produção como processo de constituição do discurso.

\section{O MODELO DA ANÁLISE DO DISCURSO}

A principal razão da adoção de uma perspectiva discursiva para a elaboração de respostas às perguntas apresentadas nesta dissertação está relacionada com o fato de a análise considerar, por meio da materialidade lingüística do enunciado, a descrição de elementos exteriores aos elementos da superfície.

Pêcheux (1969) inicia seu texto distinguindo modos de leitura antes e após Saussure para distinguir uma análise de conteúdo e a teoria do discurso. O autor resume os objetivos dos trabalhos com textos antes de Saussure com as seguintes questões relacionadas à compreensão do texto ou à gramática;

Compreensão do Texto: De que fala este texto?

Quais as principais idéias contidas no texto?

Gramática: Está de conformidade com as regras?

Quais as regras próprias a este texto?

A esta concepção que buscava uma função para o texto, apoiado pela teoria saussuriana de sistema, Pêcheux vai elaborar uma teoria do discurso que visa a descrever um funcionamento. Compreender a linguagem como funcionamento é o que permite proceder a análises que superem o nível da frase. Para Pêcheux:

\footnotetext{
Fenômenos lingüísticos de dimensão superior à frase podem efetivamente ser concebidos como um funcionamento, mas com a condição de acrescentar imediatamente que este funcionamento não é integralmente lingüístico, no sentido atual desses termos e que não podemos defini-lo senão em referência ao mecanismo de colocação dos protagonistas e do objeto de discurso, mecanismo que chamamos "condições de produção do discurso. (op.cit.: 78)
}

Nessa linha de reflexão, Pêcheux irá propor uma teoria dos efeitos de sentido que leva em consideração as condições de produção do discurso, partindo da hipótese de 
que estas condições ( $\mathrm{A}$ e $\mathrm{B}$, lugares da estrutura social, passíveis de descrição) fazem parte do processo discursivo no que nomeia de formações imaginárias. Pêcheux estabelecerá, por meio dessas formações imaginárias, os lugares em que cada interlocutor atribui a si e ao outro que podem ser indiciados pelas perguntas: Quem sou eu para lhe falar assim? Quem é ele para que eu lhe fale assim? Quem sou eu para que ele me fale assim? Quem é ele para que me fale assim? (op. cit.:.83).

Além dessas formações imaginárias, Pêcheux acrescenta mais duas questões em relação ao referente para considerar o ponto de vista A e B em relação ao referente: $D e$ que lhe falo eu? e De que ele me fala? (op. cit.: 84)

Levar em conta esses pressupostos teóricos permite avançar em direção a uma análise que considera as condições de produção e, desta forma, inclui os protagonistas, em um movimento contrário às abordagens empreendidas pela sociolingüística. É essa mesma direção que é salientada no trabalho de Osakabe (1979) que, ao abordar as formações imaginárias como processo constitutivo do discurso, inclui a relação atuacional e pragmática estabelecida entre A e B a partir da pergunta: $O$ que A pretende falando dessa forma?, pergunta que é desmembrada em duas outras: $O$ que A pretende de B falando dessa forma? e $O$ que A pretende de A falando dessa forma? (op. cit.:55).

Nesse momento de sua elaboração, Pêcheux (1969) apoiava-se no desenvolvimento da lingüística para criar uma teoria do discurso que se realizaria por meio de etapas da análise sintática de enunciados elementares até chegar à fase interpretativa de seqüência do corpus. Pressupunha-se o estabelecimento de um corpus em condições de produção homogêneas e estáveis. Na avaliação do próprio autor:

AD-1 é um procedimento por etapa, com ordem fixa, restrita teórica e metodologicamente a um começo e um fim predeterminados, e trabalhando num espaço em que as "máquinas" discursivas constituem unidades justapostas (PÊCHEUX, 1983b: 313).

Os pontos citados acima serão re-elaborados nos trabalhos posteriores do autor (em especial Pêcheux 1975, 1983a e 1983b). No entanto, a posição teórica pressuposta pelas formações imaginárias que quebra a noção de univocidade entre sujeito e linguagem será mantida durante o desenvolvimento de sua teoria (PÊCHEUX, 1983b:311).

No trabalho Semântica e Discurso (1975), o principal deslocamento está na incorporação da noção de formação discursiva dos trabalhos de Foucault e a elaboração 
da noção de interdiscurso. Em oposição a uma maquinaria discursiva fechada, essa noção aponta para a relação estabelecida entre a formação discursiva do enunciado com outras formações discursivas. Nesse momento, as principais alterações foram sentidas na constituição do corpus, que passou da sistematização de unidades justaposta à consideração das relações de forças internas.

Em seus últimos trabalhos (1983a e 1983b), a noção de maquinaria auto determinada (a estrutura a qual o sujeito estava submetido) é deslocada para a consideração do acontecimento (ponto em que o enunciado rompe com a discursividade na qual estava inserido, possibilitando o estabelecimento de uma nova rede de dizeres).

\begin{abstract}
A conseqüência do que precede é que toda descrição - quer se trate da descrição de objetos ou de acontecimentos ou de um arranjo discursivotextual não muda nada, a partir do momento em que nos prendemos firmemente ao fato de que "não há metalinguagem"- está intrinsecamente suscetível de tornar-se outro, diferente de si mesmo, se deslocar discursivamente de seu sentido para derivar para um outro (a não ser que a proibição da interpretação própria ao logicamente estável se exerça sobre ele explicitamente). Todo enunciado, toda sequiência de enunciados é, pois, linguisticamente descritível como uma série (léxico-sintaticamente determinada) de pontos de deriva possíveis, oferecendo lugar a interpretação. É nesse espaço que pretende trabalhar a análise de discurso. (op.cit.: 53)
\end{abstract}

As elaborações de Pêcheux em torno da teoria do discurso trazem implicações diretas a uma pesquisa que pretende proceder à análise de enunciados nos quais os sujeitos realizam declarações acerca das identidades étnicas e lingüísticas ${ }^{6}$. A principal consiste na impossibilidade de tomar os enunciados como portadores dos significados atribuídos a essas etnias e, por conseqüência, a impossibilidade de determinar a identidade seja dos sujeitos, seja da língua.

Nesta pesquisa, abandono, portanto, a tentativa de fixar um limite entre o que é a língua portuguesa e a língua japonesa, como na vertente estruturalista empregada nas pesquisas sociolingüísticas, para avançar no empreendimento das ações realizadas na linguagem que tendem a naturalizar os discursos transformando-os em marcadores de identidade. Ao escolher este caminho, abro mão de realizar afirmações a respeito da língua ou da identidade do falante, no sentido existencialista, para incidir sobre os mecanismos que condicionam a produção dos enunciados que analisarei.

\footnotetext{
${ }^{6}$ Cumpre dizer que as considerações entre a concepção de linguagem adotada e o conceito de identidade étnica será o tema da introdução do capítulo um, já o debate acerca da identidade lingüística ocorrerá no capítulo 2.
} 


\section{PROCEDIMENTOS DE ANÁLISE E CONSTITUIÇÃO DO CORPUS}

Os procedimentos de análise e a constituição do corpus foram realizados levando em consideração a articulação entre a AD (em especial, Pêcheux 1983a e 1983b) e a História Cultural tal como definida nos trabalhos de Chartier (1990, 1994). É no momento em que a $\mathrm{AD}$ abandona a tentativa de estabelecer um corpus homogêneo, a partir do qual se poderia depreender os processos de constituição de um discurso, que a articulação com os trabalhos desenvolvidos por Chartier torna-se pertinente para esse trabalho.

Em seus estudos, o autor tem se dedicado a compreender o modo como os homens lidaram com a diversidade de textos que o livro manuscrito e posteriormente impresso colocou em circulação, especialmente, entre o fim da Idade Média e o Século XVIII. Suas pesquisas interessam-me na medida em que apontam caminhos a percorrer para compreender os mecanismos envolvidos na construção de uma determinada realidade social, procurando identificar os usos que se tem feito dos modos de transmissão e das representações em que o conhecimento está associado. Para o historiador:

A história cultural, tal como a entendemos, tem por principal objecto identificar o modo como em diferentes lugares e momentos uma determinada realidade social é construída, pensada, dada a ler. (CHARTIER, 1990: 16-17)

Para realizar tal trabalho, Chartier elabora, durante o desenvolvimento de suas pesquisas, três conceitos que permitem a aproximação da realidade social, a saber: representação, prática e apropriação.

A definição de história cultural pode, nesse contexto, encontrar-se alterada. Por um lado, é preciso pensá-la como a análise do trabalho de representação, isto é, das classificações e das exclusões que constituem, na sua diferença radical, as configurações sociais e conceptuais próprias de um tempo ou de um espaço. As estruturas do mundo social não são um dado objectivo, tal como o não são as categorias intelectuais e psicológicas: todas elas são historicamente produzidas pelas práticas articuladas (políticas, sociais, discursivas) que constroem as suas figuras. São estas demarcações, e os esquemas que as modelam, que constituem o objeto de uma história cultural levada a repensar completamente a relação tradicionalmente postulada entre o social, identificado com um real bem real, existindo por si 
próprio, e as representações, supostas como reflectindo-o ou dele se desviando.

Por outro lado, esta história deve ser entendida como o estudo dos processos com os quais se constrói um sentido. Rompendo com a antiga idéia que dotava os textos e as obras de um sentido intrínseco, absoluto, único - o qual a crítica tinha obrigação de identificar -, dirige-se às práticas que pluralmente, contraditoriamente, dão significado ao mundo. (op.cit.:17 grifos meus )

O desenvolvimento do trabalho de Chartier torna-se importante para a realização de meu trabalho por três motivos principais:

a- auxilia a constituição de um corpus que busque salientar as representações de uma determinada realidade social, no meu caso, das identidades étnicas e lingüísticas associadas aos imigrantes japoneses e seus descendentes;

b- indicia a importância das relações que os sujeitos estabelecem com as representações que circulam no momento em que realizam declarações acerca das identidades étnicas e lingüísticas desse grupo específico; e

c- aponta para a necessidade de investigar os modos pelos quais os sujeitos se apropriam das representações que circulam como modo de agir sobre a constituição de sentidos.

Nas palavras de Chartier:

No ponto de articulação entre o mundo do texto e o mundo do sujeito colocase necessariamente uma teoria da leitura capaz de compreender a apropriação dos discursos, isto é, a maneira como estes afectam o leitor e o conduzem a uma nova norma de compreensão de si próprio e do mundo. (op.cit.: 24)

Levando em conta as considerações de Chartier, busquei constituir um corpus com enunciados produzidos a partir de lugares enunciativos diferentes, possibilitando uma investigação da circulação dessas representações dentro da sociedade. Dessa forma, ao analisar um enunciado produzido durante uma entrevista, pude perceber uma negociação com as representações veiculadas em outras formas de circulação, como a mídia, por exemplo. 


\section{AS CONDIÇÕES DE PRODUÇÃO DO CORPUS}

Como mencionado acima, os enunciados que foram submetidos à análise nesse trabalho foram recortados (ORLANDI, 1984) de vários contextos diferentes. Esta seção é dedicada à apresentação e a justificativa da presença desses materiais no corpus composto para essa dissertação. Assim, o corpus é constituído por:

a- Trabalhos da área de história representados por A negociação da identidade nacional, de Jeffery Lesser (2001), e Matizes do Amarelo - a gênese dos discursos sobre os orientais, de Rogério Dezem (2003).

Os trabalhos produzidos pela área de história desempenharam dois papéis. Primeiro serviram como parte da bibliografia do trabalho, uma vez que os objetos de pesquisa dos dois historiadores constituem temáticas importantes para o desenvolvimento de minha dissertação. Lesser (2001) tem por objeto de investigação a construção da identidade de imigrantes no Brasil e dedica mais da metade de seu livro à comunidade nipo-brasileira. Dezem (2003), por sua vez, realiza uma busca dos primeiros textos escritos sobre os orientais nas revistas de grande circulação da época. A apresentação da leitura dessas duas obras é o que constitui o panorama histórico apresentado no primeiro capítulo desta dissertação.

O segundo papel desempenhado por esses trabalhos está relacionado com a possibilidade de realizar uma análise dos enunciados das fontes que compõem as duas pesquisas históricas. Ambos os trabalhos apresentam uma grande quantidade de documentos utilizados como comprovações para suas interpretações, no entanto, não realizam uma análise lingüística desses documentos. Também no capítulo um, apresento análises de vários recortes feitos a partir da documentação incorporada nos trabalhos de Lesser (2001) e Dezem (2003).

b- Enunciados produzidos pela mídia, representada pela edição número 49 do Ano 40 da revista Veja, edição dedicada à comemoração dos 100 anos da imigração japonesa.

A edição, que possui 202 páginas, dedica a capa, a seção carta ao leitor e mais sete matérias que dividem 45 páginas ao tema da imigração japonesa, além 
dessas partes ainda pode ser encontrada uma imagem de Tóquio ilustrando o sumário e uma propaganda do banco Real dedicada a divulgar produtos para a comunidade nipo-brasileira. As sete matérias distribuídas entre as páginas 78 e 140 são: 1) Os 100 anos da imigração japonesa; 2) A história das gerações; 3) Os que vieram, os que ficaram e os que voltaram; 4) Imagens do Japão; 5) As mulheres que dizem não; 6) Velhice dourada; e 7) Dekasseguis:o refluxo migratório.

c- Enunciados produzidos pelas instituições oficiais da comunidade nipo-brasileira representadas pelos textos publicados no livro O Futuro da Comunidade Nikkey, organizado por Masato Ninomiya como resultado do simpósio de comemoração dos 85 anos da imigração japonesa no Brasil, publicado três anos depois, em 1996.

Os enunciados produzidos nessa categoria tornam-se importantes para pensar as representações associadas à identidade dos imigrantes e seus descendentes por terem sido produzidas por pessoas que exercem, ou participam, de entidades ligadas à transmissão e preservação da cultura japonesa. Acrescenta-se, ainda, o fato de tais enunciados serem veiculados em forma de livro, o que permite uma circulação diferenciada e um investimento simbólico mais próximo à produção de conhecimento.

d- Enunciados produzidos por descendentes de imigrantes japoneses

Os enunciados produzidos por descendentes de imigrantes japoneses ocupam um espaço privilegiado para a análise das representações associadas à identidade étnica dos japoneses, uma vez que, na declaração de suas próprias identidades, a negociação com as representações das identidades relacionadas às identidades étnicas brasileira e japonesa torna-se saliente.

Por esse motivo foram recolhidos enunciados de duas fontes diferentes, a saber: enunciados recolhidos a partir de sites de relacionamentos da internet e por meio de entrevistas realizadas com descendentes de imigrantes japoneses. 
1- Enunciados recolhidos da internet

Os enunciados foram recolhidos do site de relacionamentos Orkut. Trata-se de um site que possibilita a criação de uma página pessoal nomeada de perfil. A partir dessa página, é possível ao usuário disponibilizar as informações que julgar pertinente e inserir outros perfis no espaço nomeado de "meus amigos". Além da possibilidade de estabelecer comunicação com os perfis das pessoas inseridas no perfil pessoal, o site oferece a possibilidade de criar páginas que visam a reunir perfis em torno de temas, são as chamadas comunidades virtuais.

É dessa segunda ferramenta que retiramos enunciados produzidos pelos descendentes de imigrantes japoneses. As comunidades são páginas que possuem um título ligado à temática que é descrita na seção de apresentação e também permitem a interação dos participantes por meio da ferramenta tópico de discussão. Os tópicos de discussão podem ser criados por qualquer participante da comunidade e debatidos pelos outros membros.

A partir da ferramenta de busca disponibilizada pelo site, encontrei duas comunidades a partir das quais depreendi representações associadas à identidade étnica e lingüística associadas ao imigrante japonês e seus descentes. Refiro-me às comunidades intituladas Sou Japa com (mtu) Orgulhu (Anexo I) e Eu falo batyanês (Anexo II).

Da primeira comunidade, selecionei sua descrição, que apresenta as razões para integrar o grupo e vinte enunciados produzidos no tópico vcs nunca foram nihongin!, no período de 12/05/2005 a 25/12/2005 (Anexo III). Já da segunda comunidade, além da descrição, foram tomados 204 enunciados produzidos no tópico intitulado palavras engraçadas da batyan, no período entre 14/11/2006 e 14/12/2008 (Anexo IV).

As declarações acerca das identidades étnica e lingüística retiradas dessas comunidades são representativas por terem sido produzidas por descendentes de imigrantes japoneses, característica que possibilita depreender o movimento realizado por eles em relação às representações circuladas em outros espaços.

Os dados foram transpostos para o trabalho sem nenhum ajuste ortográfico, no entanto, a análise, por ter como foco as representações produzidas por esses enunciados, não buscou sistematizar as formas gráficas utilizadas nesse contexto de produção. 


\section{2- Entrevistas}

Também realizei entrevistas com descendentes de imigrantes japoneses como forma de recolher enunciados que buscassem delimitar as identidades étnica e lingüística desse grupo. Os entrevistados tiveram conhecimento prévio do tema geral da pesquisa e o entrevistador realizou intervenções nas respostas, ou seja, abdiquei da neutralidade buscada nos trabalhos de sociolingüística.

Foram realizadas quatro entrevistas das quais escolhi duas para compor o corpus da dissertação. Ambas foram feitas com pessoas pertencentes à terceira geração, ou seja, com netos de imigrantes japoneses e, apesar de não ter seguido um roteiro rígido, procurei seguir o seguinte percurso: história familiar, relação com os avós, definição da própria identidade e relação com a língua japonesa.

A primeira entrevista foi realizada com uma mulher de 23 anos, estudante universitária ${ }^{7}$. É neta de imigrantes japoneses em relação aos avós paternos e maternos e participa da comunidade virtual Eu falo batyanês (Anexo V). O informante 2 também participa da comunidade, tem 22 anos e é estudante universitário. Seus avós paternos são imigrantes japoneses e os avós maternos nasceram no Brasil (Anexo VI).

A transcrição das entrevistas seguiu as normas, expostas em Preti (1993:13), estabelecidas pelo Projeto de Estudo da Norma Urbana Culta de São Paulo, como exemplifica o quadro a seguir:

\begin{tabular}{|c|c|c|}
\hline OCORRÊNCIAS & SINAIS & EXEMPLIFICAÇÃO* \\
\hline $\begin{array}{l}\text { Incompreensão de palavras } \\
\text { ou segmentos }\end{array}$ & ( ) & $\begin{array}{l}\text { do nível de renda...( ) } \\
\text { nível de renda nominal... }\end{array}$ \\
\hline Hipótese do que se ouviu & (hipótese) & $\begin{array}{l}\text { (estou) meio preocupado (com } \\
\text { o gravador) }\end{array}$ \\
\hline $\begin{array}{l}\text { Truncamento (havendo } \\
\text { homografia, usa-se acento } \\
\text { indicativo da tônica e/ou } \\
\text { timbre) }\end{array}$ & l & e comé/ e reinicia \\
\hline Entoação enfática & Maiúscula & $\begin{array}{l}\text { porque as pessoas reTÊM } \\
\text { moeda }\end{array}$ \\
\hline $\begin{array}{l}\text { Prolongamento de vogal e } \\
\text { consoante (como } \mathrm{s}, \mathrm{r} \text { ) }\end{array}$ & $\begin{array}{c}:: \text { podendo aumentar para }:: .: \\
\text { ou mais }\end{array}$ & $\begin{array}{l}\text { ao emprestarem os... éh::.: ...o } \\
\text { dinheiro }\end{array}$ \\
\hline
\end{tabular}

\footnotetext{
${ }^{7}$ A informante 1 cursou Letras (português/ japonês) e atualmente é aluna do curso de pedagogia.
} 


\begin{tabular}{|c|c|c|}
\hline Silabação & - & por motivo tran-sa-ção \\
\hline Interrogação & $?$ & eo Banco... Central... certo? \\
\hline Qualquer pausa & $\cdots$ & $\begin{array}{l}\text { são três motivos... ou três } \\
\text { razões... que fazem com que } \\
\text { se retenha moeda... existe } \\
\text { uma... retenção }\end{array}$ \\
\hline $\begin{array}{l}\text { Comentários descritivos do } \\
\text { transcritor }\end{array}$ & ((minúsculas)) & $(($ tossiu $))$ \\
\hline $\begin{array}{l}\text { Comentários que quebram a } \\
\text { seqüência temática da } \\
\text { exposição; desvio temático }\end{array}$ & -- -- & $\begin{array}{l}\text {... a demanda de moeda -- } \\
\text { vamos dar essa notação -- } \\
\text { demanda de moeda por } \\
\text { motivo }\end{array}$ \\
\hline $\begin{array}{l}\text { Superposição, } \\
\text { simultaneidade de vozes }\end{array}$ & $\{$ ligando as linhas & $\begin{array}{l}\text { A. na }\{\text { casa da sua irmã } \\
\text { B. sexta-feira? } \\
\text { A. fizeram \{ lá... } \\
\text { B. cozinharam lá? }\end{array}$ \\
\hline $\begin{array}{l}\text { Indicação de que a fala foi } \\
\text { tomada ou interrompida em } \\
\text { determinado ponto. Não no } \\
\text { seu início, por exemplo. }\end{array}$ & $(\ldots)$ & (...) nós vimos que existem... \\
\hline $\begin{array}{l}\text { Citações literais ou leituras de } \\
\text { textos, durante a gravação }\end{array}$ & " " & $\begin{array}{l}\text { Pedro Lima... ah escreve na } \\
\text { ocasião... "O cinema falado } \\
\text { em língua estrangeira não } \\
\text { precisa de nenhuma baRREIra } \\
\text { entre nós"... }\end{array}$ \\
\hline
\end{tabular}

* Exemplos retirados dos inquéritos NURC/SP No. 338 EF e 331 D $^{2}$.

\section{Observações:}

1. Iniciais maiúsculas: só para nomes próprios ou para siglas (USP etc.)

2. Fáticos: $a h$, éh, eh, ahn, ehn, uhn, tá (não por está: tá? você está brava?)

3. Nomes de obras ou nomes comuns estrangeiros são grifados.

4. Números: por extenso.

5. Não se indica o ponto de exclamação (frase exclamativa).

6. Não se anota o cadenciamento da frase.

7. Podem-se combinar sinais. Por exemplo: oh::.... (alongamento e pausa).

8. Não se utilizam sinais de pausa, típicos da língua escrita, como ponto-e-vírgula, ponto final, dois pontos, vírgula. As reticências marcam qualquer tipo de pausa, conforme referido na Introdução. 


\title{
APRESENTAÇÃO E ANÁLISE DE DADOS
}

A partir da leitura de todo o material que compõe o corpus desta dissertação foram procedidos recortes (ORLANDI, 1984) a partir dos quais se realizou a análise dos dados. Orlandi contrapõe a metodologia empregada pela lingüística estrutural, que consiste em um processo de segmentação (da frase às relações sintáticas, das palavras aos morfemas etc), com o modo de apresentação da $\mathrm{AD}$, que consiste em realizar um recorte de uma seqüência discursiva a partir da qual é possível depreender o funcionamento do discurso.

A apresentação e análise de dados seguem as recomendações de Pêcheux (1983a), que alerta para a necessidade de se alternar os movimentos de descrição e interpretação dos dados. A interpretação como é aqui entendida aponta como gesto a necessidade de ligar língua e história na produção dos sentidos.

\begin{abstract}
A posição de trabalho que aqui evoco em referência à análise de discurso não supõe de forma alguma a possibilidade de algum cálculo dos deslocamentos de filiação e das condições de felicidade ou de infelicidade evenemenciais. Ela supõe somente que, através das descrições regulares de montagens discursivas, se possa detectar os momentos de interpretações enquanto atos que surgem como tomadas de posição, reconhecidas como tais, isto é, como efeitos de identificação assumidos e não negados. (op. cit.: 57)
\end{abstract}

É essa perspectiva que adotarei para analisar os enunciados que, apesar de terem sido produzidos em contextos e por sujeitos diferentes, têm um traço que os perpassa: a tentativa de delimitar os significados atribuídos às identidades étnica e linguística dos imigrantes japoneses e seus descendentes.

Acredito que nesse momento vale a pena retomar as questões que norteiam a redação desse trabalho:

a- Quais operações discursivas são utilizadas pelos sujeitos ao realizarem afirmações sobre a identidade étnica e lingüística de um grupo específico?

c- Quais são as implicações dessas operações discursivas sobre a produção dos enunciados? 
Para respondê-las, realizei um recorte que permitiu estruturar a dissertação da seguinte forma:

No capítulo um, Traços da representação do "japonês": um estudo das declarações sobre a identidade étnica, inicio a discussão em torno do conceito de identidade e o modo como este é compreendido em meu trabalho. Além disso, realizo uma análise dos enunciados que buscam delimitar a identidade étnica associada ao "japonês".

Juntamente com o capítulo um, o capítulo dois, As representações da linguagem: estudo das declarações sobre a língua, tem como objetivo responder à primeira pergunta de pesquisa desta dissertação. Neste capítulo, dedico-me à análise dos enunciados produzidos por descendentes de imigrantes japoneses que buscam caracterizar a linguagem utilizada por seus ascendentes.

Apesar dos dois capítulos já apontarem para algumas implicações que as representações das identidades étnica e lingüística podem ter com a produção dos enunciados, o capítulo três é reservado para análise de dois enunciados em que as implicações se tornam mais salientes, o que permitirá produzir uma resposta mais precisa à segunda pergunta deste trabalho.

Finalmente, apresento as considerações finais do trabalho estabelecendo algumas consequiências que os procedimentos analisados podem ter para a produção lingüística e também com relação às declarações das identidades étnicas e lingüísticas. 


\section{TRAÇOS DAS REPRESENTAÇÕES DO "JAPONÊS": UM ESTUDO DAS DECLARAÇÕES SOBRE A IDENTIDADE ÉTNICA}

Neste capítulo, procurarei depreender alguns traços que constituem as representações associadas à identidade da comunidade nipo-brasileira a partir de enunciados que buscam determinar o que é ser japonês e as representações ligadas a esta identidade étnica.

Para estabelecer o conceito de identidade, partirei das discussões que embasam os estudos da sociolingüística para depois ampliar essa noção com o conceito de identificação da teoria psicanalítica. A partir de uma noção adequada à abordagem enunciativa, buscarei as representações que constituem a identidade da comunidade japonesa considerando as seguintes condições de produção:

a- Trabalhos da área de história, representados por Lesser (2001) e Dezem (2003);

b- A mídia, representada pela edição número 49 do Ano 40 da revista Veja, edição dedicada à comemoração dos cem anos da imigração japonesa;

c- Instituições oficiais da comunidade nipo-brasileira, representadas pelos textos publicados no livro O Futuro da Comunidade Nikkey, organizado por Masato Ninomiya como resultado do simpósio de comemoração dos oitenta e cinco anos da imigração japonesa no Brasil, publicado três anos depois, em mil novecentos e noventa e seis.

d- Enunciados produzidos por descendentes de imigrantes japoneses em tópicos de discussão na internet e em entrevistas. 


\subsection{A IDENTIDADE E OS TRABALHOS DA SOCIOLINGÜÍSTICA LABOVIANA}

Inicio as discussões a respeito do conceito de identidade pelos trabalhos da sociolinguí́stica laboviana, uma vez que esses estudos consideram a linguagem como um sistema de regras heterogêneo, que possibilita uma aproximação com os fatores envolvidos na produção lingüística. Os trabalhos realizados sob o escopo dessa perspectiva vêem se dedicando ao estudo das relações entre fatores sociais e lingüísticos e o (des)favorecimento da produção de uma determinada variante.

Um dos avanços produzidos pelas pesquisas desenvolvidas na área é o refinamento das categorias utilizadas para análise que apontam para a necessidade de se criar categorias que sejam mais eficazes do que as grandes construções sociais como sexo, classe social, raça etc (CHAMBERS, 2006). Entre os resultados desse refinamento teórico está a utilização do conceito de identidade, visto como uma negociação ativa da relação do indivíduo com grandes construções sociais.

Mendoza-Denton (2006) distingue três abordagens nas pesquisas que utilizaram questões relacionadas à identidade como uma categoria de análise no estudo de variáveis lingüísticas.

1- identidade baseada em categoria sociológica;

2- identidade baseada em prática; e

3- variação baseada em prática.

$\mathrm{Na}$ primeira categoria, identidade baseada em categoria sociológica, a autora agrupa os trabalhos que levaram em consideração a estratificação de uma determinada população em categorias sociológicas como região, sexo, ocupação, classe social etc. Um exemplo de trabalho nessa categoria pode ser encontrado em Labov (1994), trabalho em que utiliza como um grupo de fator relevante o critério "manutenção das casas dos participantes" nas pesquisas sobre variação e mudança lingüística na Philadelphia.

$\mathrm{Na}$ segunda categoria, Identidade baseada em Práticas, estão reunidos os estudos que buscam criar grupos de fatores que não estão necessariamente relacionados com as categorias designadas ou reivindicadas pela sociedade, mas por uma identidade realizada na prática em conjunto de atividades particulares. Coelho (2006), por 
exemplo, lista como fator relevante "freqüentar a praça pública da comunidade", ao investigar o pronome de primeira pessoa do plural e a marcação do plural em verbos na comunidade da Brasilândia, periferia da cidade de São Paulo.

$\mathrm{Na}$ esteira da segunda abordagem chega-se à determinação de um terceiro grupo, Variação baseada em prática, em que estão reunidos os trabalhos que consideram que as identidades dos falantes não são dados determinados, mas estão abertas à transformação impulsionada pelo contexto. A própria autora, Mendoza-Denton (1999), ao examinar a fala de meninas de gang latinas (descendentes de mexicanos) considera fatores como maquiagem, vestimenta e entonação para sua análise.

Nessa direção, a identidade não é um elemento dado a priori, em que o falante pode ser encaixado com facilidade. Ela deixa de pertencer ao campo do essencialismo (em que se busca a essência de ser "x") para considerar os vários traços que se combinam durante a interação para formar uma identidade que é, por definição, multifacetada.

É o desenvolvimento do conceito de identidade como uma categoria que deve ser depreendida a partir da interação e das práticas das comunidades que aproxima os trabalhos da sociolingüística com o conceito de identidade étnica. Fought (2006) afirma que o primeiro ponto importante ao tratar da questão da etnia nas pesquisas variacionistas é diferenciar raça de etnia.

Para estabelecer a diferença, a autora faz um paralelo com as categorias sexo versus gênero. Enquanto a primeira está ligada ao biológico, a segunda se relaciona com a construção de uma identidade sexual socialmente estabelecida. Do mesmo modo, o conceito de etnia não está ligado ao que o falante é, mas, sim, ao que ele faz. No entanto, diferentemente de sexo, categoria na qual os indivíduos podem ser agrupados biologicamente em uma das duas categorias básicas, a categoria de raça teria sido historicamente construída e, por esta razão, seria muito difícil delimitá-la cientificamente.

Levando em consideração essa dificuldade para se delimitar o que constitui um grupo étnico, Edwards (1994) pontua a importância de um sentimento de grupo que deriva de fronteiras comuns reais ou construídas como língua, raça ou religião.

Ethnic identity is allegiance to a group - large or small, socially dominant or subordinate - with which one has ancestral links. There is no necessity for a continuation, over generations, of the same socialization or cultural patterns, but some sense of a group boundary must persist. This can be sustained by shared objective characteristics (language, religion, etc.) or by more 
subjective contributions to a sense of 'groupness', or by some combination of both. Symbolic or subjective attachements must relate, at however distant, a remove to an observably real past ${ }^{8}$ (EDWARDS, 1994: 128)

As discussões apresentadas acima permitem uma aproximação do conceito de identidade adotado neste trabalho na medida em que postula que a identidade é uma construção e, ao mesmo tempo, uma categoria pré-existente. No entanto, a abordagem para a depreensão dos traços que constituem uma identidade não se aproxima da opção teórica presente na introdução desta dissertação.

Nas pesquisas sociolingüísticas, opta-se preferencialmente por uma abordagem etnográfica na qual o pesquisador insere-se na comunidade e busca compreender as relações estabelecidas por meio da descrição dos hábitos e índices que apontam para a adoção de uma determinada identidade.

Trata-se de uma perspectiva que dá relevância para a língua em uso e que procura depreender uma identidade estável, mesmo considerando que a identidade possa ser moldada na interação e de acordo com o contexto. De maneira geral, busca-se identificar em índices os marcadores de uma determinada identidade.

Neste trabalho, busco realizar uma abordagem enunciativa não fazendo nenhuma imersão em uma comunidade nipo-brasileira específica. Assim sendo, tentei caracterizar a identidade dessa comunidade por meio das representações produzidas a partir de diferentes contextos, mas que buscam delineá-la.

Essa opção se justifica pela concepção de linguagem adotada, em especial, por Pêcheux (1975) que postula a não unicidade entre o sujeito e o seu dizer. Nessa perspectiva, o fato de o sujeito se colocar no lugar de quem produz seu dizer é resultado de um processo que é constituído por dois esquecimentos:

a- Esquecimento da instância ideológica: cria a ilusão de que o sujeito é a origem do dizer, que o que diz é novo; e

\footnotetext{
${ }^{8}$ Identidade étnica é a lealdade a um grupo - grande ou pequeno, socialmente dominante ou subordinado - com o qual uma pessoa possui ligação ancestral. Não há a necessidade de continuação de uma mesma socialização ou padrão cultural entre as gerações, mas alguma noção de limite de grupo deve subsistir. Isto pode ser sustentado por características objetivas compartilhadas (língua, religião etc) ou por contribuições mais subjetivas para uma noção de "grupalidade", ou por alguma combinação de ambos. Atributos simbólicos ou subjetivos devem relacionar, de qualquer distância, uma transferência para um passado real observável. (A tradução é minha).
} 
b- Esquecimento da ordem da enunciação: aquilo que se diz pode ser dito de outra maneira, não havendo uma única forma de se enunciar.

Para o autor:

(...) o sentido de uma palavra, de uma expressão, de uma proposição, etc, não existe "em si mesmo" (isto é, em sua relação transparente com a literalidade do significante), mas ao contrário, é determinado pelas posições ideológicas que estão em jogo no processo sócio-histórico no qual as palavras, expressões e proposições são produzidas (isto é, reproduzidas). (PÊCHEUX, 1975:160).

Ao considerarmos essa perspectiva, torna-se inviável a compreensão de que a identidade possa ser entendida como una, mesmo levando em conta um único contexto, uma vez que o equívoco e a ideologia seriam constitutivos da linguagem. Nessa direção, utilizaremos como referência teórica o conceito de identificação tal como trabalhado por Freud e Lacan.

\subsection{A IDENTIFICAÇÃO NA PSICANÁLISE}

A noção de identificação, tal como elaborada pela psicanálise, também aponta para a impossibilidade de se apreender o que é o "si próprio" de uma pessoa. Trata-se de um processo que se inicia desde o nascimento e persiste durante toda a vida de um sujeito. A identidade é composta pelo conjunto de predicativos atribuídos a uma pessoa a partir do qual o sujeito pode se reconhecer, no entanto, esse conjunto varia ao longo da vida, permitindo que a identidade seja reconstruída.

O conceito de identificação é trabalhado ao longo de toda a obra de Freud, desde Estudos sobre a histeria (1895) até em A dissolução do complexo de Édipo (1924). Durante este período, o conceito ainda aparece em Três ensaios sobre a sexualidade (1905), Sobre as teorias da sexualidade das crianças em (1908) e em Psicologia de grupo e análise do ego (1921).

No texto de 1895, Freud pontua, a partir do caso clínico de Elizabeth Von R, uma tendência dos neuróticos em assumir o lugar de sofrimento do outro. Nos textos subseqüentes (1905 e 1908), o conceito aparece relacionado com a constituição da imagem corporal que é construída na relação estabelecida entre o bebê e a mãe, e permite que a criança gradativamente se aproprie de seu próprio corpo na medida em que vai se tornando um ser falante. 
Em Psicologia das massas e análise do eu (1921), Freud investiga o que torna possível que um número grande de pessoas tão diferentes entre si possa formar um grupo no qual todos se tornam parecidos. Nesse contexto, o conceito de identificação é utilizado para explicitar a formação de um laço social. Para o autor, "a identificação é conhecida pela psicanálise como a mais remota expressão de um laço emocional com outra pessoa" (op. cit: 115).

Para Freud, a possibilidade da criação de um laço desse tipo só é possível porque, de forma similar ao bebê que se identifica aos diferentes objetos que constituem o desenvolvimento da pulsão sexual, "um certo número de indivíduos que colocaram um só e mesmo objeto no lugar de seu ideal do ego e, conseqüentemente se identificaram uns com os outros em seus egos" (op. cit.: 147).

Assim, a identidade de um sujeito só pode vir a se constituir pelo processo de identificação, realizado em três estágios. Primeiramente, estabelece-se um laço emocional entre o sujeito e um objeto, tornando o sujeito parte do mundo, posteriormente, passa-se pela introjeção do objeto no ego, que permite a vinculação de um objeto libidinal. Finalmente, o processo se dá pela instalação de um processo identificatório com outros objetos.

Para Freud (1924), a instauração do último estágio da identificação acontece ao final do Complexo de Édipo, momento em que a criança abandona a tentativa de ocupar a posição de objeto de amor dos pais e passa a identificar-se com uma incógnita, um lugar a partir do qual construirá o seu próprio lugar.

A noção de identificação, tal como conceituada por Freud (1895, 1905, 1908, 1921 e 1924), permite-me avançar na noção de identidade que pretendo utilizar, pois, ao considerar a identificação como um processo da ordem do inconsciente, é possível traçar um paralelo com a noção de linguagem escolhida para este trabalho, uma vez que o sujeito não possui o controle da formação de sua identidade.

\subsection{DO CORPO DESPEDAÇADO À UNIDADE DO SIGNFICANTE}

A noção de identificação também aparece como um dos conceitos fundamentais no desenvolvimento da obra de Lacan, que dedica um seminário inteiro entre $1961 \mathrm{e}$ 1962 ao estudo do conceito. Para este trabalho, a elaboração de Lacan interessa principalmente no que se refere à relação que pode ser estabelecida entre identidade e significante. 
Lacan retoma a construção da imagem corporal a partir da relação com o outro. Em seu texto $O$ estádio do espelho como formador da função do eu (1949), o autor vale-se da fascinação que a criança tem com sua imagem refletida no espelho para pontuar que a formação de uma identidade é promovida na exterioridade e não é proveniente do corpo.

Pois a forma total do corpo pela qual o sujeito antecipa numa miragem a maturação de sua potência só lhe é dada como Gestalt, isto é, numa exterioridade em que decerto essa forma é mais constitutiva do que constituída, mas em que, acima de tudo, ela lhe aparece num relevo de estatura que a fixa e numa simetria que a inverte, em oposição à turbulência de movimentos com que ele experimenta animá-la. Assim, essa Gestalt, cuja pregnância deve ser considerada como ligada à espécie, embora em seu motor seja ainda irreconhecível, simboliza, por esses dois aspectos de seu aparecimento, a permanência mental do $[\mathrm{eu}]$, ao mesmo tempo que prefigura sua destinação alienante; é também prenhe das correspondências que unem o $[e u]$ à estátua em que o homem se projeta aos fantasmas que o dominam, ao autômato, enfim, no qual tende a se rematar, numa relação ambígua, o mundo de sua fabricação. (Op. cit.: 98)

O autor coloca o estádio do espelho como uma identificação a partir da qual é possível a construção do "eu" estabelecendo uma relação entre o organismo com a sua realidade. A metáfora do estádio é utilizada para representar a relação de forças que se estabelece entre um corpo despedaçado ${ }^{9}$ (representado pelo interior do estádio) e a imagem deste corpo (representado pela muralha).

[...] o estádio do espelho é um drama cujo impulso interno precipita-se da insuficiência para a antecipação - e que fabrica para o sujeito, apanhado no engodo da identificação espacial, as fantasias que se sucedem desde uma imagem despedaçada do corpo até uma forma de sua totalidade que chamaremos de ortopédica - e para a armadura enfim assumida de uma identidade alienante, que marcará com sua estrutura rígida todo o seu desenvolvimento mental (Ibdem).

É a proposição da identidade como um estádio no qual a imagem do corpo e o corpo despedaçado estão em permanente disputa de forças que distancia este trabalho das noções elencadas nos trabalhos da sociolingüística laboviana apresentadas anteriormente. Portanto, entende-se que uma identidade não é somente fruto do contexto e da interação com o outro e com o ambiente, mas encontra-se relacionada com a

\footnotetext{
${ }^{9}$ A expressão corpo despedaçado é utilizada por Lacan para representar a impossibilidade de uma pessoa ter uma visão completa do próprio corpo, dando atenção para o fato de que a formação da imagem corporal é feita por identificações parciais (FREUD, 1905).
} 
percepção de um corpo fragmentado a partir do qual o bebê pode se perceber como um "eu".

Outro ponto da elaboração de Lacan importante para este trabalho é a relação estabelecida com a linguagem. Para o psicanalista francês, é por meio da linguagem que se estabelece a relação entre o corpo biológico e a realidade. Dessa maneira, a unidade da imagem corporal é proveniente do significante e não do corpo propriamente dito (LACAN, 1961-1962).

Lacan inicia a aula de 06 de dezembro de 1961 estabelecendo a diferença entre igualdade e identidade, afirmando que a proposição $A$ igual a $A$ é diferente de $A$ é $A$, uma vez que um $A$ pode ser igual a outro $A$, mas não pode ser o mesmo. É a partir dessa discussão que o psicanalista apresenta duas mediações possíveis para a identificação: uma mediada pela imagem e outra mediada pelo significante.

A primeira mediação, responsável pela identificação imaginária, caracteriza-se pela presença do objeto no campo de vista perceptivo e estabelece uma identidade pela constituição da imagem deste objeto. A segunda, por sua vez, relaciona-se com a possibilidade de instaurar um vínculo simbólico; o objeto deixa de estar presente para entrar em jogo o significante que, ao invés de conferir unidade, produz uma cisão entre ser e pensamento.

Como exemplo, o autor utiliza a frase Мeu avô é meu avô para diferenciar o primeiro avô vinculado à imagem, ao ser no mundo, e o segundo que está ligado com a posição ocupada pelo primeiro dentro da cadeia de gerações.

Lacan retoma o estudo de Freud em Psicologia de grupos e análise do ego (1921) para distinguir três tipos de identificação que não formariam uma classe por pertencerem a níveis diferentes:

\section{a- Identificação à imagem da devoração assimilante}

Está relacionada com a identificação ao objeto, momento em que o bebê assimila o outro como parte sua, instaurando assim, a possibilidade de vir a se separar do outro para assumir um lugar a partir do qual é possível enunciar "eu”. Instaurase, assim, a possibilidade de um querer subjetivo; 


\section{b- Identificação regressiva}

Está relacionada com a identificação a um significante. Enquanto na primeira identificação o sujeito assimila uma imagem totalizante, nesse nível é escolhido o traço mais saliente do objeto, chamado de traço unário. Instaura-se a possibilidade de produzir uma marca que seja reconhecida; e

\section{c- Identificação ao outro por intermédio do desejo}

Está relacionada com a possibilidade de tomar o outro enquanto sujeito desejante como modelo de estrutura. Enquanto nos outros dois tipos de identificação o objeto se presentifica, seja pela assimilação da imagem ou do traço, nesse o objeto é reintroduzido como falta, promovendo a instauração do movimento de desejo por parte do sujeito.

Compreender a construção de uma identidade levando em consideração os apontamentos elencados anteriormente obriga a discriminar níveis diferentes ${ }^{10} \mathrm{em}$ relação ao processo de identificação. Assim, pode-se considerar que não há correspondência entre aquilo que uma pessoa é enquanto sujeito e os predicados utilizados para sua descrição.

Retomar a elaboração de Freud e Lacan acerca do conceito de identificação permite uma compreensão mais adequada do objetivo deste capítulo, que busca descrever as representações veiculadas em enunciados que delimitam o que é pertencer à comunidade nipo-brasileira. Essa compreensão advém do fato de que o estudo do conceito de identificação, segundo a psicanálise, possibilita diferenciar identidade enquanto uma construção a partir da qual o sujeito pode se inscrever simbolicamente e a imposição de identidade veiculada pelo Outro $^{11}$ com a qual o sujeito terá de se confrontar em seu estádio.

\footnotetext{
${ }^{10}$ É importante ressaltar que os três níveis de identificação acima não cessam de acontecer durante a vida de uma pessoa, ou seja, não se trata de uma progressão.

11 Lacan utiliza a letra maiúscula para designar o grande Outro, marca a diferença com o outro, semelhante, e o Outro representante da cultura, ou seja, a linguagem. Na aula de 15 de novembro de 1961, página XX, encontra-se a seguinte definição: L'Autre le dépotoir des représentants représentatifs de cette supposotion de savoir, et c'est Ceci que nous appelons l'inconscient pour autant que le sujet s'est perdu lui même dans cette supposition de savoir. (O Outro é o depósito dos representantes representativos desta suposição de saber, e é isso que nós chamamos inconsciente que o sujeito está perdido, ele mesmo, nesta suposição de saber"- Tradução de Claudia Rosa Riolfi)
} 


\subsection{O PANORAMA HISTÓRICO}

O panorama deste capítulo tem como ponto de partida dois estudos que abordam a comunidade japonesa no Brasil, a saber, Lesser (2001) e Dezem (2003). O primeiro tem como objeto principal a questão da imigração para compreender o que chama de negociação da identidade nacional, e o segundo toma como objeto os discursos sobre o oriental (japonês e chinês) entre 1878-1908, na tentativa de reconstruir a gênese do discurso que sustentaria a idéia de um "perigo amarelo".

A escolha desses trabalhos como fios condutores para a análise que realizarei neste capítulo justifica-se pela leitura histórica realizada pelos autores dos trabalhos, que se aproximam das finalidades de minha dissertação. O trabalho de Lesser é dedicado ao tema da construção da identidade nacional brasileira enquanto que o de Dezem reconstrói o discurso sobre o amarelo, em especial o japonês, pela mídia.

Lesser (2001) toma como objeto de estudo a imigração para o Brasil, em especial as imigrações sino-japonesas e sírio-libanesas, para compreender como é empreendida a negociação de uma identidade nacional na sociedade brasileira.

Em seu livro A negociação da identidade nacional, Lesser dedica mais da metade da obra para tratar da questão da identidade dos imigrantes e descendentes de japonês. $\mathrm{O}$ autor realiza uma pesquisa documental elencando momentos históricos em que a questão do “japonês” esteve presente nas discussões da constituição de uma identidade nacional.

Para o autor, a escolha pela imigração japonesa como forma de substituir a mãode-obra italiana constituiu uma tentativa de importar, juntamente com os japoneses, as imagens que circulavam sobre o Japão no Brasil desde 1893, com a missão especial de José da Costa Azevedo à Ásia que, ao mesmo tempo em que atacava a China, elogiava o Japão.

A imagem de um Japão que conseguiu se modernizar em um curto espaço de tempo, juntamente com a de um povo honrado e trabalhador, acrescido de um mágico encanto oriental, irá servir de argumento favorável para a utilização da imigração japonesa por parte da elite que visava ao branqueamento pela imigração européia.

A negociação da identidade do imigrante japonês e de seus descendentes contou com a propaganda realizada pelo governo japonês de que o Brasil era um lugar em que se colhia ouro de árvores e de que a vinda para cá era uma possibilidade de expansão da cultura japonesa. No cartaz utilizado para convocar possíveis emigrantes japoneses, 
observa-se um japonês indicando o Brasil, lugar em que se poderá exercer uma atividade e transmitir a cultura japonesa.

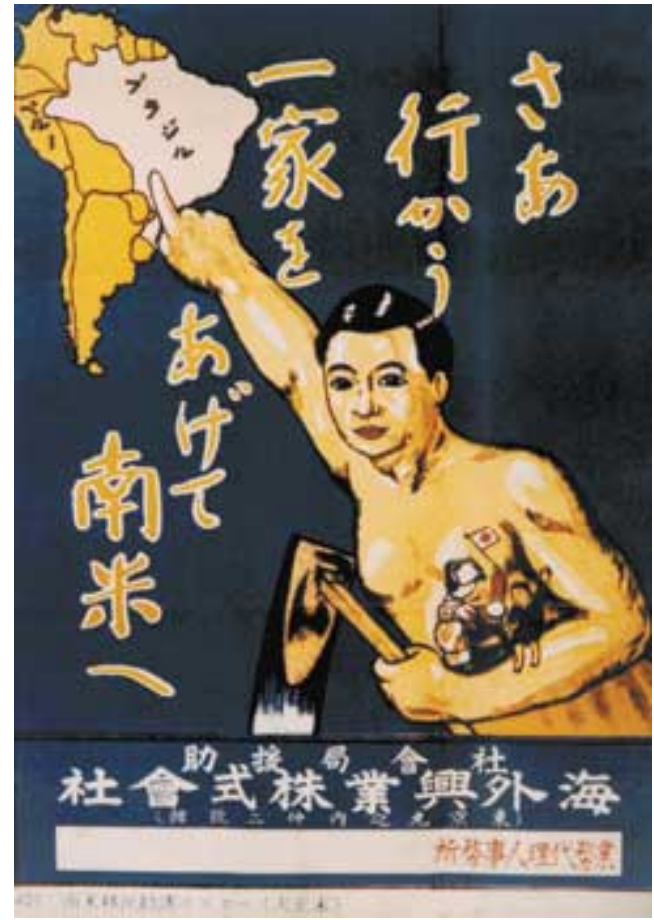

"Vamos! Leve sua família para a América do Sul!" Cartaz de propaganda da KKKK (empresa responsável pela imigração japonesa para o Brasil), década de 20. Cortesia do Centro de Estudos NipoBrasileiros. Brasil São Paulo

(LESSER, 2001: 174)

Figura 1

Ao considerar os diversos discursos com o qual o imigrante japonês e seus descendentes negociam uma identidade caracterizada pela busca de um hífen, o autor salienta a interferência das diversas visões na construção de uma identidade que tenderá para um lado do hífen conforme o interesse. Para o autor:

\begin{abstract}
O Brasil e o Japão poderiam ser inimigos e amigos. Os viajantes poderiam ser sexomaníacos ou clérigos. Não fazia diferença, na análise final. No Brasil, havia um pedaço humano do Japão e, no Japão, os brasileiros encontravam esperanças. Uma falta de espírito nacionalista poderia ser remediada do dia para a noite, graças aos úteros das mulheres japonesas, cujos filhos tornar-se-iam brasileiros melhores. As questões assim levantadas, contudo, não terminaram com o fim da guerra. Entre 1950 e 1990, mais de 50 mil imigrantes japoneses se estabeleceram no Brasil, enquanto 200 mil nikkeis foram trabalhar no Japão. As negociações a respeito da identidade nacional estavam longe de haverem sido concluídas. (LESSER, 2001:289.)
\end{abstract}

O trabalho de Dezem (2003) teve como objetivo principal buscar a gênese do discurso a respeito do amarelo no Brasil, na tentativa de compreender como o imaginário formado a partir desse discurso contribuiria para a sustentação do chamado "perigo amarelo", que serviu como política racista e xenófoba durante o governo Vargas. 
O autor procura elencar elementos da divulgação da figura do "japonês" na imprensa ilustrada da época (1878-1908), especialmente por meio das revistas $O$ Malho e Revista da Semana. O trabalho contrapõe uma imagem divulgada por estas revistas, de um japonês bravo, leal e heróico com a imagem do imigrante real que passa a ser fanático, desleal e traiçoeiro. As primeiras imagens eram associadas com o período da guerra russo-japonesa e as segundas com a chegada dos imigrantes ao Brasil.

\begin{abstract}
Desse modo esperando contribuir com a historiografia contemporânea da imigração Japonesa no Brasil, não podemos considerar apenas a figura do japonês vista sob um prisma negativo quando aqui chegou, o que seria uma afirmação incompleta. Anteriormente a vinda dos japoneses como imigrantes para o Brasil, os discursos transitavam entre uma imagem positiva do Japão e do povo japonês (distante) e negativa com relação ao "imigrante japonês (próximo), a redefinição destas imagens se deu a partir de sua chegada no Brasil. Esse fato fez com que o discurso antinipônico sobre o imigrante japonês, que alcançou o seu auge no período da Segunda Guerra Mundial, tivesse sua gênese nos vários discursos em circulação no final do século XIX. Algumas destas narrativas sustentavam características negativas acerca do imigrante japonês, o associando a idéia de perigo amarelo. Outras ainda que positivas - se lembrarmos aqui aquelas que se referiam com simpatia ao Japão e ao povo japonês durante a Guerra Russo-Japonesa, interpretados como exemplo de civilização, progresso, patriotismo pela imprensa e por boa parcela da opinião pública nacional- se prestaram nas décadas de 1930-1940, para identificá-lo com o imperialismo sem fronteiras no século XIX, os japoneses foram transformados em cruéis espiões representantes de uma raça frígida, fanática e traiçoeira. (op.cit.: 225)
\end{abstract}

A leitura desses dois trabalhos históricos permitiu uma aproximação do contexto pelo qual uma representação da identidade do japonês foi construída na sociedade brasileira. No entanto, pela natureza histórica dos trabalhos, o material apresentado foi tomado como documento em que o discurso cumpria a função de sustentar a linha interpretativa realizada pelos historiadores. Para minha pesquisa, interessa realizar uma análise sobre alguns dos dados extraídos desses trabalhos, na tentativa de aproximar-me das formas lingüísticas utilizadas para representação do japonês.

\title{
1.5 FIGURAS DO JAPONÊS POR MEIO DA MÍDIA
}

\subsubsection{PRIMEIRAS IMAGENS}

Parto da constatação de Dezem (2003) de que o início da veiculação da figura do japonês se inicia na imprensa brasileira após a guerra Russo-Japonesa (1903), momento em que a mídia permite uma circulação de imagens sobre o povo japonês e também a 
publicação da opinião dos leitores. O historiador chama a atenção para a revista $O$ Malho, na edição de número 77 (05/03/1904), cuja capa é composta por uma charge que tematiza a guerra em uma posição mais próxima da neutralidade.

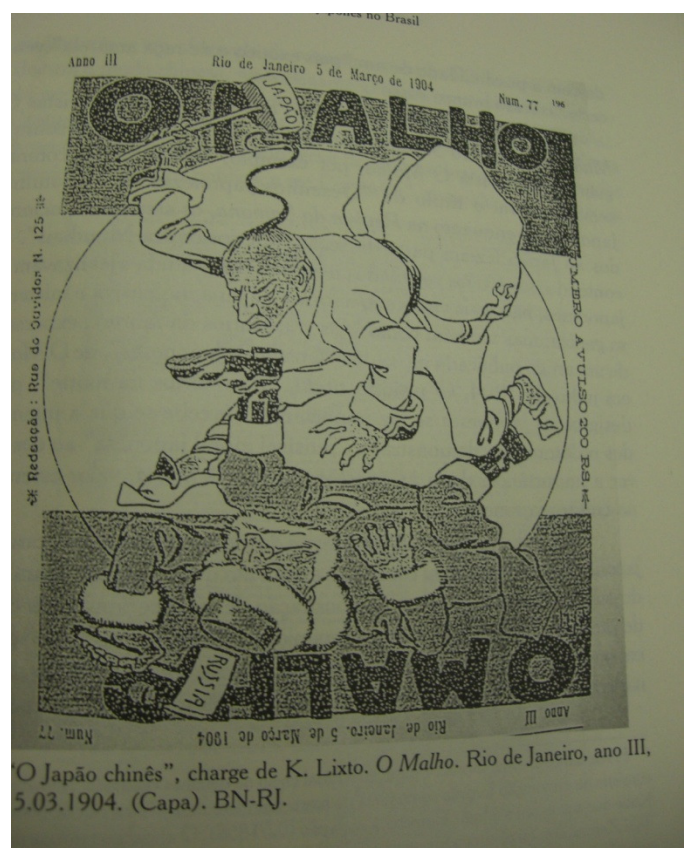

Capa da Revista $O$ Malho 05/03/1904. (Apud DEZEM, 2003: 196)

Figura 2

A capa acima traz a possibilidade de o leitor inverter a posição do suporte em que o texto é materializado, obtendo uma leitura alternada. Na primeira posição (canônica), o elemento que representa o Japão aparece acima, enquanto que na segunda, abaixo, observa-se o elemento representante da Rússia. No entanto, há a possibilidade, ofertada pelo suporte, de realizar a inversão das imagens que se encontram simétricas.

Ainda como lembra Dezem, os traços utilizados para representar o homem japonês estão mais próximos da imagem do chinês (especialmente por causa da trança, elemento ligado à Dinastia Manchu, da China). O autor argumenta que esta imagem pode não somente ser fruto de uma brincadeira do cartunista, mas também do próprio desconhecimento com relação ao japonês.

Esse apontamento de Dezem leva a considerar que a referência à identidade do outro é feita de modo a generalizar: japoneses são todos aqueles que têm olho puxado. Esse modo de se referir ao outro passa sobre um descaso quanto ao que lhe é próprio, não salientando os traços que distinguiriam um japonês de um chinês.

É importante lembrar que, mesmo que estas sejam as primeiras imagens circuladas na imprensa brasileira, elas estão baseadas nos livros de viagens das 
comissões que participaram de expedições ao Japão, de onde traziam as imagens. Segundo Lesser (2001: 269):

\begin{abstract}
O que é notável a respeito desses relatos de viagens é que os temas pouco mudaram ao longo de cinco décadas. Os primeiros capítulos, de natureza histórica, retratam um selvagem e precário Japão pré-moderno, repentinamente transformado num estado moderno e poderoso pela restauração Meiji. Estatísticas sobre produção e fotografias de indústria pesada e de edifícios em estilo ocidental sugerem que o inevitável subproduto da força econômica era a modernidade cultural. O Japão desejável era um Japão ocidentalizado, repleto de bondes elétricos e de construções em altura, feitas de material durável.
\end{abstract}

As reportagens que se seguem nas edições da revista $O$ Malho, após a apresentação da guerra, parecem funcionar como divulgação dos livros de viagem escritos até o momento, mostrando imagens em que o japonês é tratado como um elemento exótico, guardador de qualidades preciososas. Segundo Dezem (2003), no ano de 1904 as duas principais revistas ilustradas do Rio de Janeiro (O Malho e a Revista da Semana) fazem circular matérias que trazem curiosidades sobre o povo japonês.

Um exemplo pode ser encontrado na publicação do artigo Os voluntários da Morte, na revista $O$ Malho $\mathrm{n}^{\circ}$ 97, em 23 de julho de 1904. O artigo tem como tema principal a questão da honra dentro dos costumes japoneses. Mostra que, segundo tais costumes, quando alguém faz algo que é considerado vergonhoso, a pessoa envolvida no caso faz justiça com as próprias mãos, que consiste em se suicidar, abrindo o ventre.

Transcrevo o artigo:

\title{
COSTUMES JAPONEZES - OS VOLUNTARIOS DA MORTE
}

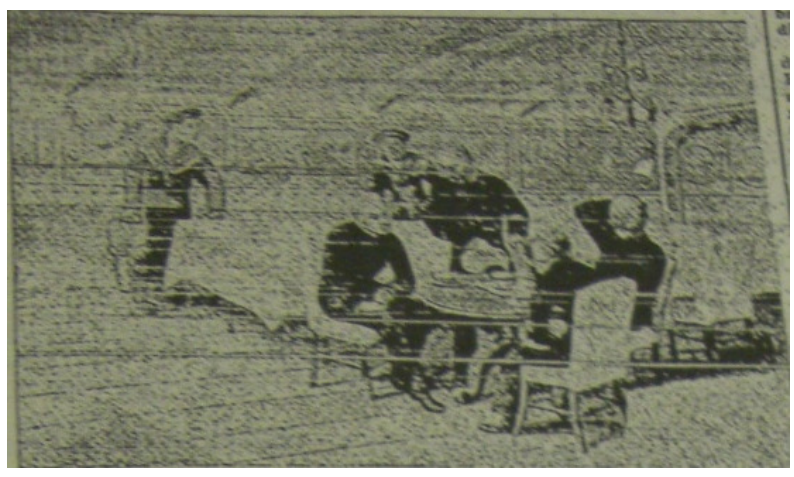

Figura que ilustra o artigo.

(Retirado de DEZEM, 2003: 198)

Figura 3

1 Ha no Japão um costume muito antigo: Quando um japonez é insultado

2 Ou considerado deshonrado, ou quando pratica uma acção má, faz justiça

3 por suas próprias mãos, que consiste, quasi sempre, em se suicidar, abrin- 
4 Do o ventre, etc., etc. Por muito bárbaro que isso nos pareça, não podemos

5 negar que essa sensibilidade moral encerra uma profunda lição de honra,

6 De amor próprio, de intensa dignidade.

7 Hoje, com o decorrer do tempo e o contacto da civilisação occidental

8 esses costumes estão algo adoçados, mas nem por isso os japonezes conside-

9 Ram menos o direito que têm de se punirem por motivos de honra que elles

10 -- bem ou mal, julgam offendida.

11 Um exemplo frisante foi o que nos deu uma das tentativas fracassadas

12 Do engarrafamento da esquadra russa em Porto Arthur. Os officiaes dos

13 brulottes que não conseguiram realisar inteiramente as ordens do almirante

14 Togo, apezar da bravura de que deram provas irrecusáveis, reuniram-se e

15 resolveram castigar-se dessa feia acção, raspando totalmente a cabeça. A

16 presente gravura representa alguns desses officiaes a bordo do seu navio,

17 e assignalados voluntariamente por esse castigo, que, si não foi a morte,

18 materialmente falando, foi um auto-reconhecimento de deshonra, equiva-

19 Lente a uma morte moral.

20 Eis por que esses officiaes, que tiveram a hombridade de se punir tão

21 rudemente, são chamados os voluntários da morte, como aquelles que suppri-

22 Mem realmente a própria existência.

23 Confessemos que, si tudo isto se nos afigura extraordinário, não deixa de

24 Ser uma lição para nós outros, habituados a ver falhar a justiça publica,

25 e até divina sobre a cabeça de réos confessos ${ }^{12} \ldots$

A apresentação de um costume muito antigo (linha 1) dos japoneses é feita tendo em mente os efeitos de sentido que tal costume tem em relação à cultura considerada local, expressa pela primeira pessoa do plural utilizada no texto - nós (linha 4). A exploração do traço exótico pode ser indiciada pelo próprio título Os voluntários da Morte que remete à idéia de suicídio.

A interpretação como exótico pode ser reforçada ao considerar o primeiro parágrafo (linhas 1-6), composto por dois períodos: o primeiro realiza a apresentação do costume sem nenhuma modalização, o que permite ligar o suicídio à permanência da honra e não a um ato de covardia, enquanto o segundo período (linha 4) é iniciado com a antecipação do julgamento de tal atitude Por muito bárbaro que isso nos pareça.

Torna-se significativa a utilização do advérbio temporal no início do segundo parágrafo Hoje (linha 7) que irá se opor à localização temporal do costume apresentado na linha 1 muito antigo. Em um primeiro momento, existia um costume muito antigo que é contraposto com o Hoje, com o decorrer do tempo e o contacto da civilização occidental (linha 7), em que o costume se encontra adoçado. Na continuação deste

\footnotetext{
${ }^{12}$ Foi mantida a ortografia do original.
} 
período, tem-se a inserção de uma conjunção adversativa mas (linha 8) inserindo a permanência deste costume, mesmo que seja em sua forma adoçada.

Ao considerar somente o segundo parágrafo, observa-se o contraste realizado entre o enfraquecimento do costume e a sua permanência após o contato com o ocidente. É possível considerar uma oposição entre um costume bárbaro, símbolo de um Japão selvagem, e a manutenção do traço que encerra uma profunda lição de honra (linha 5) sem a força brutal exposta no parágrafo anterior.

Ganha força esta linha argumentativa se considerarmos que a exposição de um exemplo frisante (linha 11), no qual o ato que simboliza o reconhecimento da própria falha não é a própria morte, mas a raspagem dos cabelos. Se, por um lado, o ato simbólico foi outro, a nomeação é a mesma (linha 21).

Ao utilizar o mesmo nome para marcar uma forma adoçada e a própria morte, é estabelecida uma igualdade que será responsável pela criação de uma ambigüidade que "adoça" o peso do valor semântico da expressão voluntários da morte, na medida em que equaciona o mesmo terror para o ato de raspar as cabeças. Assim, ao mesmo tempo, eleva a atitude de raspar as cabeças a um sinônimo de suicídio.

A construção dentro da estrutura acima identificada, que ao inserir o elemento da cultura japonesa contrapõe com os elementos da cultura ocidental, causa efeitos de ambigüidade na medida em que os valores da cultura japonesa podem ser considerados como positivos, mesmo que a princípio eles sejam configurados como bárbaros frente à cultura tida como "nossa".

Nesse texto, o posicionamento favorável com relação à imagem de japonês guarda também uma parcela de horror, o que sustenta mais tarde a troca da imagem desse japonês honroso pela de um japonês fanático.

Juntamente com a circulação dessas representações, a revista $O$ Malho realizou uma enquete sobre quem iria vencer a guerra, cujo resultado, divulgado em nove de abril de mil novecentos e quatro, consistia em 4.169 votos para o Japão e 1.132 votos para a Rússia.

A receptividade das representações divulgadas pela revista pode ser notada não somente pelo número de votos, mas também pelas cartas publicadas como as dos leitores J. Thomaz e Raul Ribas: 
1 O fraco em lucta desigual, é um povo recentemente admitido ao convívio das

2 nações civilisadas, é uma licção dada ao extravasamento de ambição das grandes

3 potencias, insaciáveis em suas conquistas, e neste particular o exemplo deve ser

4 ponderado pelo Brasil, ameaçado, como está pelo jingoistas da América do Norte e

5 allemães, para reflectir seriamente e tirar dahi as derivativas que bem lhe aprouver

(O Malho, Ano III n 79, Rio de Janeiro, 19 de março de 1904, p. 22. Apud DEZEM: 2003:186).

7 É uma nação digna de sympathia dos idéaes modernos, não só por ser mais fraca e

8 enfrentar sobranceiramente o colosso e autocrata império moscowita numa lucta

9 de vida ou morte, como ainda mais pelo espírito de nacionalismo de seus filhos,

10 que conscientes das ambições da Russia, souberam colocar a sua pátria na altura

11 da eventualidade actual.

(O Malho, Ano III n 80, Rio de Janeiro, 26 de março de 1904. Apud DEZEM, 2003: 186).

Nos dois excertos, é possível depreender imagens que compõem um repertório de um Japão ligado a uma imagem de fragilidade que, no entanto, é digno de um espírito capaz de entrar em uma luta de vida ou morte (linhas 8 e 9). Essas imagens são empregadas tendo como contraponto a idéia de um povo brasileiro que disputa sua autonomia com os americanos e alemães.

Tanto as imagens produzidas pela matéria quanto pelas cartas dos leitores, ao mesmo tempo em que avaliam como positivas as qualidades atribuídas ao povo japonês, também marcam estas qualidades como exóticas e desconhecidas, podendo, inclusive, serem consideradas como algo brutal, fruto de um fanatismo.

A partir da análise realizada por Dezem (2003) e Lesser (2001) é possível observar que a representação do japonês é feita por meio de um jogo entre as mediações pela imagem e pelo símbolo. Busca-se ressaltar alguns significantes tais como honra, lealdade, bravura etc, no entanto, a depreensão de tais traços está intimamente veiculada com a imagem do objeto, um país frágil com costumes bárbaros.

Assim, os sentidos das qualidades são moldados em relação tanto à imagem que é produzida sobre o Japão e seu povo quanto pelos valores considerados dignos de serem destacados. Ao se deparar com uma significação que pode ser considerada 
negativa para cultura local, como o suicídio para expressar a honra, opta-se por marcar euforicamente o significante e atribuir o significado a uma imagem do povo japonês.

Ao considerarmos uma mediação pelo significante, podemos distinguir o que é caracterizado positivamente (honra) do que é caracterizado negativamente (atitude bárbara). Essa estratégia pode marcar duas atitudes, descrita por Landowski (1997), ao lidar com a alteridade: assimilar e excluir. $\mathrm{O}$ autor considera que essas duas atitudes podem parecer distintas aos partidários da assimilação, mas é possível observar entre elas uma espécie de afinidade tática:

\begin{abstract}
Para nos restringirmos ao essencial no que diz respeito a essas duas primeiras configurações, face a uma identidade de referência concebida como perfeitamente homogênea e colocada como que devendo ficar imutável, a alteridade só pode ser pensada como uma diferença vinda de alhures, e que assume, por natureza, a forma de uma ameaça. Como se vê, assimilação e exclusão não passam, em definitivo, das duas faces de uma única e mesma resposta à demanda de reconhecimento do dessemelhante: "Tal como se apresenta, você não tem lugar entre nós". (Op. cit.: 10)
\end{abstract}

Resgatar as formas utilizadas nos primeiros enunciados que veicularam as representações acerca da identidade étnica do japonês, mesmo que ainda não se trate da comunidade nipo-brasileira, justifica-se por permitir compreender com quais imagens os imigrantes e, em seguida, seus descendentes, tiveram de negociar para $\mathrm{o}$ estabelecimento de uma identidade.

Passo, na seqüência, à análise de uma revista periódica publicada cento e três anos após a circulação dos exemplares que continham os enunciados analisados nessa seção para verificar se houve mudanças significativas no modo de construção das declarações sobre a identidade étnica associada ao imigrante japonês e seus descendentes.

\title{
1.5.2 DA CONTINUIDADE DO IMAGINÁRIO
}

$\mathrm{Na}$ tentativa de perseguir a construção do imaginário em torno da identidade do "japonês" no Brasil, passo a contrastar enunciados veiculados na revista Veja de 12 de dezembro de 2007. Trata-se de um número que tem como reportagem de capa a comemoração dos cem anos da imigração japonesa.

A edição, que possui duzentas e duas páginas, dedica a capa, a seção carta ao leitor e mais sete matérias que ocupam quarenta e cinco páginas ao tema da imigração 
japonesa. Além dessas partes, ainda são encontradas uma imagem de Tóquio ilustrando o sumário e uma propaganda do banco Real, dedicada a divulgar produtos para a comunidade nipo-brasileira.

As sete matérias distribuídas entre as páginas 78 e 140 são: Os 100 anos da imigração japonesa; A história das gerações; Os que vieram, os que ficaram e os que voltaram; Imagens do Japão; As mulheres que dizem não; Velhice dourada; $e$ Dekasseguis:o refluxo migratório.

Esta edição surge cento e três anos depois da veiculação das primeiras figuras que antes precisavam ser desenhadas para ilustrar os japoneses. A mídia agora pode capturar em foto tanto os japoneses quanto seus descendentes. Ao longo de todas as reportagens, a escolha para as ilustrações é feita por meio de fotografias, fato que aumenta a sensação de veracidade, como pode ser observado desde a capa.

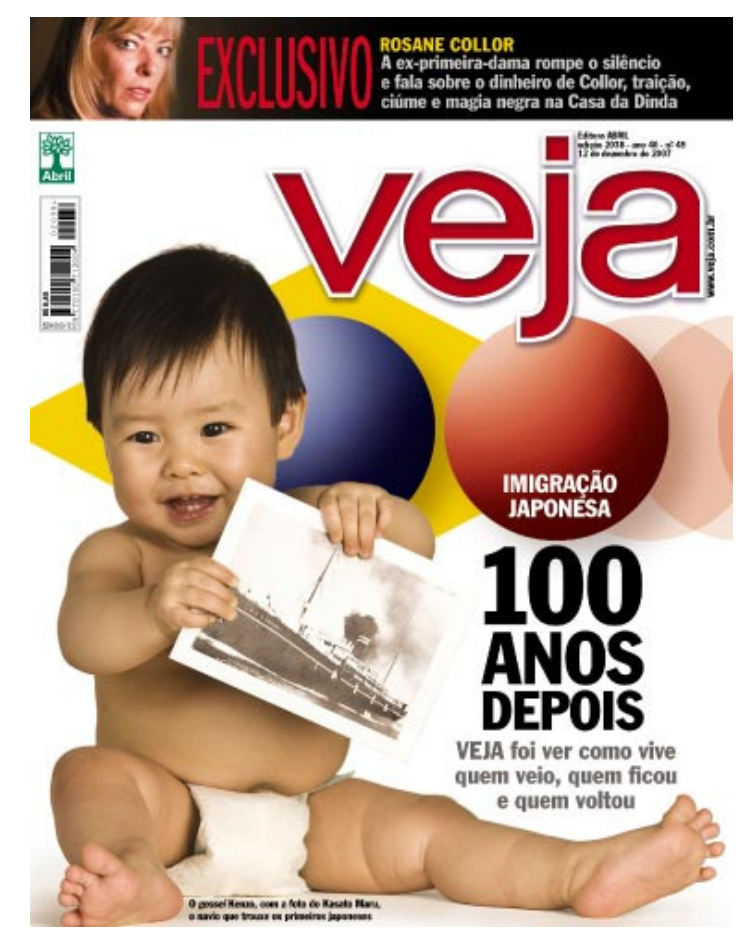

Figura 4

A capa da revista é produzida a partir da foto de um bebê segurando uma outra foto. Abaixo traz a seguinte legenda: $O$ gossei Kenzo, com a foto do Kasato Maru, o navio que trouxe os primeiros japoneses. A capa acaba por sobrepor dois momentos históricos, qual seja: um primeiro representado pela foto do navio, marcando um ponto de partida do processo da imigração, e fotografia de Kenzo como um dos resultados desse processo. 
Ao somar a fotografia com o texto ao lado, que ocupa posição central na capa, Imigração Japonesa - 100 anos depois VEJA foi ver como vive quem veio, quem ficou e quem voltou, pode-se depreender uma construção das representações que, diferentemente dos exemplos analisados anteriormente, possuem um referente concreto.

Nos textos veiculados pelas revistas $O$ Malho e Revista da Semana, o referente encontrava-se no povo japonês, na sua cultura e os referentes concretos, como os officiaes utilizados na matéria Os voluntários da morte, eram invocados como exemplos que sintetizavam a identidade do japonês. Na construção da capa da revista Veja a relação é invertida, é a partir dos referentes (quem veio, quem ficou e quem voltou) que a identidade será depreendida.

A matéria A história das gerações ocupa oito páginas, sendo que duas são dedicadas para cada uma das quatro primeiras gerações. Cada seção começa com a designação da geração e um subtexto com um resumo sobre a geração. Ainda possui uma foto na parte superior que ocupa as duas páginas e uma legenda da foto no lado inferior indicando o nome das pessoas que aparecem na imagem.

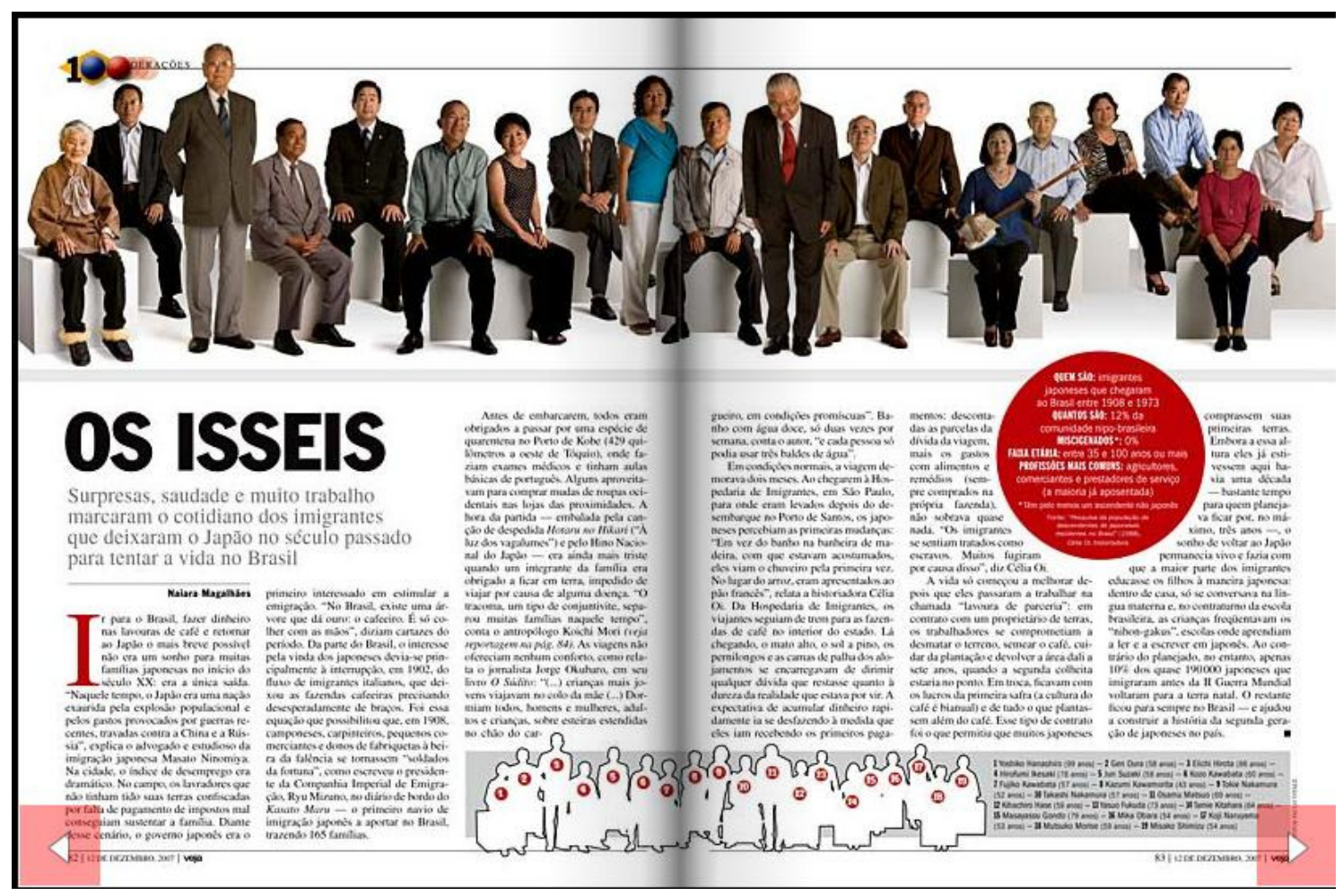

Figura 5

Pode-se observar a importância dada para veicular fotografias que servem para dar valor de realidade ao inserir legendas que individualizam cada uma das pessoas que 
aparece na imagem, ou seja, não é apenas uma ilustração de cada uma das gerações. No entanto, ao longo da reportagem a respeito do Japão, vão sendo inseridas fotografias com detalhes que buscam o exótico, por exemplo, a imagem que aparece no sumário da revista:

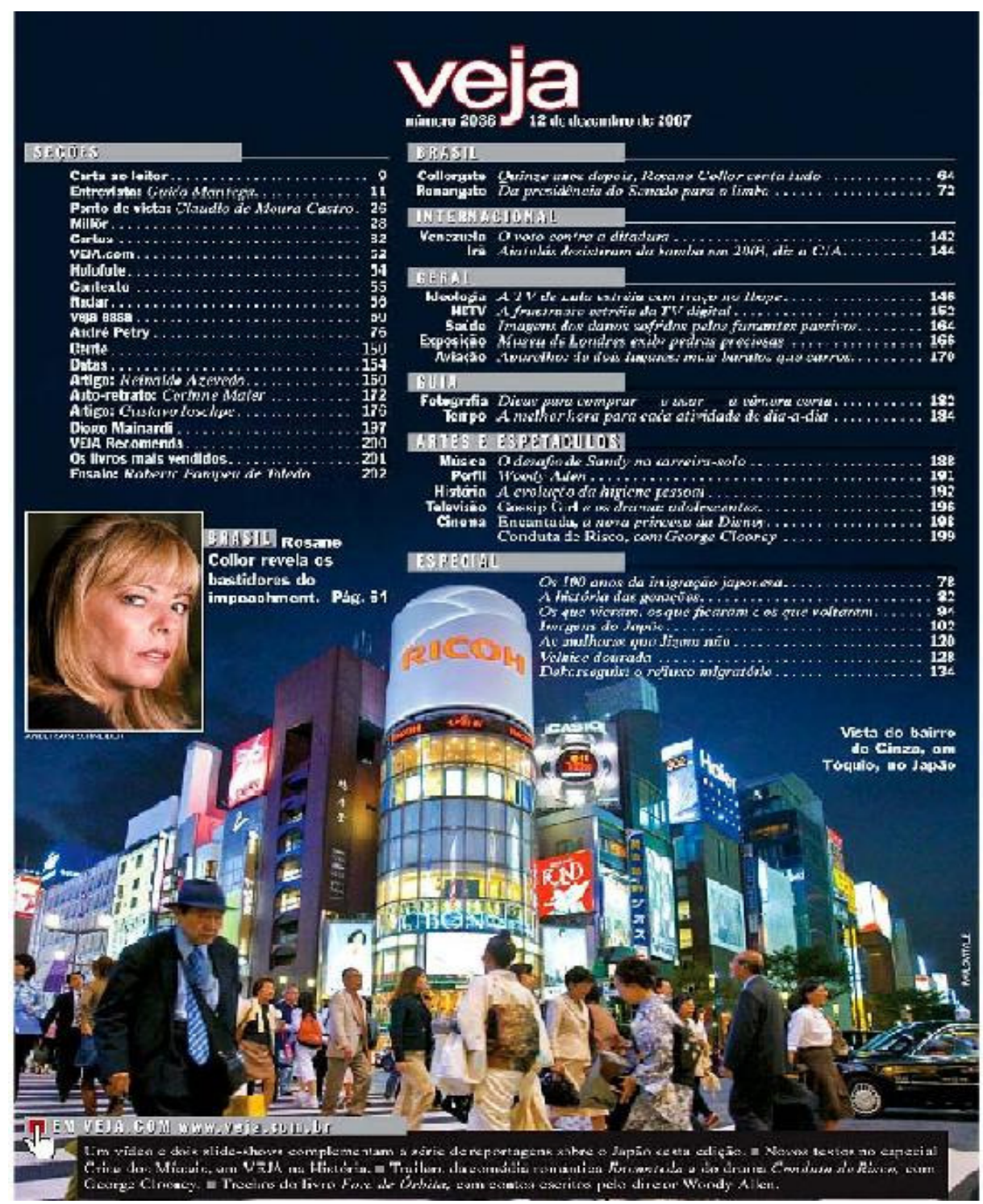

Figura 6

A foto acima aparece com a seguinte legenda: Vista do bairro de Ginza, em Tóquio, no Japão. Na foto, pode-se observar a existência de grandes prédios comerciais que possuem fachadas com displays de neon, uma das marcas de cidades modernas. Ao olhar para as pessoas que atravessam o cruzamento, duas senhoras aparecem em primeiro plano utilizando kimonos. 
Torna-se interessante a escolha desta foto para ilustrar o sumário, uma vez que é possível observar um trabalho na construção das fotografias utilizadas como formas de capturar a realidade. No entanto, a indumentária utilizada pelas senhoras dessa fotografia restringe-se a contextos específicos, não fazendo mais parte do cotidiano.

Nessa direção, pode-se considerar que, mesmo partindo de uma posição diferente daquela dos textos anteriormente analisados, as representações veiculadas pela revista Veja mantêm uma contigüidade na construção do imaginário associado à identidade do japonês. Para depreender alguns desses traços que persistem, passarei à análise da Carta ao leitor, que transcrevo abaixo:

\section{Parceria de um século}

\section{Paulo Vitale}

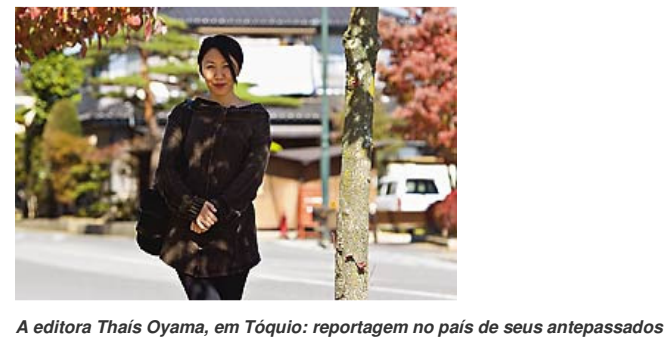

Figura 7

1 Em 18 de junho do ano que vem, será comemorado o centenário da emigração

2 japonesa para o Brasil. Nesta edição, VEJA antecipa-se à data, com a publicação

3 de uma reportagem de 45 páginas que certamente interessará não apenas às pessoas

4 com raízes no Japão. Os brasileiros com ascendência japonesa formam um exército

5 de 1,2 milhão de pessoas. Em sua maioria esmagadora, eles integram uma classe

6 média laboriosa e bem-educada, que brilha nas áreas de engenharia, arquitetura,

7 medicina e computação, principalmente, para alegria de seus pais e avós, oriundos

8 do trabalho braçal nas lavouras. A reportagem de VEJA mostra como as diversas

9 gerações foram se integrando com sucesso à sociedade brasileira. Também traz um

10 capítulo emocionante sobre vidas paralelas. Uma sociedade brasileira. Também

11 traz um capítulo emocionante sobre vidas paralelas. Uma das histórias é a de duas

12 irmãs separadas pela imigração. Uma veio para o Brasil aos 10 anos, enquanto a

13 outra teve de permanecer do outro lado do mundo. Os relatos sobre o Japão atual,

14 com suas peculiaridades sociais e demográficas, são saborosos e informativos.

15 Para fazer essa reportagem, VEJA destacou a editora Thaís Oyama. Acompanhada

16 pelo fotógrafo Paulo Vitale, ela permaneceu durante vinte dias no Japão. Thaís

17 entrevistou meia centena de pessoas. De especialistas em demografia e autoridades

18 a cidadãos comuns e dekasseguis - como são chamados os nipo-brasileiros que

19 voltaram ao Japão em busca de emprego, outro fenômeno abordado pela

20 reportagem. Para Thaís, a viagem teve um significado duplamente especial: ela é

21 sansei. Ou seja, neta de imigrantes. Nascido na província de Gifu, seu avô materno,

22 Güichi Maeda, de 95 anos, chegou ao Brasil em 1932. Ele trabalhou durante dois 
23 anos numa fazenda de café, no interior de São Paulo, antes de fixar-se na cidade de

24 Marília, onde se tornou confeiteiro e conheceu a sua futura mulher, também

25 japonesa. "Meu avô foi esperto: casou-se com a filha do dono da confeitaria",

26 diverte-se Thaís. O senhor Maeda tem todos os motivos para sentir orgulho de sua

27 neta.

No primeiro parágrafo de apresentação da revista (em especial linhas 6-8), é possível depreender uma imagem do "japonês" que se alinha com as imagens veiculadas pelos enunciados postos em circulação nas revistas de 1904. Entretanto, esta reportagem parte de um outro ponto, pois, se nas primeiras as imagens eram feitas com base em fatos relatados à distância, as imagens produzidas pela revista Veja pretendem ser construídas a partir do exército de brasileiros com ascendência japonesa (linhas 4-5).

Os traços que podem marcar uma continuidade com o processo de representação descrito anteriormente na análise dos textos 1904 podem ser indiciados nos quatro últimos períodos do texto:

Para Thaís, a viagem teve um significado duplamente especial: ela é sansei. Ou seja, neta de imigrantes. Nascido na província de Gifu, seu avô materno, Güichi Maeda, de 95 anos, chegou ao Brasil em 1932. Ele trabalhou durante dois anos numa fazenda de café, no interior de São Paulo, antes de fixar-se na cidade de Marília, onde se tornou confeiteiro e conheceu a sua futura mulher, também japonesa. "Meu avô foi esperto: casou-se com a filha do dono da confeitaria", diverte-se Thaís. O senhor Maeda tem todos os motivos para sentir orgulho de sua neta.

O excerto transcrito acima é fechado com a descrição da história familiar de Thaís, que foi ao Japão para elaborar as matérias referentes ao arquipélago. A filiação é apresentada pela explicação da palavra sansei, pessoa de terceira geração, e passa-se a fornecer informações sobre o percurso do avô da editora, período que é finalizado pela incorporação de um enunciado marcado como sendo de Thaís: "Meu avô foi esperto, casou-se com a filha do dono da confeitaria”, diverte-se Thaís'. A utilização do predicado esperto contribui para a representação de uma identidade ligada simultaneamente ao sucesso e ao perigo.

Parece-me que a ambigüidade com relação à identidade japonesa, aquela digna de respeito pelas conquistas que obtém, ao mesmo tempo em que está ligada a uma imagem de terror, não é desfeita, mas deslocada. 
Nessa direção, ao considerar o período em que os predicados atribuídos para caracterizar a comunidade nipo-brasileira também podem ser elencados como continuidade da representação construída em torno dessa identidade étnica:

Os brasileiros com ascendência japonesa formam um exército de 1,2 milhão de pessoas. Em sua maioria esmagadora, eles integram uma classe média laboriosa e bem educada, que brilha nas áreas de engenharia, medicina e computação (...)

Enquanto no texto $O s$ voluntários da morte é preciso explicitar o sentido positivo depreendido das atitudes do japonês, sempre dialogando com um nós, brasileiros, os predicados atribuídos pela revista à identidade do japonês não necessitam de uma contextualização para serem considerados eufóricos (laboriosa; bem-educada e que brilha).

Se, por um lado, os adjetivos não são mais contextualizados para ganhar o traço de positivo, por outro, há o emprego de palavras (exército, maioria esmagadora) cujo conteúdo pode fazer ecoar a ambivalência analisada no texto Os voluntários da morte, no qual a lição de honra está ligada a um ato brutal.

Essa linha de interpretação ganha força se associada com alguns enunciados que circulam acerca do japonês, tais como enquanto você está brincando, tem um japonês estudando, empregado quando o assunto é a entrada na universidade, em especial, em relação às áreas citadas pela revista (engenharia, arquitetura, medicina e computação linha 6).

De forma similar às construções analisadas anteriormente, a mediação em tal enunciado parece atingir dois níveis simultaneamente: um primeiro marcado pela utilização dos significantes laboriosa, bem-educada, que brilha, remetendo a características que designariam traços que compõem a formação da identidade japonesa; e um segundo no qual os significantes não deixam de ser remetidos ao objeto que os designa (exército, maioria esmagadora), o qual contém traços considerados disfóricos.

Além de ser possível observar uma continuidade nas formas de construção de um imaginário associado aos imigrantes japoneses e seus descendentes, pode-se observar que a exaltação das qualidades atribuídas a esse grupo étnico encontra sua motivação no interesse econômico. No primeiro momento histórico, busca-se justificar os elementos disfóricos na tentativa de tornar esse grupo uma das fontes de mão de obra 
e do projeto de branqueamento da sociedade brasileira. Já no momento atual, as qualidades destacadas estão diretamente ligadas ao sucesso no mercado de trabalho.

Após a apresentação desse panorama das representações circuladas pela mídia em dois momentos históricos diferentes, passo à análise dos enunciados produzidos pelos membros autorizados a falar em nome da comunidade nipo-brasileira.

\subsection{FIGURAS DA PRÓPRIA COMUNIDADE NIKKEI: OS REPRESENTANTES DAS ENTIDADES NIPO-BRASILEIRAS}

Neste item, considerarei as imagens formadas por membros da própria comunidade nipo-brasileira. Os textos que tomarei para análise encontram-se publicados no livro O Futuro da Comunidade Nikkey, organizado por Masato Ninomiya como resultado do simpósio de comemoração dos oitenta e cinco anos da imigração japonesa no Brasil, publicado três anos depois, em 1996.

Trata-se da apresentação de um documento produzido a partir da fala de representantes de entidades da comunidade nipo-brasileira que participaram do simpósio acima mencionado.

Feita a contextualização do processo de produção dos textos que serão analisados, reproduzo abaixo o primeiro parágrafo da apresentação:

1 Não se pode ver com otimismo o futuro da comunidade nikkey no Brasil e, talvez,

2 não seja o caso de ficarmos apenas nas festas e comemorações, tanto pelo

3 centenário da amizade Brasil-Japão, ou do $90^{a}$ aniversário da imigração que

4 ocorrerá dentro de dois anos. Com algumas honrosas exceções, as atividades das

5 entidades nikkey têm estado em baixa, e apesar dos esforços desenvolvidos em

6 conquistar novos sócios, é inegável que muitos estão se afastando dos clubes e

7 associações a que pertenciam...

(NINOMIYA, 1996:10)

O enunciado acima reproduz o tom pessimista dado à continuação da cultura na comunidade nipo-brasileira. O parágrafo se inicia com um período composto por duas orações coordenadas unidas pela conjunção “ $e$ ” (linha 1): a primeira oração se inicia na negativa, questionando o futuro da comunidade nikkey, e a segunda indica o relacionamento do futuro da comunidade como restrito aos momentos de festas (linhas 2 e 3). Se o primeiro período (linhas 1-4) aponta para um futuro que corresponde aos 
eventos realizados pela comunidade, o segundo (linhas 4-7) indica o enfraquecimento das instituições que organizam tais eventos.

Dentro desta atmosfera de preocupação com a preservação da cultura japonesa no interior da comunidade nikkey, tentarei delinear mecanismos que possam me auxiliar na descrição das representações dadas à comunidade.

Entre os textos que compõem o livro, escolhi para análise Comunidade, a cultura e as entidades nikkey do Brasil, escrito pelo Diretor da Sociedade Brasileira da Cultura Japonesa, porque apresenta a narração do perfil dos candidatos que concorrem a bolsas de estudos no Japão oferecidas por uma associação. Trata-se da visão de um dos avaliadores, a qual se torna interessante por servir como indício de uma voz de autoridade que determina o grau de nipocidade, termo utilizado para descrever a relação entre nipo-descendentes e a cultura japonesa.

1 Como membro de uma comissão de trabalho da Sociedade Brasileira de Cultura

2 (doravante denominada Bunkyo), a de Bolsa de Estudos, tenho tido a oportunidade

3 de me defrontar com alguns candidatos a bolsa que muitas vezes apresentam

4 apenas um tênue vestígio de consangüinidade. Já não possuem o tipo físico japonês

5 e sequer têm o patronímico "tipicamente" japonês. Por assim dizer, são pessoas

6 que se fôssemos medir seu grau de nipocidade (medida que particularmente reputo

7 odiosa, carregada de conotação preconceituosa), estariam mais próximas de zero

8 do que de um.

(HAYASHI, 1996: 62)

O trecho inicia-se apresentando um argumento de autoridade, explorando a posição do enunciador para, depois, iniciar a descrição dos candidatos. A introdução dos bolsistas é feita pelo verbo defrontar (linha 3), que contém um traço de aversão. Logo após é apresentado o complemento do verbo com alguns candidatos a bolsa que muitas vezes apresentam tênue vestígio de consangüinidade (linhas 3 e 4).

Nesta construção, é interessante observar a ambigüidade gerada pela utilização dos quantificadores alguns e muitas. Mesmo considerando que o alguns quantifica candidatos e muitas quantifica vezes, há uma quebra da lógica do escopo, já que o complemento vestígio de consangüinidade não pode ser apresentado mais de uma vez por candidato.

A seqüência do texto dá prosseguimento à construção do tênue vestígio de consangüinidade (linha 4) elencando elementos biológicos que culminam na criação de um grau de niponicidade (linha 6). Porém, esses critérios não são os utilizados para a 
escolha do perfil do candidato, uma vez que são carregadas de conotações preconceituosas (linha 7).

Na sequiência, passo à análise dos períodos seguintes, que fazem parte do mesmo parágrafo:

1 A maioria deles tem me surpreendido muito, porquanto, embora à primeira vista

2 não pareçam nikkey, eles o são muito mais do que muitos que aparentam ser.

3 Dominam bem o idioma japonês, têm atitudes e gestos que consideramos típicos

4 dos nihonjin, e alguns deles chegam a apresentar mais conhecimentos de cultura

5 japonesa e do próprio Japão que nós mesmos.

(HAYASHI, 1996:62)

O que se segue ao trecho analisado anteriormente vem demonstrar uma postura que procura ir além das conotações preconceituosas e passa a apresentar categorias que seriam mais adequadas para depreender o grau de nipocidade, como o domínio do idioma e posturas consideradas típicas. É interessante observar que as atitudes e gestos (linha 3) ganham valores somente pelos complementos tipicamente dos nihonjin (linha 4) - japoneses -não havendo nenhuma explicitação do que venha a ocupar estas categorias.

Se no primeiro trecho esses descendentes são a causa da perda dos traços que garantiriam a nipocidade pelas características biológicas, no segundo parágrafo esta descendência é ignorada em favor dos conhecimentos da cultura japonesa.

Ao confrontarmos os dois trechos analisados, alguns movimentos merecem ser salientados. No primeiro trecho, tem-se a construção de argumentos que buscam demonstrar o desaparecimento dos traços (biológicos) da comunidade nikkey, enquanto que no segundo existe uma valorização dos traços tipicamente dos nihonjin, mas em ambos os lados não há nenhuma consideração acerca dos descendentes de imigrantes propriamente ditos.

Pode-se também estabelecer uma continuidade do processo de construção da identidade nipo-brasileira por uma predominância da imagem sobre o significante. No caso dos enunciados produzidos pelas autoridades de entidades representantes da cultura japonesa no Brasil, o jogo é estabelecido entre um ideal tipicamente nihondin e as características físicas apresentadas pelas gerações como forma de suplantar o desaparecimento dos traços biológicos. 
Ao escolher privilegiar uma imagem que comporia os traços do predicado tipicamente nihondin, ao mesmo tempo em que se tenta afastar de uma postura qualificada de preconceituosa, abra-se mão do compromisso de acolher aqueles que possuem poucas características físicas e poucos vínculos culturais.

Observa-se um movimento em duas direções, primeiramente apontando para o desaparecimento dos traços que marcariam a comunidade nipo-brasileira que estaria ameaçada pela perda de sua identidade e sua cultura. E depois a apropriação dos traços que compõem esse imaginário por pessoas que supostamente estariam no grupo étnico.

Se por um lado é possível afirmar que esses enunciados adotam uma postura contrária à exaltação realizada nos enunciados postos em circulação pela mídia que busca salientar as qualidades do grupo; por outro, observa-se que em todos os enunciados busca-se forjar uma representação da identidade associada aos imigrantes japoneses e seus descendentes cujo principal objetivo é reforçar o imaginário utilizado para realizar a declaração sobre a identidade étnica.

\subsection{REPRESENTAÇÕES DA IDENTIDADE NAS DECLARAÇÕES DE NIPO- BRASILEIROS}

Para fechar este capítulo, realizarei a análise de enunciados produzidos por nipobrasileiros. Esses enunciados permitirão depreender as representações produzidas pelos próprios descendentes de imigrantes japoneses para a afirmação de sua identidade étnica. Os enunciados foram recolhidos da comunidade Sou Japa com (mtu) Orgulhu e das entrevistas realizadas com nipo-brasileiros. Da comunidade, selecionei sua descrição, que apresenta as razões para integrar o grupo e vinte enunciados produzidos no período de 12/05/2005 a 25/12/2005, no tópico vcs nunca foram nihongin! Das entrevistas, foram selecionados os enunciados em que os informantes buscaram definir suas próprias identidades étnicas.

Os enunciados recortados dessa comunidade tornam-se um contraponto aos que foram recortados dos textos de representantes de entidades culturais nipo-brasileiras. Por um lado o representante de uma comunidade, no sentido tradicional do termo, aquela que freqüenta uma entidade, reclama que as pessoas não participam mais das atividades dessa comunidade. Por outro, uma comunidade virtual formada pelos descendentes de imigrantes convoca outros membros para compartilharem a designação

de nihondin. É interessante perceber que o sentimento de pertença, embora possa se 
esfumar um pouco, continua latente, servindo de argumento para a criação da comunidade virtual.

A descrição da comunidade Sou Japa com (mtu) Orgulhu busca apresentar as características que definem os predicados dos elementos que compõem a identidade étnica dos nipo-brasileiros. Assim, apresenta as representações que podem incluir uma pessoa dentro do grupo.

Abaixo apresento a descrição da comunidade:

$1 \quad$ Ve tem orgulhu di ser nihondin!??

2 naum liga pra akelas pssoas idiotas ki fikm mexendu com a gnt

3 no meiu da rua falandu "arigatoh" "sayonara"i etc i talz...??

4 acha os(as)japas bonitus(as)??

5 Se você tem orgulho de ser nihondin, mesmo não tendo nascido

6 no Japão, diz pra todo mundo se é nisei ou sansei ou não sei ,

7 vive falando japonês misturado com português ou fala japonês

8 Só pros gaijins não te entenderem., e acha o Japão O País

9 mesmo nunca tendo ido pra lá..

10 e por mais tantos motivos de nós "japas" adoramos o nihon e de

11 sermos japas, se você se encaixa neste perfil

12 join us...

A partir dessa descrição, pode-se depreender a criação de um conjunto no qual os elementos compartilham o predicado ter orgulhu di ser nihondin (linha1). A descrição procura elencar outros predicados que definiriam as características que constituiriam o conjunto. Essas características são determinadas por cinco predicados:

A- Não ligar para os comentários pejorativos feitos por pessoas fora do grupo (linha 2 e 3);

B- Achar os japoneses bonitos (linha 4);

C- Assumir a designação de acordo com a descendência (linha 6);

D- Utilizar a língua japonesa (linha 7); e

E- Gostar do Japão (linha 8).

Os predicados acima, por sua vez, podem ser separados em dois grupos. O primeiro, constituído por A e D, determina relações mantidas pelo grupo com as pessoas que não pertencem a ele, ou seja, os denominados de gaijins (linha 8) e o segundo grupo, formado por B, C e E, marca relações dos elementos do grupo com a etnia japonesa. 
A relação estabelecida com a alteridade, primeiro grupo, busca ressaltar estratégias utilizadas pelos membros da comunidade e os que não pertencem a esse conjunto para construir a diferença entre os conjuntos. Para a sustentação dos predicados A e D, remete-se à utilização da língua como recurso para instaurar a divisão entre os membros da comunidade e seu exterior.

Nas linhas 2 e 3, encontra-se o enunciado a partir do qual o predicado A pode ser depreendido: naum liga pra akelas pssoas idiotas ki fikm mexendu com a gnt no meiu da rua falandu "arigatoh" "sayonara" $i$ etc $i$ talz...?? O enunciado desqualifica a estratégia utilizada pelos elementos que não pertencem ao conjunto da comunidade para identificar seus membros.

Primeiro afirma-se que os membros da comunidade são caracterizados pelo outro (akelas pssoas) por meio de itens lexicais atribuídos à língua e à etnia japonesa. Acerca dessa afirmação é inserida a desqualificação dos agentes que realizam essa caracterização. É sobre a construção akelas pessoas idiotas ki fikm mexendu com a gnt no meiu da rua falandu "arigatoh" "sayonara" $i$ etc $i$ talz... que incide o verbo ligar, ou seja, primeiramente há um encadeamento de afirmações (liga pra akelas pessoas...) e a respeito dessa afirmação incide a negação como forma de não legitimar a atitude por meio da qual o grupo é caracterizado pelo seu exterior.

Ao mesmo tempo em que não considera legítima tal atitude, busca-se construir a noção de posse da língua japonesa, como se pode depreender do enunciado a partir do qual foi obtido o predicado D (linhas 7 e 8). Vive falando japonês misturado com português ou fala japonês só pros gaijins não te entenderem.

A utilização de itens da língua japonesa pelo outro como forma de delimitar o grupo é considerada não legítima. Porém, torna-se uma estratégia legítima quando utilizada pelo grupo, ou seja, a utilização da língua japonesa como forma de estabelecer o limite entre dentro e fora do grupo é tida como legítima somente pelos elementos que compõem a comunidade.

Essa interpretação reforça a análise apresentada anteriormente, na qual argumentei que o advérbio de negação é utilizado sobre o escopo das afirmações construídas inicialmente nas frases. Assim, não se nega a estratégia utilizada para delimitar os grupos, a negação visa ao outro enquanto representante do grupo exterior, os gaijins.

A diferenciação entre o grupo e o outro pode ser sintetizada pelo emprego das palavras nihondin e gaijin. O primeiro termo está ligado às representações dos 
elementos que fazem parte do conjunto da comunidade, enquanto o segundo está ligado aos elementos exteriores.

O estabelecimento dos limites é feito por meio do segundo grupo de proposição elencados acima, ou seja, aquelas que marcam relações estabelecidas com a etnia japonesa. Assim, observa-se que o limite é estabelecido pela afirmação das características dos denominados nihondin, enquanto gaijin é o termo utilizado para denominar todos os não pertencentes ao grupo.

É importante ressaltar que os termos nihondin e gaijin podem expressar julgamentos de valores dentro da comunidade nipo-brasileira. O primeiro muitas vezes é empregado como um adjetivo eufórico, enquanto o segundo como disfórico. $\mathrm{Na}$ descrição acima, é possível depreender que o emprego desses dois itens também produz os efeitos de sentido marcados pela comunidade, ao relacionar um subgrupo dos denominados gaijins com akelas pssoas idiotas.

O estabelecimento do significado de nihondin é feito não somente em contraste com o exterior, mas, em especial, com as próprias características do grupo. Em dois momentos do enunciado, utiliza-se a expressão mesmo (linhas 5 e 9) para inserção de orações intercaladas que cumprem a função de aumentar o escopo do item lexical nihondin, usualmente utilizado para designar a pessoa que nasce no Japão.

Assim, pode-se perceber uma predominância de mediação pela imagem. A utilização de significantes em língua japonesa também está ligada à imagem que esses significantes transmitem. Diante dos significados que um item como nihondin pode expressar, é preciso inserir outros enunciados que possam garantir a integridade da imagem do grupo.

Ao fazer uso desse recurso, o enunciador busca reforçar a relação de sinonímia estabelecida entre japa (presente no nome da comunidade e nas linhas 10 e 11) e nihondin (utilizado nas linhas 1 e 5) para designar os elementos que compõem o conjunto da comunidade virtual. É essa relação que é questionada no tópico de discussão nomeado de vcs nunca foram nihonjin!.

1 Meu,nao viaja!

2 Como vcs podem falar q são nihonjin??

3 Nihonjin=aquele que nasceu no Japao,cujo os pais tambem.

$4 \quad \mathrm{Vcs}=$ nasceram no Brasil,de pais ou avos com decendencia japonesa.

5 Issei=nihonjin=japonês

6 Nissei=filhos de decendentes (traducao de NISSEI=segunda geracao) 
$7 \quad$ Sansei=netos de decendentes (traducao de SANSEI=terceira geracao)

8 No Japão vcs nunca serão considerados japoneses,nao adianta!

9 Todos ves q tem olhos puxados,nao anda com brasileiros ou mesticos, ves todos sao NISEMONO!(vai procurar no dicionario,vai!)

10 Vcs todos sao TCHUTO HAMPA!(vai procurar de novo no dicionario,vai!)

11 Eu nunca precisei de nihongo gakkou,pq eu estudei no Japao.

12 Sou muito mais cobicada do que ves,pq japones adora GAIJIN, a adora MESTICOS e NEGROS tb!

13 Passe bem!

O tópico de discussão é aberto por um enunciado que busca desconstruir a descrição da comunidade. A estratégia utilizada pelo enunciador consiste em fornecer os significados dos itens lexicais nihondin/issei (linhas 3 e 5), nissei (linha 6) e sansei (linha 7) utilizados na descrição da comunidade, questionando a legitimidade do emprego do termo nihondin pelos elementos da comunidade (linha 4). Utiliza-se argumentos de autoridade para opor ideologia a saber enciclopédico.

$\mathrm{Na}$ descrição da comunidade, a identidade é definida de acordo com os predicados que apresentam as características do nihondin, termo utilizado como sinônimo para japa, nissei, sansei e não sei. O termo gaijin é generalizado para todos os outros elementos. No enunciado do tópico de discussão, ao contrário da descrição da comunidade, as nomeações das diferentes etnias são utilizadas para individualizar, colocando em jogo uma distinção de grupos diferentes: os elementos da comunidade (enunciados como vocês), os japoneses (considerado somente para as pessoas que nasceram no Japão), os gaijins, os mestiços e os negros.

$\mathrm{Na}$ tentativa de explicitar um possível sentido preconceituoso expresso pelos itens lexicais gaijin/nihondin utilizado na descrição, o enunciador busca mostrar a incongruência do segundo para nomear os elementos da comunidade (linhas 1 a 8). Assim, o próprio enunciado acaba por (re)produzir o preconceito ao qual tenta se opor, uma vez que irá considerar como dignas de receber a nomeação legítima de "japoneses" somente as pessoas nascidas no Japão, reproduzindo inclusive as estratégias elencadas na descrição (a utilização da língua japonesa - linhas 9 e 10), utilizando os itens lexicais nisemono (linha 2) e tchuto hampa (linha 10) para designar os elementos da comunidade. Trata-se de uma tentativa de controle da significação, ou seja, busca-se impedir a resignificação dos termos exigindo que se sigam os sentidos autorizados pelo dicionário. 
Enquanto a descrição procura criar uma dicotomia entre nihondin, (termo eufórico) abrangendo todos os descendentes, e gaijin (termo disfórico), utilizado para referir-se aos elementos que não fazem parte do grupo, o enunciado do tópico busca implodir a unidade conferida pelo significante gainjin. O enunciado produzido para a abertura do tópico de discussão polemiza a definição da identidade étnica apresentada pela descrição da comunidade, no entanto, é possível depreender que a disputa pela definição também fica reduzida a uma disputa da imagem do que pode ser nomeado de nihondin e gaijin.

A mediação pela imagem torna-se mais saliente ao atentar para as categorias criadas para delinear as identidades étnicas. Os significantes utilizados funcionam na medida em que os objetos são considerados como parte da enunciação, uma vez que se fosse considerado somente o traço nascer no Japão como traço distintivo da identidade étnica, os nisseis e sanseis também seriam considerados gaijins.

Em função do enunciado acima, serão produzidos mais dezenove enunciados que, de modo geral, buscam desqualificar os argumentos utilizados pelo enunciador que deu abertura ao tópico de discussão. Do total de respostas produzidas para o tópico, selecionei quatro que sintetizam as principais estratégias utilizadas como forma de refutar os argumentos apresentados pelo primeiro enunciado: 


\begin{tabular}{|c|c|c|}
\hline & Estratégia utilizada & Exemplos \\
\hline 01 & $\begin{array}{l}\text { Desqualificação do enunciador } \\
\text { Os enunciados agrupados nessa estratégia } \\
\text { utilizaram expressões pejorativas para denominar } \\
\text { o enunciador e perguntas retóricas, criando um } \\
\text { tom de ironia que visa a apontar para a incoerência } \\
\text { da produção do primeiro enunciado dentro da } \\
\text { comunidade Sou japa com (mto) orgulhu. }\end{array}$ & $\begin{array}{l}\text { jura? poxa ker mostrar q } \\
\text { entende das coisas? eheh } \mathrm{q} \\
\text { bom ngm aki ker saber o q vc } \\
\text { pensa. coisinha ridicula. } \\
\text { hahaha. japa = japa. sou } \\
\text { nissei/sanssei.. agora. o q issu } \\
\text { te importa?. nada. eehhe. se } \\
\text { vc ta nessa comunidade. entao } \\
\text { n coloke topicos assim } \\
\text { plz.bjxx e abrzz ;**ps: } 1^{\circ} \\
\text { comment;] }\end{array}$ \\
\hline 02 & $\begin{array}{l}\text { Desqualificação de argumento por } \\
\text { apresentação de contra-exemplo } \\
\text { Os enunciados agrupados nessa estratégia } \\
\text { buscaram contra exemplos para o argumento } \\
\text { apresentado na linha } 12 \text { (Sou muito mais cobicada } \\
\text { do que vcs,pq japones adora GAIJIN,a adora } \\
\text { MESTICOS e NEGROS tb!). }\end{array}$ & $\begin{array}{l}\text { Aff aff.. } \\
\text { como se vc fosse nhe..af af } \\
\text { af..e uma coisa.. } \\
\text { eu jah morei no Japão..qm } \\
\text { disse q eles adoramn } \\
\text { engros?eles sao racistas.. eles } \\
\text { judiam se algum negro vai pra } \\
\text { lá..vc nem sabe...eles judiam } \\
\text { dos mestiços tbm..eu naum } \\
\text { sofri isso pq sabia fala } \\
\text { japones..mais jah vi mtos } \\
\text { mestiços chegando do Brasil } \\
\text { naum sabendo fala japones e } \\
\text { sendo judiados.. }\end{array}$ \\
\hline
\end{tabular}




\begin{tabular}{|c|c|c|}
\hline 03 & $\begin{array}{l}\text { Desqualificação da argumentação pela } \\
\text { apresentação de outro argumento. } \\
\text { Os enunciados elencados nessa estratégia } \\
\text { buscaram apresentar outros argumentos na } \\
\text { tentativa de estabelecer o significado apresentado } \\
\text { na descrição da comunidade }\end{array}$ & $\begin{array}{l}\text { nossa mto nada vê nós somos } \\
\text { nihonjins plo q somo, ñ por } \\
\text { onde nascemos, tipo eu, eu } \\
\text { sou ninsei mtos me } \\
\text { consideram como nihonjin } \\
\text { msmo, td mto nada vê. }\end{array}$ \\
\hline 04 & $\begin{array}{l}\text { Adoção da palavra "Japa" para designar a } \\
\text { identidade étnica nipo-brasileira } \\
\text { Os enunciados agrupados nessa estratégia buscam } \\
\text { no título da comunidade o item lexical "japa" para } \\
\text { opor a "nihondin". Trata-se de uma estratégia } \\
\text { parecida com a anterior, mas, ao contrário dela, } \\
\text { não busca (re)estabelecer o significado da } \\
\text { descrição, ou seja, acaba criando uma nova } \\
\text { distinção. }\end{array}$ & $\begin{array}{l}\text { Nóis é JAPA.Se nóis fosse } \\
\text { NIHONJIN nóis não ia ser } \\
\text { japa.Porque japa é } \\
\text { descendente de nihonjin } \\
\text { nascido no Brasil.Como diz } \\
\text { aquela empresa de produtos } \\
\text { eletrônicos, "os nossos } \\
\text { japoneses são mais criativos } \\
\text { que os japoneses dos outros". } \\
\text { (apesar de não gostar do jeito } \\
\text { que eles dizem isso). E tenho } \\
\text { orgulho de ser especial. } \\
\text { Afinal sou diferente, como } \\
\text { todo mundo. hahahah! }\end{array}$ \\
\hline
\end{tabular}

Tabela 1

As quatro estratégias utilizadas para desqualificar o enunciado de abertura do tópico de discussão buscam definir a significação da identidade étnica nipo-brasileira, ora reforçando as representações veiculadas na descrição, ora propondo a designação de "japa" como forma de solucionar o conflito.

A descrição da comunidade busca reunir os elementos em torno de um conjunto que compartilha o predicado ter orgulho de ser Japa. Ao delimitar esse conjunto, pode- 
se depreender dos enunciados produzidos nessa comunidade virtual que a definição da identidade étnica faz emergir novamente uma ambivalência da representação desta identidade.

Assim, o significante orgulho, freqüentemente utilizado para marcar uma qualidade do povo japonês, ao mesmo tempo em que atualiza as representações de uma etnia ligada à suas origens, faz surgir significações que atribuem a esse significante marcas de preconceito.

Ao realizarem afirmações sobre a sua identidade étnica, os descendentes de imigrantes japoneses utilizam-se das representações veiculadas, no entanto, ao utilizálas se torna necessário amenizar as significações consideradas disfóricas. Esse jogo se torna mais saliente nos enunciados que colocam em jogo a identidade japonesa e brasileira, ao mesmo tempo. No que se segue, analisarei trechos de duas entrevistas realizadas com nipo-brasileiros:

1 Entrevistador: por que você acha que é uma brasileira japonesa e não uma

2 japonesa brasileira?

3 Informante 1: ah:: porque como eu tive bastante contato com descendentes que

4 consideram muito os japoneses ou com pessoas que moraram no Japão, pessoas

5 que se identificam muito com a cultura japonesa eu vi que eu gosto da cultura

6 japonesa, admiro vários aspectos da cultura japonesa, mas muitas coisas assim

7 eu não me identifico muito mais e também eu me identifico com várias coisas da

8 cultura que não é japonesa, né: da cultura brasileira não sei como definir a

9 cultura brasileira que é uma mistura.

No enunciado acima, a informante se apóia na representação que tem dos descendentes que consideram muito os japoneses (linhas 3 e 4) para se distanciar desse grupo. O distanciamento desse primeiro grupo passa, logo em seguida, para a cultura japonesa da qual seleciona vários aspectos para se identificar (linha 6). A introdução do quantificador vários (linha 7) cumpre a função de restringir os aspectos aos quais se identifica, o que pode ser indiciado em oposição ao quantificador muitas (linha 6) aplicado a coisas (anáfora de aspectos).

A informante procura afastar-se da representação de fanatismo que identifica no grupo elencado acima. Esta estratégia também pode ser indiciada por meio da construção do período mas muitas coisas eu não me identifico muito mais e também eu me identifico com várias coisas da cultura que não é japonesa (linhas 6-8). As conjunções mas e $e$ marcam, respectivamente, a necessidade de identificação com todos e somente com os aspectos da cultura japonesa. Nessa direção, declarar-se uma 
brasileira japonesa, ao mesmo tempo em que permite selecionar os traços que julga pertinente para a construção de sua identidade, (re)atualiza as representações negativas ligadas à identidade étnica do grupo.

No trecho em que o informante 2 se declara brasileiro e japonês, a tentativa de separação das representações se torna mais saliente:

1 Informante 2: eu acho que eu sou brasileiro porque eu falo demais porque eu me 2 relaciono demais com as pessoas assim na parte de abraçar, pegar coisas que 3 japonês não faz muito, mesmo com os melhores amigos assim você não vê um 4 japonês assim não faz muito, mesmo com os melhores amigos assim você não vê 5 um japonês assim abraçado, ou sei lá, fazendo coisas assim de contato físico 6 mesmo. Então nesta parte eu acho que eu sou mais brasileiro assim (...) na parte 7 bagunceira também e de preguiça ... e aí a parte japonesa que com as minhas 8 coisas eu sou organizado, aí já não depende do outro assim, é uma coisa mais 9 solitária assim eu já sou organizado eu tenho tipo meio que um $\{\ldots\}$ disciplina 10 para fazer as coisas e tal então nessa parte eu já me vejo mais japonês, algumas 11 coisas meio que invejo da parte japonesa e tal assim ensinamentos e tudo mais aí 12 tento aprender nessa parte eu sou mais oriental

No enunciado acima, o informante procura selecionar representações de duas identidades étnicas para definir a sua própria. É possível depreender uma simetria construída para amenizar os traços disfóricos. Assim, utiliza-se da declaração de ser brasileiro para contrapor-se às representações de frieza (em oposição a contato físicolinha 5/6) e mecanicidade (em oposição a bagunceiro- linha 7) atribuídas aos japoneses. Ao declarar-se japonês, o enunciador utiliza-se dos traços opostos organização (linha 9)e disciplina (linha 9) como componentes de sua identidade.

O entrevistado busca neutralizar as representações disfóricas com a divisão de uma identidade brasileira ligada ao convívio social e uma identidade japonesa restrita ao modo de organização pessoal. Assim sendo, novamente é possível observar uma predominância da mediação pela imagem. Não se trata da criação de uma identidade nipo-brasileira como síntese de duas etnias, mas da escolha em salientar traços de uma e de outra em relação às representações que circulam a respeito dos japoneses. 


\subsection{DA CIRCULAÇÃO DE REPRESENTAÇÕES Às DECLARAÇÕES DA IDENTIDADE ÉTNICA}

Este capítulo foi dedicado ao estudo dos efeitos de sentido produzidos pelas representações da identidade étnica do "japonês" e dos nipo-brasileiros veiculadas pela mídia e pelas entidades culturais. Pôde-se depreender dos enunciados veiculados pela mídia e pelos representantes de entidades culturais nipo-brasileiras a construção de um imaginário que combina a mediação pelos significantes e pela imagem. Essa construção faz com que a identidade seja estabelecida entre significante e objeto, sustentando uma ambivalência entre o sentido eufórico do significante e as representações disfóricas do objeto.

Nos enunciados circulados pela mídia, o emprego de significantes como laboriosa, bem-educada, que brilha, que remetem a características da identidade étnica do japonês, aparecem relacionados ao objeto, designado como exército e maioria esmagadora, o qual contém traços considerados disfóricos. Já nos enunciados produzidos pelos representantes de entidades nipo-brasileiras, o jogo é estabelecido entre um ideal, tipicamente nihondin, e as características físicas dos descendentes, como forma de suplantar o desaparecimento dos traços biológicos.

Por meio da análise dos enunciados produzidos por descendentes de imigrantes japoneses, foi possível depreender uma construção da identidade pautada, predominantemente, pela imagem. Busca-se aderir aos significantes considerados eufóricos e inserir enunciados que possam modificar as representações disfóricas associadas a esses significantes. Esse modo de construção faz com que os enunciados se tornem uma disputa pelo significado das palavras e não uma declaração a respeito da identidade étnica dos membros do grupo.

No capítulo que se segue, continuarei a análise de declarações que buscam delimitar uma identidade. Tomarei como objeto os enunciados que portam declarações a respeito da linguagem utilizada pelos imigrantes japoneses para depreender as representações associadas a essa linguagem. 


\section{AS REPRESENTAÇÕES DA LINGUAGEM: ESTUDO DAS DECLARAÇÕES SOBRE A LÍNGUA}

Este capítulo tem como objetivo depreender as representações associadas à identidade da linguagem utilizada pelos imigrantes japoneses. De maneira semelhante ao capítulo anterior, partirei da definição de identidade lingüística a ser empregada neste trabalho e, posteriormente, para a análise de enunciados produzidos na comunidade virtual Eu falo batyanês que buscam caracterizar a linguagem utilizada pelos imigrantes.

\subsection{A IDENTIDADE LINGÜÍSTICA FRENTE À REALIDADE PLURILINGÜÍSTICA}

A noção de identidade lingüística pode parecer incongruente com um trabalho que tem como referência as concepções de linguagem elaboradas no âmbito da Análise do Discurso, área da lingüística que postula a impossibilidade de transparência da linguagem. Pêcheux (1983), ao abordar o desenvolvimento da Análise do Discurso, pontua que uma das tomadas de posição que se mantém é a "recusa de qualquer metalíngua universal supostamente inscrita no inatismo do espírito humano, e de toda suposição de um sujeito intencional como origem enunciadora de seu discurso" (op. cit. p. 311). No entanto, é importante considerar que a própria elaboração teórica dos estudos do discurso surge como oposição à idéia de identidade da linguagem com si mesma ou com o mundo.

Rajagopalan (2001) realiza uma revisão das vertentes da Lingüística e o modo como elas consideraram a relação entre identidade e as idéias de uma língua e falante de uma língua. Para o autor, a lingüística moderna se funda como uma ciência ao considerar estas idéias como pacíficas, semelhantemente ao modo como um leigo as considera.

Em contrapartida à idéia de falante de uma língua com uma identidade fixa, Rajagopalan indica a necessidade de reconsiderar esses pontos levando em consideração 
fenômenos como multilingüismo, pidgins, línguas de sinais etc., que indiciam a falta de limites existentes para o que é considerado como uno. Para o autor:

Talvez a próxima grande revolução na lingüística resulte da constatação, por parte dos teóricos, de que muitos dos incontroláveis fenômenos que desafiam as teorias contemporâneas só começarão a fazer sentido, ao que tudo indica, quando começarmos a levar seriamente em conta a possibilidade de identidades proteiformes e, quem sabe, das identidades "vira-latas" de Rushdie, o que significa identidades em permanente estado de fluxo. (op.cit.: 42)

A suposta facilidade com que se pode identificar uma língua também é o ponto escolhido por Vermes \& Boutet (1989) para a apresentação do livro Multilingüismo. Trata-se de uma obra que reúne textos de diferentes abordagens, que procuram problematizar o ideal monolíngüe face às práticas lingüísticas e as representações construídas em torno da idéia de língua materna.

\footnotetext{
A prática das misturas das línguas coloca de maneira crucial a questão da autonomia dos sistemas linguísticos e a da fronteira entre as línguas. Mas estes questionamentos não são atributos dos pesquisadores: os locutores, mergulhados em situações de contato de línguas, onde a hibridação é praticada assim que sancionada, são também confrontados, em particular quando conduzidos a emitir julgamentos ou a falar de suas práticas: como nomear as línguas que se falam nestas situações? (op. cit.: 14)
}

Para os autores, a realidade multilíngüe interroga o emprego da noção de língua materna como conceito descritivo ou explicativo, ao mesmo tempo em que obriga a lançar mão de modelos teóricos a partir dos quais se pode conceber a relação estabelecida entre a língua materna e as outras línguas (op. cit.: 11).

As considerações expostas por Rajagopalan (2001) e Vermes e Boutet (1989) interessam a esse trabalho na medida em que apontam para a necessidade de ultrapassar a noção de língua como um sistema idêntico a si mesmo diante da diversidade observável nas produções lingüísticas. Esta posição é a que a Análise do Discurso considera constitutiva de toda produção lingüística e não somente em contextos de línguas em contato.

Ainda é preciso considerar que a despeito da multiplicidade das produções lingüísticas, os falantes constroem discursos públicos sobre a língua, constituído por impressões e julgamentos dos falantes que, ao mesmo tempo em que delimitam um falar, constituem forças que atuam sobre a produção lingüística como um todo (SCHLIEBEN-LANGE, 1993). Ao abrir espaço para considerar as influências das 
diversas atividades sobre o falar, a autora favorece uma investigação que busca considerar as relações entre aquele que fala e a língua, juntamente com o conhecimento que esse falante manipula em sua ação.

\subsection{IDENTIDADE LINGÜÍSTICA COMO MANIFESTAÇÃO FRENTE ÀS NÃO-COINCIDÊNCIAS DO DIZER}

Para uma aproximação da noção de identidade lingüística que pretendo construir para esta dissertação, torna-se relevante a consideração dos trabalhos elaborados por Authier-Revuz (1984, 1993, 1998a e 1998b) acerca das atividades linguageiras de auto representação do dizer pelo enunciador (1998b:177). Nesses trabalhos, a autora se dedica a descrever as operações discursivas que um sujeito opera ao tomar o dizer como objeto que pode ser representado no interior de um enunciado.

Em seu texto Heterogeneidade(s) Enunciativa(s) (1984), a autora se dedica à diferenciação entre o que denomina de heterogeneidade constitutiva e heterogeneidade mostrada, sendo que a segunda pode-se realizar de forma marcada (por meio do discurso direto, das aspas, dos itálicos, dos incisos de glosas) e de forma não marcada (por meio do discurso indireto livre, da ironia, do pastiche, da imitação).

\footnotetext{
Heterogeneidade constitutiva do discurso e heterogeneidade mostrada no discurso representam duas ordens de realidade diferentes: a dos processos reais de constituição de um discurso e a dos processos não menos reais, de representação, num discurso de sua constituição.

Não se trata de assimilar um ao outro, nem de imaginar um relacionamento simples de imagem, de tradução, nem de projeção de um no outro; essa relação de correspondência direta é interditada tanto porque ela faria supor uma transparência do dizer em suas condições reais de existência quanto pela irredutibilidade manifesta das duas heterogeneidades. (op. cit.: 32)
}

Authier-Revuz considera as manifestações da heterogeneidade mostrada, em suas formas marcada e não marcada, como mecanismos discursivos que visam a restabelecer a ilusão de um "eu pleno" senhor de seu dizer. Para a autora, a construção dessas representações constituem formas de proteção ilusórias para que um discurso possa ser sustentado face à heterogeneidade constitutiva de toda enunciação.

Assim essa representação da enunciação é igualmente "constitutiva", em um outro sentido: além do "eu" que se coloca como sujeito de seu discurso, "por esse ato individual de apropriação que introduz aquele que fala em sua fala", as formas marcadas da heterogeneidade marcada reforçam, confirmam, asseguram esse "eu" por uma especificação de identidade, dando corpo ao 
discurso - pela forma, pelo contorno, pelas bordas, pelos limites que elas traçam - e dando forma ao sujeito enunciador - pela posição e atividade metalingüística que encenam (op. cit.: 33)

Diante da percepção de possíveis desvios de sentido - heterogeneidade mostrada - o enunciador se utiliza de recursos que buscam representar esses outros sentidos, no entanto, a encenação desses sentidos também se realiza por uma enunciação, que é constitutivamente heterogênea.

Essas considerações se tornam importantes para avançar na construção da noção de identidade lingüística, pois, ao considerar fenômenos lingüísticos como os apontados por Rajagopalan (2001) - multilingüismo, pidgins, línguas de sinais etc - é preciso considerar que a identidade lingüística não se encontra ameaçada exclusivamente pelos fenômenos de contato, mas também pela heterogeneidade constitutiva de toda enunciação.

Nos trabalhos seqüentes (em especial, 1993 e 1998b), Authier-Revuz continua sua investigação acerca das formas de representação do dizer tomado como objeto, o qual não é mais capaz de se representar na linearidade transparente de um enunciado. A autora considera que as representações metaenunciativas como forma de contorno das não-coincidências podem ser tidas como um encontro que eles (enunciadores) fazem localmente - em seu dizer, com diversas não coincidências, e da "resposta que eles fornecem a elas (op. cit., 1993: 21).

\footnotetext{
Manifestas na superfície do dizer, as glosas metaenunciativas não são da ordem do ornamento: através dessas formas que testemunham o modo segundo o qual um dizer "se mantém" no jogo dispersante das nãocoincidências, elas são, para um sujeito que é sujeito a ser falante, ou seja, a ser tomado na linguagem, jogos essenciais que se jogam, tocando de modo singular o ser na linguagem, que é, particularmente, modo singular de "se colocar" em, ou de "fazer com" suas não coincidências e com o que elas inscrevem de divisão fundadora e de ameaça do esfacelamento (déliaison) no âmago do sujeito e do sentido. (op. cit., 1998b: 192)
}

Ao analisar os comentários metaenunciativos (1993, 1998b), a autora propõe quatro formas da manifestação de representações sobre as não-coincidências do dizer que buscam construir o $U M$ imaginário, que visa a assegurar a coesão entre significado e significante. A partir do encontro local dessas formas metaenunciativas, nomeadas de modalizações autonímicas, com a heterogeneidade constitutiva, as não-coincidências são classificadas como: 


\section{a- Não coincidência interlocutiva}

Aparece representada em enunciados como digamos $X$, permita-me $X$, se você quiser, eu bem sei que você não gosta da palavra etc. É sustentada pela noção freudiana de inconsciente que postula que dois sujeitos não são iguais entre si. As representações produzidas nesta categoria buscam, a partir do imaginário do enunciador, explicitar que um determinado sentido não é partilhado pelo interlocutor, ou, responder ao sentido esperado na compreensão de um locutor.

\section{b- Não-coincidência do discurso consigo mesmo}

As representações buscam traçar uma fronteira interior/exterior podendo variar do apagamento de toda exterioridade (discurso totalitário) ou ser representado totalmente pelo exterior (cópia). Tem como referência a noção bakhtiniana de dialogismo e a teorização do interdiscurso de Pêcheux. A primeira postula que a produção lingüística se dá sob um já dito, carregando os sentidos produzidos ao longo da história, e a segunda pontua uma determinação externa que é apagada para a criação de um "eu falo", quando na verdade os sentidos são construídos historicamente.

\section{c- Não-coincidência entre as palavras e as coisas}

Esta categoria é depreendida de enunciados que criam três tipos de representações: 1) Figuras do Um, buscando criar a coincidência entre palavra e coisa ( $X$ é a palavra exata, $X$, no sentido estrito etc); 2) Busca-se a adequação entre "o dizer e o não dizer" (isso que se poderia chamar X; não digo X, mas quase); e 3) Representa-se a falta da nomeação seja pela suspensão, anulação ou imperfeição da relação entre palavra e coisa respectivamente (se se pode dizer, eu não diria $X$ que, $X$ por falta de palavra melhor). Trata-se de uma categoria considerada constitutiva em duas perspectivas, a saber, na impossibilidade de se nomear as infinitas singularidades do real por meio do conjunto finito de unidades discretas da língua (MILNER:1978) e na concepção lacaniana de real como radicalmente heterogêneo à ordem simbólica. 


\section{d- Não-coincidência das palavras consigo mesmas}

Essa categoria agrupa enunciados que testemunham o encontro do enunciador com o equívoco seja por: 1) fixarem um sentido ( $X$, no sentido de $p ;, X$ sem jogo de palavra); 2) alterar o sentido pelo encontro com o não-um (seria preciso dizer $X, X$ se ouso dizer); 3 ) estender o sentido no não-um ( $X$, também no sentido de q); e 4) Reassegurar o dizer pelo não-um (X, é o caso de dizer, X esta é a palavra). O suporte teórico é buscado no conceito de lalangue, cunhado por Lacan para representar a dimensão do equívoco como constitutivo da linguagem, estando relacionado com os efeitos de homonímia, o cruzamento dos sentidos sobre o som.

Authier-Revuz (1993, 1998b) parte da investigação de enunciados denominados de modalizações autonímicas, que buscam contornar o encontro com o não-um, para construir um aparato teórico a partir do qual é possível discriminar a representação do encontro com o não-um de sua expressão transparente. Essa diferenciação é importante para este trabalho uma vez que os enunciados que serão analisados buscaram definir os contornos da fala de imigrantes japoneses, ou seja, a construção dessas representações também constitui uma atividade pela qual se busca controlar o dizer e nomear um objeto de língua.

\subsection{IDENTIDADE LINGÜÍSTICA VERSUS LÍNGUA MATERNA}

Postular a língua como não idêntica a si mesma não anula a tentativa por parte dos falantes de construírem representações que possam dar o contorno do que é uma determinada língua. Seguindo o raciocínio desenvolvido nos trabalhos de Authier-

Revuz (1984, 1993, 1998a e 1998b), é possível afirmar que a permissão para a construção dessas identidades lingüísticas deve-se justamente ao fato das nãocoincidências serem constitutivas da língua.

Wald (1989) busca compreender a construção da língua materna como um produto da caracterização social. A noção apresentar-se-ia como um modelo a partir do qual o sujeito pode categorizar sua própria identidade linguiística em meio à pluralidade do contexto sociolingüístico, seja para aderir ou se contrapor a uma determinada representação. 
Pode-se então, concluir que a liberdade do sujeito de colocar em ação um ideal unilíngüe da identidade lingüística não é dificultada pela impossibilidade de subordinar o repertório de sua comunidade a uma língua única. De fato, o plurilinguismo generalizado e seu próprio plurilinguismo não o impedem, necessariamente, de construir opções de categorização que marginalizam, de uma maneira mais ou menos transitória, setores inteiros do repertório comum. (op. cit.: 106-107)

Assim, neste trabalho considero identidade lingüística como um conjunto de declarações a respeito da língua que buscam representá-la como UM, ou seja, a tentativa de reunir sob o escopo de um nome a multiplicidade das realizações lingüísticas. Seguindo essa linha de raciocínio, a noção de língua materna também pode ser considerada uma identidade lingüística na medida em que instaura a idéia de que, ao lado das línguas de cultura, existem usos diferentes, mas importantes, adquiridos naturalmente em um dado espaço geográfico (DECROSSE, 1989:19).

Decrosse (1989) resgata a construção da noção de Francês como língua materna ao partir de um ambiente plurilíngüe até chegar a uma idéia de que existe um país monolíngüe. Este processo encontra-se associado com a relação criada pela apropriação por parte do Estado de uma língua que fica como sendo a responsável por representar o país.

Essa apropriação pelo poder real, que se irá acentuando até atingir o ideal monolíngüe do século XVII, sobre a questão do falar natural reorganiza o mito: daí em diante, as línguas maternas só terão de combater a língua de cultura, pois uma língua materna tornou-se oficial no território da França. O mito está completo, a língua materna é única e unificante. (op. cit.: 27)

A escolha do emprego do termo identidade lingüística para referir-se às diferentes representações construídas pelos falantes, assim, não aparece em contraposição à noção de língua materna tal como apresentada por Wald (1989) e Decrosse (1989), uma vez que esta seria uma das possíveis representações construídas.

No entanto, pode-se contrapor o termo identidade lingüística com a noção de língua materna tal como desenvolvida na psicanálise de orientação lacaniana, que relaciona a língua materna ao domínio do conceito de lalangue ${ }^{13}$. Essa é a noção na qual

\footnotetext{
${ }^{13} \mathrm{O}$ termo lalangue é cunhado por Lacan para designar aquilo que escapa à univocidade da nomeação, apontando para o registro que, em toda a língua, a consagra ao equívoco.
} 
Authier-Revuz (1993, 1998b) se apóia para teorizar a não-coincidência das palavras com elas mesmas.

Trata-se do campo que postula que por meio dos equívocos, das homofonias se produz uma quebra na linearidade do enunciado que permite depreender um posicionamento do sujeito.

Só que, uma coisa é clara, a linguagem é apenas aquilo que o discurso científico elabora para dar conta do que chama alíngua.

Alíngua ${ }^{14}$ serve para coisas inteiramente diferente da comunicação. É o que a experiência do inconsciente mostrou, no que ele é feito de alíngua, essa alíngua que vocês sabem que eu escrevo numa só palavra, para designar o que é a ocupação de cada um de nós, alíngua dita materna, e não por nada dita assim. (LACAN, 26 de junho de 1973)

A distinção entre língua materna como uma das possibilidades de manifestação de uma identidade lingüística e de língua materna como suporte para lalangue torna-se produtiva para depreender as ações empreendidas pelos falantes na tentativa de estabelecer as representações que buscam estabelecer a identidade do não-um.

\subsection{A REPRESENTAÇÃO DA LÍNGUA FALADA PELO IMIGRANTE JAPONÊS: O BATYANÊS}

Iniciarei a análise das representações associadas à fala dos imigrantes de japoneses pelos enunciados produzidos na comunidade virtual Eu falo Batyanês para, posteriormente, passar à análise dos enunciados produzidos nas entrevistas. Esta escolha justifica-se pelo caráter metalingüístico assumido tanto pela descrição da comunidade quanto pelos enunciados produzidos nos tópicos.

O caráter metalingüístico pode ser percebido pela utilização de termos relacionados com os estudos lingüísticos e pelo modo como busca realizar a definição do significado de Batyanês. Ainda é preciso considerar que essa definição apresentada na descrição da comunidade ocupa o lugar de explicitação do título da mesma, Eu falo Batyanês, funcionando como explicação para a nomeação da comunidade.

No próprio título da comunidade, é possível depreender traços de heterogeneidade mostrada não-marcada, uma vez que, apesar de não haver inserção de elementos que indiquem o sentido que o enunciador deseja explicitar, a nomeação batyanês incide sobre a fala enquanto objeto exterior ao próprio enunciado.

\footnotetext{
${ }^{14}$ Trata-se da tradução do termo lalangue para o português.
} 
Transcrevo abaixo o enunciado de descrição da comunidade:

1 Eu falo Batyanês

2 Batyanês é aquele mix de nihongô + português + nihongô falado com sotaque

3 português + português falado com sotaque de nihongô. Uma salada que nem você

4 nem a sua batyan acabam entendendo, mas ficamos sorrindo fingindo que

5 entendemos para agradar um ao outro. Quem não fala esse "idioma" todos os

6 domingos quando você vai visitar a batyan? Essa comunidade criada para

7 integração e uniformização do vocabulário que foi criado graças às nossas

8 queridas velhinhas!

A comunidade tem como tema o falar da Batyan, palavra que na língua japonesa designa a avó. No entanto, observa-se que a figura da avó é escolhida como figura representante da imigração japonesa para o Brasil, incluindo sob esta designação o falar das pessoas cuja fala possui traços que remetam à identidade da língua japonesa.

A própria divisão entre a língua da avó e a língua dos netos torna-se significativa para pensar as representações colocadas em jogo pela existência da comunidade, uma vez que marca a distância entre a identidade lingüística dos membros da comunidade (os netos) e aquela falada pela avó. É a cultura daquela que já foi mãe que é colocada como limite por uma geração que não se posiciona mais como filhos, ou que, pelo menos, já não considera esta língua como sendo a língua dos pais.

$\mathrm{Na}$ descrição, pode-se observar a incorporação de elementos que remetem para outras identidades lingüísticas, em especial, a língua japonesa, por meio dos itens lexicais nihongo (linha 2) e batyan.(linha 4) Esses itens seguem o mesmo padrão (ortográfico e morfossintático) do restante do enunciado que, em contraposição à remissão à identidade da língua japonesa, torna-se representante da identidade lingüística da língua portuguesa. A nomeação do idioma é feita pela aglutinação do item “Batyan”, que se refere à avó, com os dois últimos fonemas da palavra português.

Ainda é interessante observar a demarcação desses usos junto ao ambiente familiar, relacionando com a figura da avó, termo que em todo o enunciado é substituído pelo item que remete à identidade da língua japonesa, “Batyan”, que não só expressa a mãe de um dos pais, mas também é valorado afetivamente, visto que a única substituição no enunciado foi realizada pelo sintagma “queridas velhinhas” (linha 8).

De algum modo, a apresentação atualiza uma relação afetiva ambivalente, pois, ao mesmo tempo em que mantém uma relação afetuosa com "a querida velhinha", 
também põe em dúvida a própria relação, questionando a comunicação estabelecida entre os membros da comunidade e os imigrantes japoneses:

Uma salada que nem você nem a sua batyan acabam entendendo, mas ficamos sorrindo fingindo que entendemos para agradar um ao outro.

Este enunciado inicia caracterizando a língua com o sintagma "uma salada" cujo efeito é a não compreensão mútua, que resulta em uma relação de aparência. É exatamente no momento em que passa a relatar os efeitos dessa salada que aparece a voz do enunciador marcada pelo uso da primeira pessoa do plural.

Os movimentos de aproximação e distanciamento dessa voz do enunciador indiciam uma relação de particularização dessa relação estabelecida pelo batyanês: inicia-se o enunciado com um modelo de definição, utilizando o verbo ser na terceira pessoa do singular, que faz com que esta voz seja afastada e atribuída à terceira pessoa. (Batyanês é aquele mix de nihongô+português+nihongô falado com sotaque português+ português falado com sotaque de nihongô. Uma salada que nem você nem a sua batyan acabam entendendo).

$\mathrm{Na}$ seqüência do último período acima, observa-se a utilização da primeira pessoa do plural que ao mesmo tempo em que retoma o leitor (você), inclui a voz do enunciador. Se em um primeiro momento este enunciador estava fora do contexto, apagando sua voz para poder realizar uma descrição, não permanecerá fora dos efeitos dessa fala, pois termina o enunciado questionando a possibilidade de se manter alheio a esta situação "Quem não fala esse "idioma" todos os domingos quando você vai visitar a batyan".

A particularização do batyanês ao contexto familiar, associada à figura da avó, juntamente com os movimentos de afastamento do enunciador para realizar a descrição metalingüística e aproximação nos momentos em que precisa utilizar esta língua, estabelece a relação dos membros da comunidade em duas instâncias diferentes: a) com relação à avó, dona de um falar com características próprias; e b) com relação ao grupo cujo falar se relaciona com a identidade lingüística da língua portuguesa.

Os membros da comunidade são aqueles que, apesar de conseguirem estabelecer a comunicação com o grupo representante dos imigrantes japoneses, não se inscrevem dentro deste. É essa inscrição que autoriza os membros da comunidade a realizarem a descrição e o julgamento da linguagem da avó. 
Para uma aproximação dos julgamentos e das representações associadas à identidade lingüística dos imigrantes de japonês, analisarei os enunciados produzidos no tópico de discussão nomeado de:

1 Palavras engraçadas da Batyan

2 Ok, nossas batyans tem algo muito em comum... o batyanes, agora vamos

3 escrever as palavras ou termos mais engraçados que sua Batyan fala. Vamos

4 compartilhar a linguagem delas.

Novamente, observa-se a distinção das gerações, contrapondo um nós (netos) VS um ela (Batyan). É interessante observar a utilização dos pronomes possessivos antepostos a Batyan (linha 2): ao mesmo tempo em que é estabelecida uma relação entre as gerações, é criada uma categoria na qual essas gerações podem ser representadas distintamente, separando a identidade lingüística atribuída à avó da identidade lingüística desta geração. A construção sustenta a imagem segundo a qual a utilização do batyanês está reservada às avós, não fazendo parte da identidade lingüística dos falantes.

Trata-se do tópico com mais comentários produzidos na comunidade virtual. Para a análise que apresento neste capítulo, foram considerados 204 (duzentos e quatro) enunciados elaborados em virtude da proposta de tópico exposta acima. O primeiro elemento que marca a produção desses enunciados é o riso, sendo expresso por algum elemento explicitamente em 172 (cento e setenta e dois) enunciados, enquanto os outros acabam partilhando, em especial, pela ironia do escopo de engraçado utilizado no enunciado que dá início ao tópico.

Ao observar os enunciados produzidos dentro deste tópico, é possível distinguir o momento de descrição da linguagem da avó e um momento no qual é realizado o julgamento desta linguagem. Para fins de análise das representações, optei por separar a descrição dos elementos que compõem a identidade lingüística do batyanês dos julgamentos realizados a partir dessa linguagem. Esta decisão foi feita por considerar que a manifestação dos dois elementos em um mesmo enunciado abre espaço para investigar, além das representações criadas pelas modalizações autonímicas, as atividades exercidas pela linguagem por meio de diferentes enunciadores em um enunciado (DUCROT: 1984), investigação que será realizada no próximo capítulo. 


\subsection{A REPRESENTAÇÃO DO NÃO-UM DA IDENTIDADE LINGÜÍSTICA DO} BATYANÊS

Podem-se distinguir dois componentes importantes na construção da representação da identidade lingüística dos imigrantes japoneses: o primeiro refere-se aos itens lingüísticos escolhidos para circunscrever a representação do não-um e o segundo às estratégias utilizadas para apresentar os índices que possibilitam o reconhecimento do que é nomeado, pelos membros da comunidade, de batyanês.

$\mathrm{O}$ ato de nomear a fala dos imigrantes japoneses cria uma identidade lingüística cujo principal contraponto é uma identidade lingüística por meio da qual a comunicação poderia acontecer sem interferências. Para facilitar a análise, apresentarei primeiro os indícios lingüísticos que os membros da comunidade virtual elencaram para o reconhecimento da identidade lingüística do batyanês para, depois, expor as estratégias utilizadas para a apresentação desses indícios.

Apresento, na tabela a seguir, os índices elencados pelos membros da comunidade como forma de reconhecimento da identidade lingüística do batyanês, buscando distinguir o nível de análise lingüístico em que esses elementos são produzidos e a forma como podem interferir na identidade lingüística considerada como ideal de comunicação.

\begin{tabular}{|c|c|c|}
\hline & Nível Lingüístico da Interferência & Exemplos: \\
\hline 01 & $\begin{array}{l}\text { Índices fonéticos: É o nível mais apontado pelos } \\
\text { membros da comunidade. Refere-se à produção dos } \\
\text { sons por parte dos imigrantes. Busca-se marcar o } \\
\text { estranhamento na produção de alguns fonemas em } \\
\text { que os imigrantes empregam sons que } \\
\text { corresponderiam à realização de um outro fonema, } \\
\text { considerando as distinções da língua portuguesa. Os } \\
\text { elementos elencados nesse nível apontam para não- } \\
\text { coincidência do som com o fonema, mas não } \\
\text { interferem na significação. }\end{array}$ & $\begin{array}{l}\text { RUUPI = Loop (meu dog) } \\
\text { ovo ! obo } \\
\text { fezes ! fezus } \\
\text { bobo ! bôbÔ }\end{array}$ \\
\hline
\end{tabular}




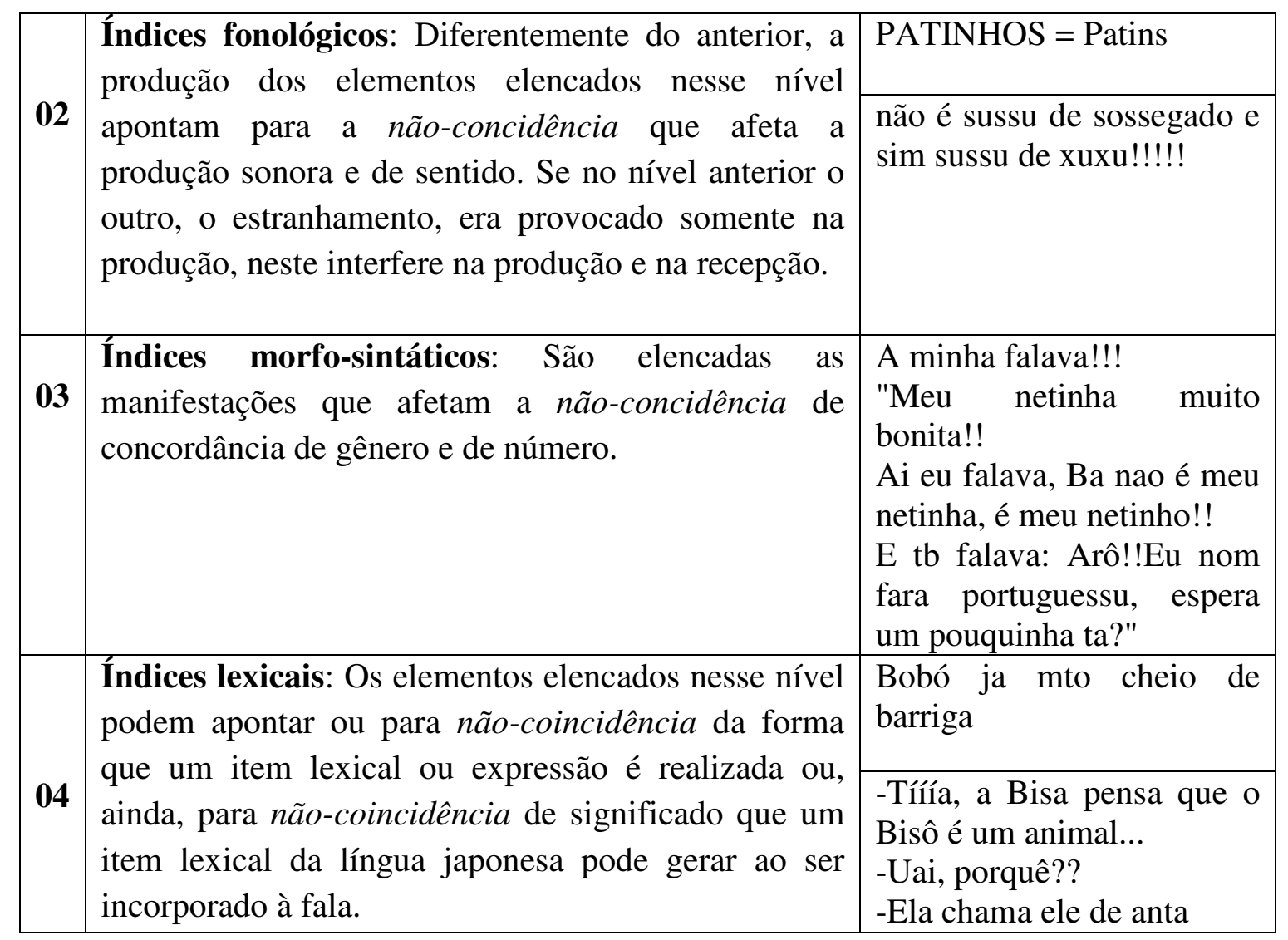

Tabela 2

Além dos quatro tipos de índices elencados na tabela acima, é possível encontrar enunciados que apontam para as não-coincidências pragmáticas e textuais. Os enunciados a partir dos quais é possível depreender índices pragmáticos e textuais são diálogos em que os outros elementos elencados acima também aparecem. No diálogo a seguir, é possível observar um índice do nível pragmático:

1 ela pega o telefone..

2 alguem: quem tah falando?

3 batiam: eu tô farandô!

4 alguem:quem????

5 batiam: EU TÔ FARANDÔ

O trecho reproduz um diálogo por telefone em que o enunciado quem fala? não é interpretado dentro do jogo conversacional no qual é produzido. Ao mesmo tempo, é possível observar marcas fonéticas (a troca da alveolar/ lateral [1] pela alveolar vibrante [r]) e a utilização do recurso gráfico $\left\{{ }^{\wedge}\right\}$ para marcar uma prosódia da identidade lingüística dos imigrantes japoneses (linhas 3 e 5). 
No diálogo a seguir, também é possível observar o mesmo mecanismo, no entanto, este serve como exemplo de um índice textual:

1 o di ligou pro meu pai

2 Di: gerardo, tem que buscá corega.

3 pai: que colega o pai quer q eu vou buscar?

4 Di: o corega, gerardo!

5 pai: mas q corega, di? onde q ele mora?

6 Di: na farumáxia, gê!

7 pai: na farmácia, pai? q colega é esse? é de ibiúna?

8 Di: nooon, gerardo! pára di sê buro! é corega da dentadura do di

9 pai: aaaah, ta bom pai.

10 Di: ta...

11 pai: pai?

12 -tututu

O diálogo gira em torno do estabelecimento do referente de corega que, a princípio, só tem referência fora do enunciado, ou seja, o único que possuía a informação é o interlocutor di (forma afetiva para ditchan - avô) que, no entanto, não percebe a necessidade de estabelecer o referente no próprio enunciado. Novamente, observa-se a manifestação de outros índices que marcam a identidade lingüística dos imigrantes japoneses: índices fonéticos (linhas 2, 6 e 8) e índice morfossintático (linha 2, não realização do determinante no sintagma nominal corega).

A sobreposição desses índices torna-se significativa para pensar a identidade lingüística atribuída aos imigrantes japoneses, porque coloca em um mesmo plano índices ligados à linguagem e índices ligados ao desempenho do falante, relação que será retomada no momento em que os membros da comunidade realizam julgamentos sobre a linguagem dos imigrantes. A utilização dessa língua molda, ao mesmo tempo, uma identidade lingüística e uma identidade para o falante dessa língua.

Os índices acima foram depreendidos dos enunciados produzidos no tópico palavras engraçadas da batyan. A partir da leitura desses enunciados, puderam-se distinguir cinco estratégias de apresentação da fala do imigrante japonês. Essas estratégias estão elencadas na tabela que se segue: 


\begin{tabular}{|c|c|c|}
\hline & Estratégia utilizada & Exemplos \\
\hline 01 & $\begin{array}{l}\text { Lista de palavras: Nesta categoria, foram } \\
\text { elencados os enunciados que buscaram criar uma } \\
\text { lista de palavras a partir da qual seria possível a } \\
\text { identificação do Batyanês. Essas listas podem } \\
\text { trazer apenas os itens lexicais representantes da } \\
\text { identidade lingüística atribuída ao imigrante e } \\
\text { também pode aparecer com a tradução para o que } \\
\text { seria a língua dos membros da comunidade virtual. }\end{array}$ & $\begin{array}{l}\text { alo! Arô! } \\
\text { ovo ! obo } \\
\text { fezes! fezus } \\
\text { bobo ! bôbô } \\
\text { arutisto=artist } \\
\text { sussu - хихu }\end{array}$ \\
\hline $\mathbf{0 2}$ & $\begin{array}{l}\text { Reprodução da fala do imigrante: Nesta } \\
\text { categoria, encontram-se os enunciados que } \\
\text { buscam se apresentar a partir da posição do } \\
\text { imigrante. Busca-se representar a identidade } \\
\text { lingüística por meio da construção de enunciados } \\
\text { que sirvam como registro da fala do Batyanês. }\end{array}$ & $\begin{array}{lcr}\text { BATIAN NON KÉ } & \text { RÓTO! } \\
\text { BATIAN NON TIRA RÓTO! } \\
\text { BATIAN BAI BARE } & \text { KAZA, } \\
\text { RIMPÁ } & \text { TUDO, } & \text { ABRI } \\
\text { DJANERA } & \text { PRA } & \text { ENTURA } \\
\text { BENTO! } & & \\
\text { BATIAN NON BAI } & \text { FAZE } \\
\text { MACARONDINHO } & C O M \\
\text { CARUNE, BATIAN } & \text { BOA } \\
\text { MEMO! } & & \end{array}$ \\
\hline 03 & $\begin{array}{l}\text { Apresentação da fala pelo enunciador: Esta } \\
\text { categoria difere da anterior pela introdução da voz } \\
\text { do enunciador que busca explicitar a fala do } \\
\text { imigrante inserindo informações sobre o contexto } \\
\text { em que aparece. }\end{array}$ & $\begin{array}{l}\text { ela fala macarron...netinho } \\
\text { prás meninas e netinha } \\
\text { prosmeninos... }\end{array}$ \\
\hline 04 & $\begin{array}{l}\text { Reprodução de diálogos: Os enunciados desta } \\
\text { categoria buscam evidenciar a fala do imigrante e } \\
\text { as dificuldades de estabelecer a comunicação com } \\
\text { eles. }\end{array}$ & $\begin{array}{l}\text { EU: BACHIYAN O Q TEM } \\
\text { PRAH COMERR??? } \\
\text { BACHIYAN, TABERUNI } \\
\text { NANI ARU??? } \\
\text { ELA: DJIRINDJERA.... }\end{array}$ \\
\hline 05 & $\begin{array}{l}\text { Narração de Episódios: Esta categoria difere da } \\
\text { anterior porque os diálogos dão ênfase aos } \\
\text { episódios anedóticos e não somente à fala do } \\
\text { imigrante. }\end{array}$ & $\begin{array}{l}\text { Ligo para o meu pai: } \\
\text { - Alô, papai! Aqui é Aristein! } \\
\text { - Arô!! Quem? } \\
\text { - Aristein!!! } \\
\text { - Non, Aristein non esta!!! (e } \\
\text { desliga na hora!) }\end{array}$ \\
\hline
\end{tabular}


A partir das estratégias elencadas acima, pode-se observar que os índices fonéticos, fonológicos e morfossintáticos são apresentados pelas estratégias 1, 2, 3 e 4, enquanto os índices pragmáticos e textuais são apresentados pela estratégia 5. Essa última estratégia diferencia-se das outras porque escolhe para apresentação episódios que se aproximam de anedotas causadas pelos índices de não-coincidência dos diversos níveis lingüísticos.

A escolha pela apresentação de índices pragmáticos e textuais, em que o desempenho do falante não está vinculado com a linearidade do enunciado por meio de episódios anedóticos, atribui essa representação (cômica) para os outros índices lingüísticos. Essa linha de interpretação ganha força ao atentar-se para os julgamentos que os membros da comunidade realizam sobre a identidade lingüística do batyanês que, na maioria das vezes, são declarações que incidem sobre o próprio imigrante japonês.

Cria-se, portanto, uma simetria entre a identidade do imigrante e a identidade do batyanês, em que uma das identidades serve como forma de explicação da existência da outra. Em relação aos enunciados que apresentam as não-coincidências do nível pragmático e textual, pode-se afirmar que os índices dos níveis lingüísticos, passíveis de serem reconhecidos na linearidade do enunciado, provocariam o surgimento dessas nãocoincidências e, por conseqüência, o efeito cômico.

\subsection{REPRESENTAÇÕES DOS VALORES ATRIBUÍDOS À IDENTIDADE LINGÜÍSTICA DOS IMIGRANTES JAPONESES}

A característica mais salientada pelos integrantes da comunidade virtual com relação à identidade lingüística da fala dos imigrantes é o seu efeito cômico que aparece marcado em 172 (cento e setenta e dois) dos 204 (duzentos e quatro) enunciados que constituem o tópico. Acrescenta-se, ainda, que o próprio título escolhido para o tópico, palavras engraçadas, aponta para a predominância desse valor na identidade lingüística do batyanês.

Como apresentado no item anterior, essa identidade lingüística visa a circunscrever as diversas não-coincidências como causa do efeito cômico proveniente da fala dos imigrantes japoneses. Nesse item, apresentarei as declarações a partir das quais é possível depreender representações associadas à identidade lingüística dos 
imigrantes de japoneses. Essas declarações também foram elaboradas no tópico de discussão - palavras engraçadas da batyan.

Os enunciados aproximam-se do que Schlieben-Lange (1993) chama de discurso público sobre a língua, que são formas a partir das quais os falantes avaliam o desempenho da fala e dos próprios falantes. Como argumentado no final do item anterior, considerarei as representações associadas aos imigrantes como simétricas às associadas à identidade lingüística, uma vez que tais declarações foram realizadas dentro de enunciados que continham também a apresentação da língua falada pelos imigrantes.

$\mathrm{Na}$ tabela que se segue, apresento as principais representações depreendidas a partir dos julgamentos qualitativos da identidade lingüística dos imigrantes de japoneses emitidos nos enunciados produzidos no tópico de discussão palavras engraçadas da batyan.

\begin{tabular}{|c|c|c|}
\hline & Representação & Julgamento \\
\hline \multirow[t]{2}{*}{01} & \multirow[t]{2}{*}{$\begin{array}{l}\text { Objeto afetivo: Os enunciados agrupados nessa } \\
\text { categoria buscam atribuir valores à identidade } \\
\text { lingüística por meio dos predicados atribuídos aos } \\
\text { imigrantes. A identidade lingüística aparece } \\
\text { relacionada com a expressão dessa relação afetiva } \\
\text { e não com a expressão comunicacional } \\
\text { propriamente dita. }\end{array}$} & $\begin{array}{l}\text { Humm... aaaah minha batyan } \\
\text { eh taum kawaii }\{\text { bonitaa }\} *_{-} * \\
\text { mas eh tão brava xD } \\
\text { auhauahuahuaha } \\
\text { ela tem costume d fala }\end{array}$ \\
\hline & & $\begin{array}{l}\text { Ai saudades, de tar perto dela } \\
\text { pra presenciar essas perolas. } \\
\text { rss } \\
\text { As batians são d+ heheh }\end{array}$ \\
\hline 02 & $\begin{array}{l}\text { Dissolução de Identidades: Os enunciados que } \\
\text { compõem esta categoria buscam salientar a não } \\
\text { unidade da identidade lingüística do imigrante por } \\
\text { meio do estabelecimento das identidades } \\
\text { lingüísticas da língua portuguesa e da língua } \\
\text { japonesa. Ao realizar esse modo de distinção, a } \\
\text { identidade lingüística atribuída ao imigrante torna- } \\
\text { se responsável pela dissolução das outras } \\
\text { identidades tidas como estáveis. }\end{array}$ & $\begin{array}{l}\text { Mix...A minha misturava } \\
\text { nihongo com o português e } \\
\text { ficava mais ou menos assim: } \\
\text { Mo- chega = Já chega Mesa- } \\
\text { kake = toalha de mesa } \\
\text { E pior é que isso pegou e } \\
\text { agora a família inteira fala } \\
\text { assim! }\end{array}$ \\
\hline
\end{tabular}




\begin{tabular}{|l|l|l|}
\hline $\mathbf{0 3}$ & $\begin{array}{l}\text { Impossibilidade de Expressão: Os enunciados } \\
\text { elencados nessa categoria associam os índices } \\
\text { lingüísticos que permitem a identificação do } \\
\text { batyanês como fator que não permite a expressão } \\
\text { tida como ideal. Trata-se de uma identidade }\end{array}$ & $\begin{array}{l}\text { tanto q tem mtas palavras q } \\
\text { sotaques bem puxados... }\end{array}$ \\
$\begin{array}{l}\text { lingüística vista como falha em relação à à } \\
\text { identidade lingüística na qual a comunicação } \\
\text { supostamente aconteceria sem entraves. }\end{array}$ & e demora ateh a gente explicar \\
hahahah \\
\hline
\end{tabular}

Tabela 4

De modo geral, é possível depreender que as representações construídas em torno da identidade lingüística do imigrante japonês acabam por considerar essa identidade como não legítima para a comunicação. Essa identidade é construída em contraposição com as duas identidades lingüísticas consideradas legítimas, a da língua portuguesa e da língua japonesa. No entanto, ela não é vista como uma nova identidade, mas como resultado da diluição das outras duas. O valor atribuído, então, deixa de relacionar-se com a comunicação estabelecida por essa língua e passa a ter um valor meramente afetivo.

Se, por um lado, os membros da comunidade buscam ressaltar o valor afetivo relacionado diretamente com a figura da avó, por outro, procura-se afastar dessa identidade lingüística vista como inadequada para a expressão. Nessa direção, o riso, ao mesmo tempo em que aponta para a cumplicidade da relação afetiva com a avó, também indicia a adesão a uma outra identidade lingüística a partir da qual é possível identificar as não-coincidências apresentadas pelo batyanês.

Nos enunciados produzidos no tópico palavras engraçadas da batyan, a avaliação da produção lingüística dos imigrantes é realizada com relação à identidade da língua portuguesa. No entanto, por meio das entrevistas, é possível observar que, em relação à identidade da língua japonesa, a linguagem utilizada pelos imigrantes também será considerada inadequada, como pode ser depreendido do trecho abaixo:

1 Entrevistador: e com a língua japonesa como era seu contato?

2 Informante 2: foi mais na escola do que em casa... eu estou tentando fazer um

3 curso on-line de japonês ( ) inclusive é um site bacaninha até te mostro mas ta

4 meio difícil também porque aí a facu(ldade) trabalho não sei o que(...) fui dormir quatro 
5 horas da manhã estes dias não consigo fazer também muito esse negócio mas

6 com o pai assim por exemplo não tem muito como aprender porque ele já

7 esqueceu muita coisa tipo lê é uma coisa assim que ele já não faz mais mesmo

8 porque nunca mais viu assim algo escrito em japonês no máximo ele ouvia e

9 falava assim por isso que é mais na escola mesmo

10 Entrevistador: e na casa da sua vó...

11 Informante 2: é: na casa da minha avó eu converso muito pouco em japonês com a

12 minha tia e minha avó no máximo escuto a conversa das duas e do meu pai com

13 minha vó isso é o máximo porque mesmo meu pai e minha tia eles não

14 falam em japonês eles falam em batyanês misturam tudo e o japonês que eles

15 falam é antigo sabe não é o japonês que a gente aprende no nihongakôu

Ao ser interrogado a respeito do seu contato com a língua japonesa, o informante distingue dois espaços: o familiar e o escolar (linha 2). A distinção entre esses dois espaços é realizada por meio da comparação que atribui à escola um peso maior do que ao ambiente familiar.

Após realizar essa separação, inicia-se uma digressão (linha 2-5) em que narra sua tentativa de aprender a língua por meio de um site, uma ferramenta pedagógica exterior à família. O retorno à comparação entre os espaços é feito ainda na linha 5 pelo conectivo mas, utilizado para contrapor a possibilidade de aprendizagem por meio da escola e do site com a da família.

Percebe-se que o informante relaciona a expressão "contato com a língua japonesa" com a aprendizagem, em especial, com a escrita utilizada como argumento a favor da tese de que o seu "contato" com a língua japonesa teria sido maior na escola do que com a família.

Essa linha de interpretação ganha força com a resposta à intervenção do entrevistador (linha 10) que possibilita explicitar as representações da identidade lingüística dos imigrantes em contraposição à identidade da língua japonesa. A remissão ao batyanês como identidade lingüística da fala familiar aparece novamente associada a uma não unidade e também a uma inadequação ao tempo (o japonês que eles falam é antigo, linhas 14-15).

Entre as linhas 11 e 15, observam-se quatro ocorrências da palavra "japonês" para referir-se à língua japonesa. A primeira ocorrência aparece associada com a prática lingüística do próprio informante assinalada pelo verbo conversar em primeira pessoa 
(linha 11). Essa prática, que aparece quantificada pela expressão muito pouco, acaba sendo anulada pela introdução do verbo escutar (linha 12) que aparece associado à expressão no máximo (linha 12).

Na seqüência, o próprio emprego de japonês para referir-se à prática lingüística, agora somente observada, é considerada inadequada (eles não falam em japonês - linha 14) e para isso o informante, que também é membro da comunidade virtual $E$ u falo Batyanês, utiliza-se da palavra batyanês para nomear a identidade lingüística familiar. Dessa forma, a segunda ocorrência da palavra japonês na linha 14 (o japonês que eles falam) é empregada para marcar a diferença entre a identidade lingüística associada ao imigrante e a considerada como legítima da língua japonesa.

É a partir da adesão a uma identidade lingüística considerada como legítima que os membros da comunidade atribuem representações disfóricas à identidade lingüística dos imigrantes japoneses, vista como uma língua inadequada para a comunicação uma vez que é possível identificar vários níveis de não-coincidências.

As marcas lingüísticas dos diferentes níveis (fonético, fonológico, morfossintático, pragmático e textual) funcionam como exemplos da inadequação da identidade lingüística atribuída aos imigrantes. É uma linguagem cujo efeito fica reduzido ao riso ou ao vínculo afetivo estabelecido por meio da figura da avó. Pode-se considerar, portanto, que a representação desta identidade lingüística como objeto afetivo torna-se uma estratégia de assimilação de uma identidade lingüística tida como legítima para a expressão.

Trata-se de um movimento por meio do qual os membros da comunidade colocam-se na posição de identificar e supostamente acolher essa identidade lingüística. No entanto, os próprios membros utilizam dessa posição para considerar como inadequada em relação às identidades tidas como legítimas.

No capítulo que se segue, deter-me-ei nos enunciados produzidos por descendentes de imigrantes japoneses que possuem como característica a articulação de vários enunciadores (DUCROT, 1984) por um locutor que desqualifica as representações associadas às identidades étnica e lingüística dos imigrantes japoneses. O objetivo é analisar as implicações que as representações dessas identidades têm sobre a produção lingüística dos descendentes. 


\section{REPRESENTAÇÕES E PRODUÇÃO LINGÜÍSTICA: UM ESTUDO DAS CONDICIONANTES DISCURSIVAS NO PROCESSO DE UNIFORMIZAÇÃO DA LINGUAGEM}

Este capítulo tem como objetivo a análise dos efeitos de sentido produzidos pela circulação das representações associadas aos japoneses nas produções dos enunciados do corpus desta dissertação. Apresentarei a análise de enunciados que possuem como traço comum manifestação de marcas lingüísticas que permitem identificar o movimento estabelecido entre as representações e a produção do enunciado. Trata-se da análise dos enunciados nos quais o locutor explicita algumas das representações associadas à identidade étnica japonesa para poder construir sua declaração.

Nos capítulos anteriores foram descritos os modos pelos quais são construídas as declarações acerca das identidades étnica (capítulo 1) e lingüística (capítulo 2), e, também, analisadas as representações associadas a essas identidades. A partir das análises realizadas nesses capítulos, podem-se depreender algumas implicações entre as representações associadas às identidades e a produção dos próprios enunciados, como, por exemplo, o predomínio da mediação pela imagem na tentativa de neutralizar as representações consideradas disfóricas em relação à identidade étnica japonesa.

Em relação às representações atribuídas à identidade lingüística dos imigrantes japoneses, pode-se depreender que esta é marcada como um desvio das identidades consideradas ideais de língua portuguesa e de língua japonesa. Esse desvio é pontuado pela necessidade de nomear (batyanês) uma outra identidade para dar conta dos fenômenos que caracterizam a fala dos imigrantes japoneses.

Essa identidade lingüística - batyanês - é tomada como motivo para ocorrência dos desvios em relação ao considerado ideal nos diversos níveis lingüísticos (como analisados no capítulo anterior). Procuram-se atribuir valores afetivos, restringindo essa identidade ao ambiente familiar, uma vez que as finalidades comunicativas da fala dos imigrantes não são consideradas legítimas. 
A atribuição de valores como a inadequação da comunicação, desvio das identidades lingüísticas consideradas ideais, língua afetiva e língua familiar podem atuar como condicionantes discursivas para o processo de uniformização da linguagem em duas frentes:

a- reforço das identidades lingüísticas consideradas ideais, funcionando como um argumento a favor da adesão das formas linguiísticas consideradas prestigiadas; e

b- apagamento da utilização dos recursos lingüísticos que possam remeter a identidade lingüística do batyanês como forma de se afastar das representações consideradas disfóricas.

Para evidenciar essas duas frentes que atuam no processo de uniformização da linguagem é necessário considerar os efeitos causados pelas representações atribuídas às identidades associadas aos japoneses na produção dos enunciados. Realizar tal análise implica em considerar que a construção do enunciado é feita a partir da relação com outros enunciados e que o próprio enunciado não pode ser compreendido como resultado de um único dizer, ou seja, elaborado por um único enunciador.

Selecionei dois enunciados nos quais é possível observar marcas lingüísticas que apontam para a articulação de mais de um enunciador. Essa articulação permite que algumas das representações associadas à identidade étnica dos japoneses sejam apresentadas por um enunciador enquanto que outros enunciadores podem realizar julgamentos sobre essas representações, possibilitando inferir quais sentidos o locutor desses enunciados pretende atingir.

Um dos enunciados foi retirado do conjunto das 204 (duzentas e quatro) produções realizadas no tópico de discussão intitulado palavras engraçadas da batyan, tópico apresentado e analisado no capítulo anterior. O outro é um trecho da entrevista realizada com a informante-1. A reunião desses enunciados para compor essa análise foi feita levando em conta as características de sua construção em detrimento de seu conteúdo temático. $\mathrm{O}$ enunciado produzido no site de relacionamento tem como tema a fala da avó buscando caracterizar e atribuir valores a essa fala, enquanto o trecho da entrevista versa sobre o ponto de vista da avó sobre os relacionamentos amorosos dos netos. 
Optei por utilizar como ferramenta para análise desses enunciados a Teoria Polifônica da Enunciação, elaborada por Ducrot (1984), cujo principal objetivo é se contrapor ao "pressuposto da unidade do sujeito falante" (op. cit.: 161). A opção de buscar referência nos trabalhos de Ducrot também relaciona-se com o desenvolvimento de sua teoria semântica que inclui a argumentação como constitutiva da linguagem. Em suas palavras: "a utilização argumentativa da língua, longe de lhe ser sobreposta, está nela inscrita, é prevista em sua organização interna" (DUCROT, 1973: 180).

\subsection{A COMPOSIÇÃO DOS ENUNCIADOS E A DIREÇÃO DA SIGNIFICAÇÃO}

A utilização de mais de um enunciador permite que o locutor se utilize de argumentos contraditórios para a construção do enunciado sem que destrua sua significação. Por meio dessa operação, é possível distinguir os diferentes valores dados a cada argumento e também a direção na interpretação que o locutor espera de seu interlocutor.

Em seu texto As escalas Argumentativas, Ducrot (op. cit.) dedica-se ao estudo dos operadores argumentativos que estabelecem uma relação de forças entre as proposições que compõem um enunciado. Esses elementos (morfemas, expressões ou termos), dos quais o autor destaca os advérbios, adjetivos, a negação e a implicação, fazem com que um argumento possa ganhar ou perder força dentro do enunciado. Para Ducrot, essas marcas devem ser tomadas como indícios de que os enunciados podem desempenhar a função argumentativa em que o locutor orienta o destinatário na direção da conclusão que pretende estabelecer, criando pesos diferentes para os argumentos que constituem o enunciado.

A existência de escalas argumentativas seria uma primeira prova da não unicidade do enunciado, uma vez que cria uma comparação entre dois argumentos, apontando para a manifestação de mais de uma voz em um enunciado isolado. Por exemplo, ao considerar a frase pior que é verdade, pode-se dizer que a expressão adverbial pior que cria uma escala argumentativa que atribui um valor para o argumento direcionando a interpretação que o interlocutor deve fazer.

Da possibilidade de descrição das escalas argumentativas (op. cit.), o autor passa a considerar a formação do enunciado como a articulação de vários enunciadores, distinguindo assim a pessoa no mundo, o locutor e os enunciadores (DUCROT, 1984). 
O locutor fala no sentido em que o narrador relata, ou seja, ele é dado como a fonte de um discurso. Mas, as atitudes expressas neste discurso podem ser atribuídas a enunciadores de que se distancia - como os pontos de vista manifestados na narrativa podem ser sujeitos de consciência estranhos ao narrador (op. cit.: 196)

Essa distinção leva o autor a separar a figura da pessoa que realiza a enunciação (o ser no mundo), da instância lingüística que organização o discurso (o locutor) e as vozes que se manifestam em meio ao discurso do locutor (os enunciadores).

Os dois trabalhos citados de Ducrot constituem instrumentos importantes para a análise dos enunciados selecionados para este capítulo porque permitem analisar suas composições e compreender as relações estabelecidas no próprio interior do enunciado, que não fica reduzido ao seu conteúdo informacional, mas, também, é compreendido como um elemento argumentativo que visa a dirigir a significação. Para Ducrot (1973) "o conteúdo informacional do enunciado (suas condições de verdade) depende de considerações relativas a seu valor argumentativo" (op. cit.: 206).

Nos enunciados selecionados, esse instrumental permitirá distinguir os diferentes enunciadores articulados pelo locutor para construir uma direção argumentativa. Portanto, é a direção argumentativa que pode indiciar um processo de uniformização da linguagem, uma vez que, por meio do seu estabelecimento, o locutor realiza uma ação sobre seu interlocutor. Assim sendo, a hipótese que defendo é a de que o estabelecimento de uma direção argumentativa que atribui valores eufóricos ou disfóricos pode funcionar como condicionantes discursivas que atuam na produção lingüística dos falantes.

Iniciarei a análise pelo enunciado recortado da comunidade virtual cujo tema é fala dos imigrantes japoneses e, na sequiência, a análise de um trecho da entrevista com a informante 1 , que trata do ponto de vista da avó sobre os relacionamentos amorosos da família.

\subsection{ENTRE A DECLARAÇÃo DE ACOLHIMENTO E A ATITUDE DE REJEIÇÃO}

O primeiro enunciado faz parte do conjunto apresentado no capítulo dois desta dissertação. Foi produzido no tópico de discussão intitulado palavras engraçadas da Batyan dentro da comunidade virtual Eu falo Batyanês. Transcrevo abaixo o recorte: 


\section{Uhuhuhuh}

2 Que engraçaaaadoooo... hahaha pior q elas são tão fofas, que eu não tenhu

3 Coragem de ri... minha vó fala "chá de horterão"... "Baleloche”... "enberope”...

4 “regume”... “bombelo”... "faxinela”... e escreveu uma vez na agenda... o telefone

5 do “o torrino"... huhuahuahuaha tadinhaaaa :P

Esse enunciado possui as duas características que foram analisadas no capítulo anterior: a) a confecção de exemplos que caracterizariam essa identidade lingüística e, b) a realização de julgamentos sobre a identidade lingüística associada aos imigrantes japoneses.

Como exemplos da fala da identidade lingüística atribuída à avó, encontram-se a troca da lateral [1] pela vibrante [r] (horterão, enberope, regume, linha 2) e o contrário (Baleloche, bombelo, faxinela), a troca da labiodental-fricativa [v] pela bilabial-plosiva [b] e, ainda, o registro de um exemplo que é domínio da língua escrita (o torrino, linha $4)$.

O julgamento mais evidente é o riso (linha 1, 2 e 5), também marcado pelo adjetivo engraçado (linha 2). No entanto, como em outros enunciados, é possível observar uma simetria entre os valores atribuídos à língua e também ao falante, uma vez que se pode rir da língua ou do falante. Essa linha de interpretação também pode ser sustentada pelo emprego do adjetivo fofas na linha 2 para qualificar elas (referindo a avós). Trata-se de uma identidade lingüística que é sustentada na relação afetiva estabelecida com a figura da avó, porém, tanto a falante quanto sua identidade lingüística não se encontram em posição de estabelecer um contato comunicativo dentro das identidades lingüísticas consideradas ideais.

A análise dessas duas características não foge àquelas já realizadas no capítulo anterior. No entanto, interessa-me observar, nesse momento, a relação estabelecida entre os diferentes enunciadores que o locutor do enunciado utiliza-se para ordenar o discurso. Podem-se distinguir, pelo menos, três enunciadores:

1) o enunciador responsável pelo riso (linhas 1 uhuhuhuh, linha 2 Que engraçaaaadoooo...hahaha, linha 5 huhuahuahuaha $: P$ )

2) o enunciador responsável por salvaguardar a figura da avó (linha 2 pior q elas são tão fofas que eu não tenhu coragem de ri e linha 5 tadinhaaaa) 
3) o enunciador responsável por confeccionar os exemplos (linha 3 minha vó fala, "chá de horterão"... "Baleloche”... “enberope”... "regume”..., linha 4 "bombelo"... “faxinela”, e escreveu uma vez na agenda...o telefone do "o torrino”...

Essa divisão em três enunciadores foi realizada tendo em vista a função exercida por cada um deles na construção do enunciado. O enunciador 1, responsável pelo riso, é também o que realiza a interpretação da identidade lingüística atribuída aos imigrantes japoneses. Os exemplos utilizados para moldar essa identidade, apresentados pelo enunciador 3, têm como principal efeito o riso, ou seja, torna-se uma maneira de marcar que a língua utilizada pelos imigrantes japoneses não cumpre sua função comunicativa.

Essa interpretação pode ser sustentada também ao considerar o argumento utilizado pelo enunciador 2 na tentativa de salvaguardar a imagem da avó das representações disfóricas associadas ao riso. A estratégia utilizada por esse enunciador consiste em fazer apelo emocional (fofas linha 2 e tadinhaaaa linha 5) criando uma justificativa para o que é marcado como desvio das identidades consideradas ideais.

É importante observar que o acolhimento dessa identidade lingüística é feito por meio da exclusão do falante do jogo comunicativo, ou seja, questiona-se a legitimidade da participação da avó na comunicação de modo a atribuir-lhe predicados muito próximos aos utilizados comumente para qualificar a fala de crianças em fase de aquisição de linguagem.

Dessa forma, ao buscar responder às representações disfóricas, a identidade linguiística atribuída ao imigrante é considerada ilegítima para atingir os fins comunicativos, sendo responsável por causar o efeito de riso e só se justifica por ocupar um lugar meramente afetivo.

Entre o enunciador 1 e o enunciador 2 estabelece-se um conflito, uma vez que o primeiro busca causar o efeito de riso enquanto o segundo declara não poder realizar tal prática. $\mathrm{O}$ enunciador 2 é introduzido na segunda linha por uma expressão adverbial (pior que linha 2) que cumpre duas funções: a) atribuir valor disfórico ao adjetivo engraçado, criando uma incompatibilidade entre as proposições ser fofa e ser engraçada, $e$ b) criar uma escala argumentativa em que a força da proposição ser engraçada é diminuída.

A expressão adverbial pior que (linha 2) diminui a força argumentativa da proposição ser engraçado porque introduz uma nova proposição que se coloca 
incompatível com a primeira, uma vez que o enunciador considera uma conseqüência de ser fofa (linha 2) o fato de não ter coragem de rir (linhas 2-3).

Ao considerar os trechos a partir dos quais se depreendeu o enunciador 2, podese estabelecer uma articulação de outros sub-enunciadores utilizados para construir a salvaguarda da imagem da avó: a) o que apresenta a proposição ser fofa e b) o que apresenta a conseqüência de considerar essa proposição que, por sua vez, é construída por meio de uma negação.

Para Ducrot (1973), a negação também exige pelo menos dois enunciadores, um que afirma o ponto de vista e o outro responsável por negar a afirmação. No caso do enunciado em questão, essa forma de análise obriga a considerar a formação de uma nova escala argumentativa que novamente diminui a força argumentativa da proposição ser engraçada, desta vez, pela negação da proposição ter coragem de rir. Se por um lado a negação irá diminuir a força da proposição ser engraçado, por outro, atua como um reforço pois também contém a afirmação (ter coragem de rir).

Nos períodos analisados (linhas 1-3), pode-se, então, inferir o seguinte movimento realizado pelo locutor para a construção da escala argumentativa:

1) afirmação da proposição sobre a identidade lingüística atribuída aos imigrantes japoneses: ser engraçada;

2) diminuição da força argumentativa da primeira proposição pela criação de uma proposição incompatível com a primeira: ser fofa;

3) reforço da proposição expressa em um pela enunciação de uma proposição similar: ter coragem de rir; $e$

4) diminuição da força argumentativa pela negação da proposição expressa em três.

Após essa construção, o locutor mobiliza um terceiro enunciador responsável por apresentar a língua utilizada pela representante do grupo étnico. O enunciador 3 também pode ser subdividido em dois: a) assume a posição de observador marcada pela utilização da terceira pessoa (minha vó fala, linha 3) e b) realiza a confecção dos exemplos supostamente da maneira como foram produzidos pela avó, o que é marcado pela utilização de aspas nos itens lexicais entre as linhas 3 e 4. Dessa forma, depois da tentativa de salvaguardar a figura da avó, busca-se construir a impressão de realidade e neutralidade. 
É a partir da confecção dos exemplos que os enunciadores 1 e 2 (linha 5) são novamente utilizados para finalizar a construção do enunciado. $\mathrm{O}$ enunciador 1 retorna logo após a apresentação dos exemplos marcando que a inserção de dois operadores para diminuir a força argumentativa da proposição ser engraçado não foi suficiente para conter seu enunciador. Na seqüência, tem-se mais uma vez a voz do enunciador 2 , no entanto, sem realizar nenhuma tentativa de diminuir a força argumentativa, sendo empregado somente para atenuar as possíveis representações disfóricas que podem ser atribuídas à identidade lingüística e étnica da avó.

Trata-se de um enunciado no qual é possível identificar um locutor que articula pelo menos três vozes: a) uma que busca ridicularizar a identidade lingüística atribuída aos imigrantes japoneses; b) diante da possibilidade de ser interpretada como preconceituosa, uma voz que justifica a utilização dessa língua por parte dos imigrantes e c) uma que se quer neutra.

O locutor utiliza-se dessas três vozes para construir a direção argumentativa que visa a desqualificar a identidade lingüística associada ao imigrante japonês. $\mathrm{O}$ fato de haver uma simetria entre a identidade lingüística e a identidade da pessoa faz com que seja preciso inserir o enunciador 2 para que possa salvaguardar a imagem da avó, no entanto, os argumentos utilizados para realizar essa operação atribuem a ela um lugar considerado não legítimo para o exercício da comunicação.

Ao mesmo tempo em que é necessário inserir declarações que busquem justificar os motivos pelos quais não se deve ridicularizar a fala da imigrante, também é preciso afastar-se dessa identidade para poder garantir a não associação às representações disfóricas ligadas às identidades étnicas e lingüísticas e, principalmente, para se aproximar das identidades lingüísticas consideradas idéias, aquelas em que a comunicação se efetua.

Essa direção argumentativa funciona como o que estou chamando, nesse trabalho, de condicionante discursiva, pois, uma vez aceita como a maneira correta de interpretar, pode funcionar como força para que determinados recursos lingüísticos sejam, ou não, empregados. No que se segue, apresento uma análise em que é possível depreender a relação estabelecida entre o emprego de itens lexicais e as representações associadas às identidades lingüísticas atribuídas a esses itens. 


\subsection{REPRESENTAÇÕES E PRODUÇÃO LINGÜÍSTICA}

O recorte que será apresentado nesta seção é um trecho da entrevista realizada com a informante 1 , no qual é possível observar o que a sociolingüística variacionista nomeia de variantes, no caso, um mesmo referente que é realizado por itens lexicais diferentes.

Observa-se, nesse recorte, a utilização de alguns itens lexicais marcados como representantes da identidade da língua japonesa (batyan, gaijin [estrangeiro, termo marcado negativamente], nihonjin [japonês - termo marcado positivamente]) de forma semelhante ao enunciado da descrição da comunidade do Orkut, analisada no capítulo dois.

É importante lembrar que não se trata de verificar os processos de incorporação de itens lexicais marcados como representantes da identidade língua japonesa, nem de determinar qual é a proveniência de determinada palavra. A própria noção de variantes não é aplicável a um trabalho que se apóie no referencial teórico da análise do discurso, uma vez que essa postula a não identidade palavra com ela mesma.

Meu interesse recai sobre a utilização desses termos dentro da seqüência argumentativa na qual estão inseridos. Trata-se de uma análise que privilegia a implicação das representações associadas a uma ou outra identidade lingüística na produção do enunciado. Transcrevo o recorte:

1 Inf-1: na minha família tem vários mestiços na família do meu namorado não

2 Doc: e como as batyans encaram isto?

3 Inf-1: a primeira coisa que minha batyan pergunta quando começa namorar: "é

4 gaijin? É gaijin ou nihonjin"?

5 Doc: pode ser curiosidade?

6 Inf-1: ah não... ela fala gaijin não presta... é estranho ela falar isto porque ela tem

7 filhos casados com não descendentes.

Como já foi mencionado na Introdução desta dissertação, as entrevistas tinham como pauta alguns pontos temáticos, como história da família, contato com a língua japonesa etc., no entanto, não foi estabelecido previamente nenhum roteiro de perguntas. Além desse manejo, o entrevistador não se manteve neutro e realizou intervenções pontuais nos momentos em que julgou importante esclarecer ou ampliar o texto sobre determinado tópico. 
Este movimento permitiu-me interromper a resposta da informante, buscando uma relação com as representações que estão ligadas à avó, por ser a representante da língua japonesa na família. Nessa direção, torna-se significativo a alteração que existe entre o primeiro enunciado (linhas 3 e 4) e o que segue à minha intervenção (linhas 7 e 8): no primeiro observa-se a utilização da palavra mestiço (linha 1) que será desdobrada no segundo enunciado em gaijin ou nihonjin (linhas 3 e 4).

A atualização da palavra gaijin, que é empregada para marcar a exceção, aqueles que não são japoneses, além de designar esse referente, também atualiza as representações de preconceito para com aqueles que não são descendentes de japoneses por parte dos imigrantes. É a leitura privilegiada após a segunda intervenção que busca dar à palavra gaijin um lugar de neutralidade (pode ser curiosidade, linha 5) - e é respondida negativamente (Ah não, linha 6).

A construção que se segue traz um novo item lexical para designar o referente gaijin que apareceu no enunciado anterior, a saber: não-descendente. Os dois itens lexicais possuem o mesmo referente, no entanto, os sentidos não são os mesmos, pois as representações são alteradas, de modo que gaijin (linha 3 e 4) e não-descendente (linha 7) cumprem funções diferentes. Enquanto o primeiro é atribuído diretamente ao modo como a avó nomeia esse referente, acionando as representações de preconceito, o segundo é empregado por um enunciador que toma distância, marcada pela utilização da terceira pessoa para designar a avó, afastando-se, assim, da posição de preconceito.

É interessante observar que a utilização do item lexical representante da identidade lingüística japonesa aparece duas vezes em períodos cujos verbos descrevem uma ação da avó que pergunta, fala, enquanto a utilização de não-descendentes aparece dentro de um argumento factual.

O emprego do item lexical associado à identidade lingüística japonesa marca ao mesmo tempo o referente e as representações atribuídas a esse referente por parte dos imigrantes japoneses. Ao deparar-se com o efeito de sentido produzido por esse item que marca uma posição preconceituosa, o locutor insere um enunciador que pode se afastar dessa posição e, por isso, emprega um outro item lexical que serve para buscar uma posição neutra.

Desse modo, pode-se afirmar que as formações imaginárias acionadas pelas representações atribuídas aos itens lexicais funcionam como condicionante para o emprego de um ou de outro de acordo com a direção argumentativa que o locutor pretende construir. 
O emprego de gaijin e não-descendente, como analisado acima, já aponta para a construção de uma direção argumentativa que atribui à avó o lugar de preconceito. Para explicitar a construção dessa direção, torna-se importante a análise do enunciado produzido a partir da intervenção do entrevistador (Ah! Não: ... ela fala gaijin não presta... é estranho ela falar isso porque ela tem filhos casados com não descendentes, linhas 6 e 7) por possibilitar uma análise da articulação realizada pelo locutor de dois enunciadores.

Podem-se depreender dois enunciadores diferentes de acordo com a função exercida na construção do enunciado: a) é responsável por responder ao questionamento do significado do termo gaijin e b) o segundo questiona o ponto de vista da avó por meio da apresentação de fatos. Ainda é preciso considerar dois tempos na construção argumentativa de cada um dos dois enunciadores:

a) Enunciador 1: negociação do sentido de gaijin

O enunciador 1 é responsável pela determinação do sentido de gaijin, questionado pelo entrevistador após as linhas 3 e 4 . A intervenção foi realizada pela negativa, pois, ao invés de ser uma pergunta que iria em conformidade com as representações associada ao item, afirmando haver preconceito, a pergunta toma o lugar de curiosidade. Por esse movimento, deixa implícito o valor atribuído ao termo, o que fica indiciado pelo uso da expressão 'pode ser', ou seja, aproveitando do conhecimento da conotação negativa da palavra gaijin, buscou-se instaurar uma dúvida com relação ao sentido expresso pelo item.

Para responder a esta intervenção, o locutor utiliza-se de um enunciador inserido por um marcador conversacional que cumpre a função de tomar o turno e negar a possibilidade do item estar ligado a uma outra representação. A utilização de um marcador conversacional juntamente com advérbio de negação permite que esse enunciador possa continuar sua construção após uma pequena pausa. Como estratégia para sustentar seu posicionamento em relação à intervenção, esse enunciador utiliza-se da voz da avó como argumento para (re)afirmar as representações de preconceito ligadas ao item lexical, uma vez que a imigrante atribui o predicado não presta (linha 6) ao termo gaijin. 
Primeiramente, o enunciador coloca a sua própria voz para responder com uma negação enfática e, em um segundo momento, articula a voz da avó como forma de exemplificar sua resposta.

b-) Enunciador 2: julgamento da posição adotada pela avó

A partir do que foi afirmado pelo enunciador 1, esse realiza uma avaliação da proposição atribuída à avó. $\mathrm{O}$ enunciador 2 também pode ser subdivido em dois outros: a) responsável por denunciar a incongruência do posicionamento atribuído à avó pelo enunciador $1 \mathrm{e}$ b) responsável por apresentar o argumento factual que sustenta a denúncia feita por a.

Entre o enunciador 1 e o 2 há uma pausa que marca a mudança de enunciador, a introdução do enunciador 2 é feita por meio do sintagma É estranho (linha 6), que realiza o julgamento da posição atribuída à avó pelo enunciador um. É importante salientar que a escala argumentativa, mesmo instaurando a desconfiança sobre a proposição contida, não diminui a força argumentativa porque não se posiciona em relação ao enunciador 1 , mas em relação à posição atribuída à avó por esse enunciador.

Nessa direção, pode-se afirmar que a expressão é utilizada como um operador que aumenta a força argumentativa do enunciador 1 , em especial, a tentativa de relatar 0 posicionamento da avó, uma vez que toma sua fala como objeto para realizar o julgamento (É estranho ela falar isso - linha 6). A continuidade, também, pode ser indiciada pela utilização do pronome anafórico isso que retoma a voz da avó enunciada pelo primeiro enunciador.

Para finalizar o enunciado, o segundo enunciador utiliza um argumento factual (porque ela tem filhos casados com não descendentes, linhas 6-7) para sustentar seu julgamento apresentado anteriormente. Assim, o julgamento deixa de ser baseado somente na fala da avó e passa a mostrar a incongruência entre a fala da avó e a realidade.

Enquanto o enunciado retirado da comunidade virtual $E u$ falo batyanês questiona a legitimidade da participação da avó no jogo comunicativo, a fala da entrevistada, que nega a contemporização realizada pela intervenção do entrevistador, faz emergir uma figura da avó preconceituosa e incongruente. O locutor articula dois enunciadores que atribuem falas à avó que visam a demonstrar sua ineficiência comunicativa, além das representações de preconceito. 
Dessa forma, é possível inferir do trecho da entrevista analisado que a escolha por um item lexical que marca a identidade lingüística/ étnica associada ao imigrante japonês está implicada na construção da direção argumentativa que o locutor deseja produzir. Ou seja, as representações associadas aos recursos lingüísticos funcionam como condicionantes discursivas que influenciam a escolha dos itens lexicais a serem empregados de acordo com a posição que o locutor deseja assumir.

Esses enunciados atuam como condicionantes discursivas e fomentam duas atitudes que podem colaborar com o processo de uniformização da linguagem, a saber: o preconceito lingüístico e a intolerância lingüística. Trabalhos como os de Leite (2005) e Bueno (2006) têm apontado para a necessidade de diferenciar essas duas atitudes ao considerar os discursos acerca da linguagem.

Interessa-me, especialmente, o trabalho de Leite (op. cit) no qual a autora estabelece a distinção entre os dois conceitos para proceder a análise de um caso de intolerância lingüística na mídia brasileira. Leite parte da definição dos vocábulos presentes no dicionário e passa a considerar a distinção feita, em especial, na filosofia. Para a autora:

\begin{abstract}
A partir do campo dessa temática filosófica, especificamente em relação à língua, pode se falar tanto de preconceito quanto de intolerância, reconhecendo, contudo, diferenças entre ambos. O preconceito é a discriminação silenciosa e sorrateira que o indivíduo pode ter em relação à linguagem do outro, é um não-gostar, um achar feio ou errado um uso (ou uma língua), sem que se tenha a configuração do que poderia vir a ser o bonito ou correto. A intolerância, ao contrário, é ruidosa, explícita, porque necessariamente, se manifesta por um discurso metalingüístico, calcado em dicotomias, em contrários, como, por exemplo, tradição $x$ modernidade, conhecimento x ignorância, saber x não-saber, e outras congêneres (op. cit.: 85-86).
\end{abstract}

Para meu trabalho, interessa a distinção estabelecida acima porque os enunciados que compuseram o corpus desta dissertação utilizaram-se do discurso metalingüístico para circunscrever a identidade lingüística atribuída ao imigrante japonês. Mas, a utilização dessa modalidade de enunciação tinha como objetivo principal provocar o riso, ou seja, a atitude de discriminação diante da linguagem do outro se inscreve prioritariamente como forma de preconceito lingüístico em relação a uma linguagem considerada engraçada.

No entanto, ao considerar os processos de constituição dos enunciados e, em especial, as condicionantes discursivas depreendidas dos enunciados analisados neste capítulo, é possível traçar um paralelo com a atitude de intolerância lingüística. Trata-se 
de um funcionamento no qual é preciso se afastar da identidade lingüística considerada disfórica para aderir a uma identidade considerada ideal.

O emprego dos itens lexicais associados à identidade lingüística dos imigrantes japoneses analisados atribui a esses recursos lingüísticos representações consideradas disfóricas. Além disso, o enunciador procura aderir um posicionamento que marque a distância com essas representações utilizando-se, assim, de novos recursos para estabelecer a diferença. Trata-se do processo ao qual me refiro ao falar em uniformização da linguagem.

Assim, os recursos lingüísticos deixam de ser utilizados para cumprirem a função comunicativa e passam a ser empregados para marcar uma adesão a uma identidade considerada ideal. 


\section{CONSIDERAÇÕES FINAIS}

Nesta dissertação, busquei dar continuidade às pesquisas que investigam as implicações que a adesão a uma determinada discursividade pode ter sobre a produção lingüística. Escolhi como objeto de estudo enunciados que foram produzidos em diferentes condições de produção, mas que buscam delinear a identidade étnica e lingüística associadas aos imigrantes japoneses e seus descendentes.

Foram duas as questões que nortearam a escrita desta dissertação:

a- Quais operações discursivas são utilizadas pelos sujeitos ao realizarem afirmações sobre a identidade étnica e lingüística de um grupo específico?

b- Quais são as implicações dessas operações discursivas sobre a produção dos enunciados?

A primeira pergunta foi respondida nos capítulos um e dois, os quais se dedicaram à análise dos modos de construção das declarações sobre a identidade étnica e lingüística atribuídas ao imigrante japonês e seus descendentes. A análise buscou depreender as representações associadas a essas identidades e os efeitos de sentido provocados por essas representações nos enunciados em questão.

Já a segunda questão foi abordada no capítulo três, que se dedicou à análise de dois enunciados que permitiram depreender os efeitos de sentido produzidos por condicionantes discursivas na construção dos enunciados. A análise privilegiou a ação exercida pelo locutor ao articular enunciadores diferentes para a construção de uma direção argumentativa.

O capítulo um foi dedicado exclusivamente aos enunciados que realizaram declarações sobre a identidade étnica. Foram analisados enunciados veiculados pela mídia e por representantes de entidades culturais nipo-brasileiras para depreender algumas representações associadas à identidade étnica do "japonês". 
Pôde-se depreender dos enunciados veiculados pela mídia e pelos representantes de entidades culturais nipo-brasileiras a construção de um imaginário que combina a mediação pelos significantes e pela imagem. Essa construção faz com que a identidade seja estabelecida entre significante e objeto, sustentando uma ambivalência entre o sentido eufórico do significante e as representações disfóricas do objeto.

Ainda no capítulo um, apresentei a análise de enunciados produzidos por descendentes de imigrantes japoneses nos quais esses sujeitos declaravam suas próprias identidades étnicas. Por meio da análise dos enunciados produzidos por descendentes de imigrantes japoneses, foi possível depreender uma construção da identidade pautada, predominantemente, pela imagem. Busca-se aderir aos significantes considerados eufóricos e inserir enunciados que possam modificar as representações disfóricas associadas a esses significantes.

A descrição dos modos de construção dos enunciados permitiu concluir que, de maneira geral, essas declarações tornam-se um espaço de disputa em que se busca majoritariamente responder às representações disfóricas associadas a essa identidade étnica, ao invés de procurar realizar uma afirmação da própria identidade.

No capítulo dois, dediquei-me à análise dos enunciados em que os descendentes de imigrantes japoneses buscavam delimitar a identidade lingüística associada aos seus antepassados. A partir da análise, foi possível depreender o estabelecimento de uma identidade lingüística considerada como legítima, a partir da qual os descendentes atribuem representações disfóricas à identidade lingüística dos imigrantes japoneses, vista como uma língua inadequada para a comunicação porque é possível identificar vários níveis de não-coincidências.

As marcas lingüísticas dos diferentes níveis (fonético, fonológico, morfossintático, pragmático e textual) funcionam como exemplos da inadequação da identidade lingüística atribuída aos imigrantes. É uma linguagem cujo efeito fica reduzido ao riso ou ao vínculo afetivo estabelecido por meio da figura da avó. Pode-se considerar, portanto, que a representação desta identidade lingüística como objeto afetivo torna-se uma estratégia de assimilação de uma identidade lingüística tida como legítima para a expressão.

Trata-se de um movimento por meio do qual os locutores assumem a posição de identificar e supostamente acolher essa identidade lingüística. No entanto, os próprios membros utilizam dessa posição para considerar como inadequada em relação às identidades tidas como legítimas. 
Ao considerar as análises realizadas nesses dois capítulos, pode-se afirmar que as construções sobre as identidades étnicas e lingüísticas buscam criar uma representação em função de um ideal no qual não é permitida a presença de nenhum traço disfórico. Por meio da inserção de outros enunciados, os locutores negociam com esse ideal uma representação que possa estar desvinculada de possíveis significados negativos.

Esse processo aponta para uma predominância da identificação imaginária sobre a simbólica. Diante de uma representação considerada disfórica, opta-se pela inserção de novos enunciados que estabeleçam a adesão aos traços considerados eufóricos, não sendo permitido a resignificação desses traços dentro do sistema simbólico.

No capítulo três, persegui os efeitos que a necessidade de se afastar das representações consideradas disfóricas provocam na produção lingüística dos enunciados. Ao se adotar essa postura, os enunciadores apropriam-se de recursos lingüísticos que possam funcionar como marcadores de suas próprias identidades. É esse processo que dá origem às condicionantes discursivas.

O funcionamento dessas condicionantes discursivas atua tanto na produção lingüística quanto no processo de uniformização da língua, pois cria identidades consideradas ideais, as quais podem ser assumidas pela adesão às representações e à (re)produção dos recursos lingüísticos que supostamente estariam associados a essa identidade.

A descrição desse funcionamento alerta para a necessidade de investigar os processos envolvidos na construção das declarações de identidade como forma de ofertar um ideal a partir do qual as diferenças devem ser excluídas. 


\section{REFERÊNCIAS BIBLIOGRÁFICAS}

ANJOS, C. I. A Educação Infantil representada: uma análise da revista Nova Escola (2005-2007). São Paulo: Dissertação (Mestrado), Faculdade de Educação, Universidade de São Paulo, 2008.

AUSTIN, J. L. How to do things with Words. Oxford : Oxford University Press, 1962.

AUTHIER-REVUZ, J (1993) As não-coincidências do dizer e sua representação metaenunciativa - estudo lingüístico e discursivo da modalização autonímica. In: Palavras Incertas: as não-coincidências do dizer. Campinas: Editora da UNICAMP, 1998.

AUTHIER-REVUZ, J (1998a) As não-coincidências do dizer. In: Palavras Incertas: as não-coincidências do dizer. Campinas: Editora da UNICAMP, 1998.

AUTHIER-REVUZ, J (1998b) Enunciação e metaenunciação - heterogeneidades enunciativas e problemáticas do sujeito. In: Palavras Incertas: as não-coincidências do dizer. Campinas: Editora da UNICAMP, 1998.

AUTHIER-REVUZ, J. (1984) Heterogeneidade(s) Enunciativa(s) In: Cadernos de Estudos Lingüísticos. Campinas:nº 19 julho/dezembro, 1990. p. 25-42.

BARZOTTO, V.H. \& RIOLFI, C. R. O ensino de língua materna no Brasilconsiderações sobre os paradoxos entre o uno e o múltiplo, 2008 (mimeo).

BARZOTTO, V.H. Leitura de Revistas Periódicas: forma, texto e discurso - Um estudo sobre a revista Realidade (1966-1976). Campinas-SP: Tese (doutorado). IEL/Unicamp 1998. 
BENVENISTE, E. (1958) Da subjetividade na linguagem. In: Problemas de Lingüística Geral I. Campinas:Pontes, 1995.

BENVENISTE, E. (1970) Aparelho formal da enunciação. In : Problemas de Lingüística Geral II. Campinas :Pontes, 1995.

BOURDIEU, P.(1982) Economia das trocas lingüísticas - o que falar quer dizer? São Paulo:Edusp, 1998.

BRAGA; M.L Variáveis discursivas sob a perspectiva da Teoria da Variação In: MOLLICA; M.C. \& BRAGA M.L. Introdução à Sociolinguiística. São Paulo: Contexto, 2003.

BUENO, A. M. Intolerância lingüística e imigração. São Paulo: Dissertação (Mestrado), Faculdade de Filosofia, Letras e Ciências Humanas, Universidade de São Paulo, 2006.

CHAMBERS, J.K. Studying Language Variation: An Informal Epistemology. In: CHAMBERS, J. K, TRUDGILL P. \& SCHILling-ESTES, N. The Handbook of Language Variation and Change. USA: Blackwell Publishing, 2006.

CHARTIER, R. História Cultural- Entre Práticas e Representações. Lisboa: Difel, 1990.

COELHO, R. F. É nóis na fita! Duas variáveis lingüísticas numa vizinhança da periferia paulistana.(O pronome de primeira pessoa do plural e a marcação do plural no verbo). São Paulo: Dissertação (Mestrado), Faculdade de Filosofia, Letras e Ciências Humanas, 2006.

COSERIU; E. Sistema, norma e fala In: Teoria da linguagem e lingüística Geral, Rio de Janeiro: Presença, 1979.

DECROSSE; A. Um mito histórico, a língua Materna In: Vermes; G. e Boutet. Multilingüismo. Campinas: Ed. Da UNICAMP, 1989. 
DEZEM, R. Matizes do "amarelo": a gênese dos discursos sobre os orientais no Brasil (1878-1908). São Paulo: Humanitas, 2005.

DUCROT, O. (1973) As Escalas Argumentativas. In: Provar e Dizer, São Paulo: Global, 1981.

DUCROT, O. (1984) Esboço de uma teoria polifônica da Enunciação. In: O dizer e o dito. Campinas, São Paulo : Pontes, 1987.

EDWARDS, J. Ethnic Identity and Bilingual Education In: GILES, H. Language and Ethnicity and Intergroup Relations London: Academic Press, 1994.

FOUCAULT, M. (1970). A ordem do discurso. São Paulo: Loyola, 1999.

FOUGHT, C. Ethnicity In: CHAMBERS; J. K, TRUDGILL P. \& SCHILLING-ESTES N. The Handbook of Language Variation and Change. USA: Blackwell Publishing, 2006.

FREUD, S. (1895). Estudos sobre a Histeria (Breuer e Freud). Edição Standard Brasileira das Obras Completas de Sigmund Freud, v. II, 1974.

FREUD, S. (1905). Três ensaios sobre a teoria da sexualidade. Edição Standard Brasileira das Obras Completas de Sigmund Freud, v. VII, 1974.

FREUD, S. (1908). Sobre as teorias sexuais das crianças. Edição Standard Brasileira das Obras Completas de Sigmund Freud. v. XI, 1974.

FREUD, S. (1921). Psicologia das massas e análise do eu. Edição Standard Brasileira das Obras Completas de Sigmund Freud.v. XVIII, 1974.

FREUD, S. (1924). A dissolução do complexo de Édipo. Edição Standard Brasileira das Obras Completas de Sigmund Freud. v. XIX,1974. 
GARDENAL, L.M.S. A alternância de código nas falas de nipo-brasileiros de Aliança e Fukuhaku-Mura dos informantes isseis na pesquisa : as línguas faladas nas comunidades nikkei do Brasil. São Paulo: Dissertação de Mestrado, Faculdade de Filosofia, Letras e Ciências Humanas, Universidade de São Paulo, 2008.

IGREJA, S. G. A formação de uma única opinião: a argumentação na mídia impressa a respeito da greve na USP. São Paulo: Relatório de Iniciação Científica, Faculdade de Educação, Universidade de São Paulo, 2008.

KANASHIRO, C.K.J. A interferência da língua japonesa falada por nipobrasileiros : estudo de aspectos da concordância nominal e verbal. São Paulo: Tese (Doutorado), Faculdade de Filosofia, Letras e Ciências Humanas, Universidade de São Paulo, 2000.

KUYAMA; M. O Uso da Língua Japonesa na Comunidade Nipo-Brasileira: O Empréstimo Lexical no Japonês Falado pelos Imigrantes- Caso de Distrito Federal. São Paulo: Dissertação (Mestrado), Faculdade de Filosofia, Letras e Ciências Humanas, Universidade de São Paulo, 1999.

LABOV, W. (1994) A motivação social de uma mudança sonora. In: Padrões Sociolingüísticos. São Paulo: Parábola, 2008.

LACAN, J. (1949) O estádio do espelho como formador da função do eu. In Escritos. Rio de Janeiro: Jorge Zahar, 1998.

LACAN, J. (1961-1962) Le séminaire de Jacques Lacan. Livre IX: L'identification.

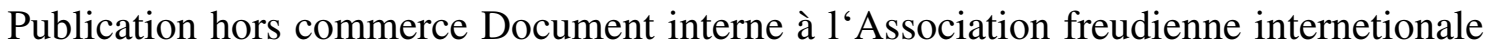
et destiné à sés membres, 1998.

LACAN, J. (1972-73). O Seminário. Livro 20 Mais. Ainda. Rio de Janeiro : Jorge Zahar Editor, 1982.

LANDOWSKI, E. (1997) Presenças do Outro. São Paulo: Ed. Perspectiva, 2002. 
LEITE, M. A intolerância lingüística na Imprensa. In: Linha D’ Água: São Paulo, n. 18,2005 p. $81-96$

LEITE, M. Q. Metalinguagem e Discurso: a Configuração do Purismo Brasileiro. São Paulo: Editora Humanitas Publicações, 1999.

LESSER; J. A negociação da Identidade Nacional São Paulo: Ed. Da Unesp, 2001.

MAGAlHÃES, M. M. M. Subjetividade em advir: A construção da metáfora em textos de alunos da escola básica. São Paulo:Dissertação (Mestrado), Faculdade de Educação, Universidade de São Paulo, 2007.

MATSUZAKI, R. H. O uso do tratamento na língua japonesa falada por nipobrasileiros : empresa bratac de bastos. São Paulo: Dissertação (Mestrado), Faculdade de Filosofia, Letras e Ciências Humanas, Universidade de São Paulo, 2005.

MENDOZA-DENTON, N. Language and Identity In: CHAMBERS, J. K, TRUDGILL, P. \& SCHILLING-ESTES, N. The Handbook of Language Variation and Change. USA: Blackwell Publishing, 2006.

MILNER; J. C (1978). O Amor da Língua. São Paulo: Artes Médica, 1987.

MOLLICA; M.C. \& BRAGA M.L. Introdução à Sociolingüística. São Paulo: Contexto, 2003.

Nawa, T. Bilingüismo e mudança de código: uma proposta de análise com os nipobrasileiros residentes em Brasília. In: Tarallo, F. (org.) Fotografias sociolingüísticas. Campinas: Pontes, 1989.

OLIVEIRA, C. G. Do rascunho ao texto final: o que motiva as transformações em textos de alunos da escola básica? São Paulo: Dissertação (Mestrado), Faculdade de Educação, Universidade de São Paulo, 2008.

ORLANDI, E. L. P. Segmentar ou recortar?.ln: Lingüística: questões e controvérsias. Uberaba, Série Estudos, n10, 1984. p.9-26. 
ORLANDI, E. P.(1981) A linguagem e seu funcionamento. Campinas, SP: Editora Pontes, 1996

OSAKABE, H. (1979). Argumentação e discurso político. São Paulo:Martins Fontes, 2002.

PÊCHEUX, M (1983a). O discurso: estrutura ou acontecimento. Campinas-SP, Pontes, 1997.

PÊCHEUX, M (1983b). Análise do discurso em três épocas. In: GADET;F \& HAK; T. (org) Por uma análise automática do discurso - Uma introdução à obra de Michel Pêcheux .Campinas-SP: Pontes, 1990.

PÊCHEUX, M. (1975) Semântica e discurso: uma crítica à afirmação do óbvio. Campinas: Editora da UNICAMP, 1988.

PÊCHEUX, M. Análise Automática do Discurso (AAD-69) In: GADET;F \& HAK; T. (org) Por uma análise automática do discurso - Uma introdução à obra de Michel Pêcheux .Campinas-SP: Pontes, 1990.

PRETI, D.(1993) Análise de Textos Orais. São Paulo:Humanitas, 2003.

RAJAGOPALAN; K. O Conceito de Identidade em Lingüística: é chegada a hora para uma reconsideração radical? In: SIGNORINI; I. Língua(gem) e identidade: elementos para uma discussão no campo aplicado. Campinas, SP: Mercado de Letras, 2001.

ROCHA, A. R. Professora Ideal: Um modelo nas revistas voltadas à categoria docente. São Paulo: Dissertação (Mestrado), Faculdade de Educação, Universidade de São Paulo, 2007.

SCHLIEBEN-LANGE, B. História do Falar e História da Lingüística. Campinas: Ed Unicamp, 1993. 
Vermes; G. e Boutet. Multilingüismo. Campinas: Ed. Da UNICAMP, 1989.

WALD; P. Língua Materna Produto de Caracterização Social In: Vermes; G. e Boutet. Multilingüismo. Campinas: Ed. Da UNICAMP, 1989. 
Anexos 
Anexo 1-

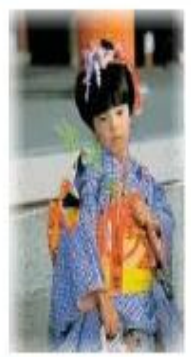

Sou Japa Com

(mtu) Orgulhu

(1.824 membros)

(ii) participar

convidar amigos

8 denunciar abuso

基 fórum

四 enquetes

표 eventos

membros

\section{Sou Japa Com (mtu) Orgulhu}

Inicio > Comunidades > Culturas e Comunidade > Sou Japa Com (mtu) Orguhu

descrição: vc tem orgulhu di ser nihondin!??!

naum liga pra akelas pssoas idiotas ki fikm mexendu com a gnt

no meiu da rua falandu "arigatoh" "sayonara"i etc i talz...?? acha os(as)japas bonitus(as)??

se você tem orguho de ser nihondin, mesmo não tendo nascido no Japão, diz pra todo mundo se é nisei ou sansei ou não sei vive falando japonês misturado com português ou fala japonês só pros gaijins não te entenderem., e acha o Japão 0 País mesmo nunca tendo ido pra lá...

e por mais tantos motivos de nós "japas" adoramos o nihon e de sermos japas, se você se encaixa neste perfil

join us...

idioma: Português

categoria: Culturas e Comunidade

dono: Faвy 4 .

tipo: pública

privacidade do aberta para não-membros conteúdo:

fórum: anônimo

local: Brasil

criado em: 30 de dezembro de 2004

membros: 1.824

fórum

$$
\text { tópico }
$$

П 0 q vc + odeia q falem dos japoneses?

IOGO DA NOTA DE OA 10

DProcuro gatas afim

口Qual foi a zuada mais podre quem alguém já te fez?

ApReSeNtAnDu.. Vai...

novo tópico denunciar spam

membros (1824)

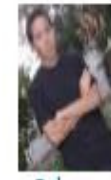

Rubens

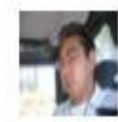

RitcagĐo MÄ $\quad$ Miyu

ssïkI_

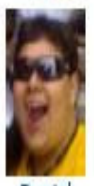

Daniel

Marcos Aguena

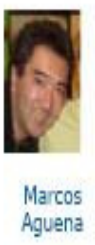

rikizinhu :D

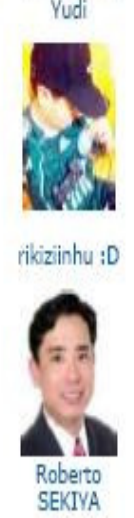

ver membres :

comunidades relacionadas
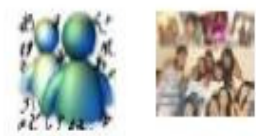

MSN -

Fàns Da Orientais - postagens última

$2202 / 12 / 08$

$255 \quad 01 / 12 / 08$

$2 \quad 29 / 11 / 08$

$41 \quad 09 / 11 / 08$
$52 \quad 14 / 09 / 08$ Orientais \& FaMiliA Na(o) Brasil

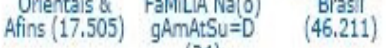

(34)

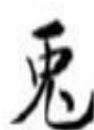

\section{每} Brasil 
Anexo 2

OrkUt I Ir Iricio Perfil Página de recados Amigos Comunidades

eniusp@ @yahoo.com.br Sair pesquisa do orkut Q Q

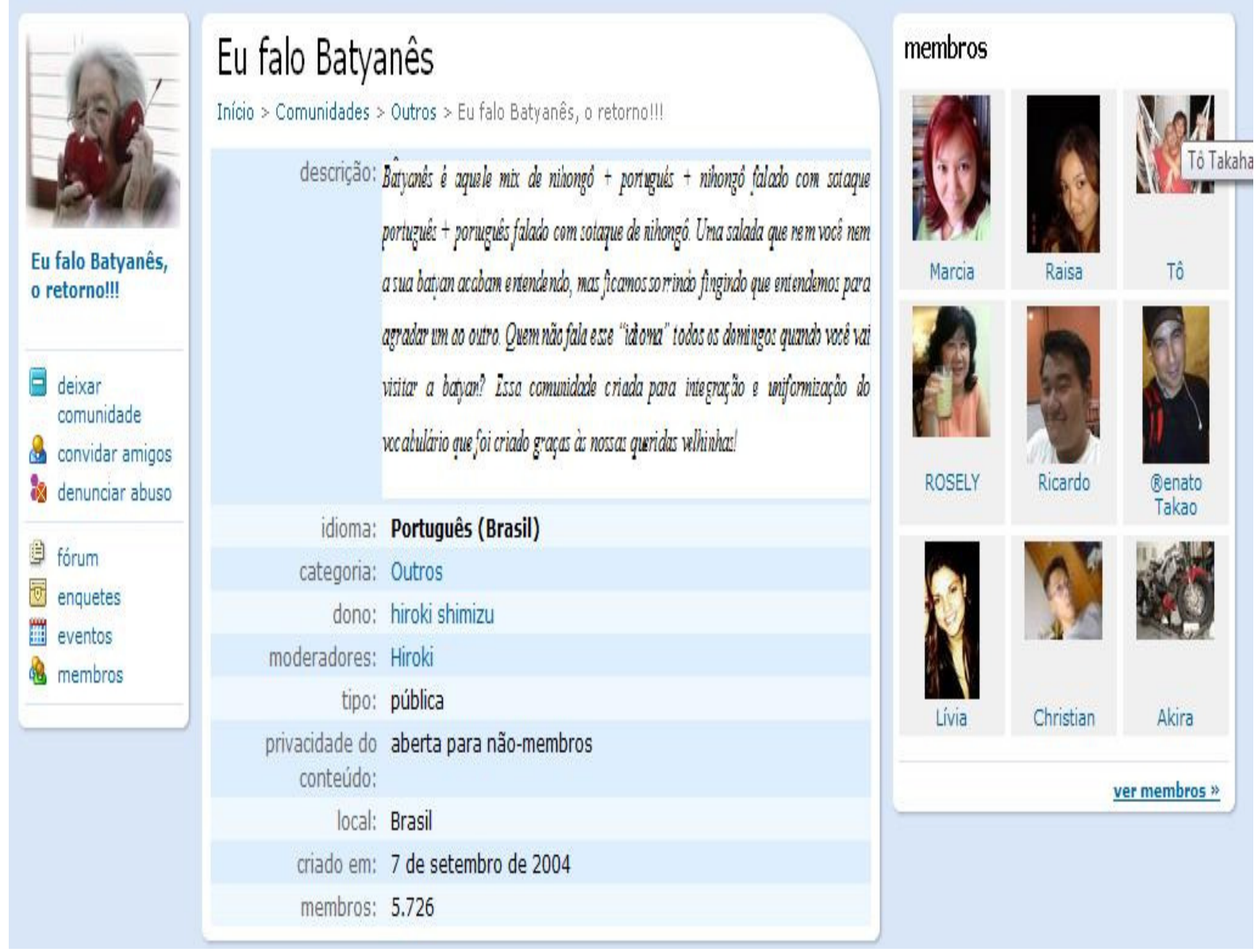


Anexo 3:

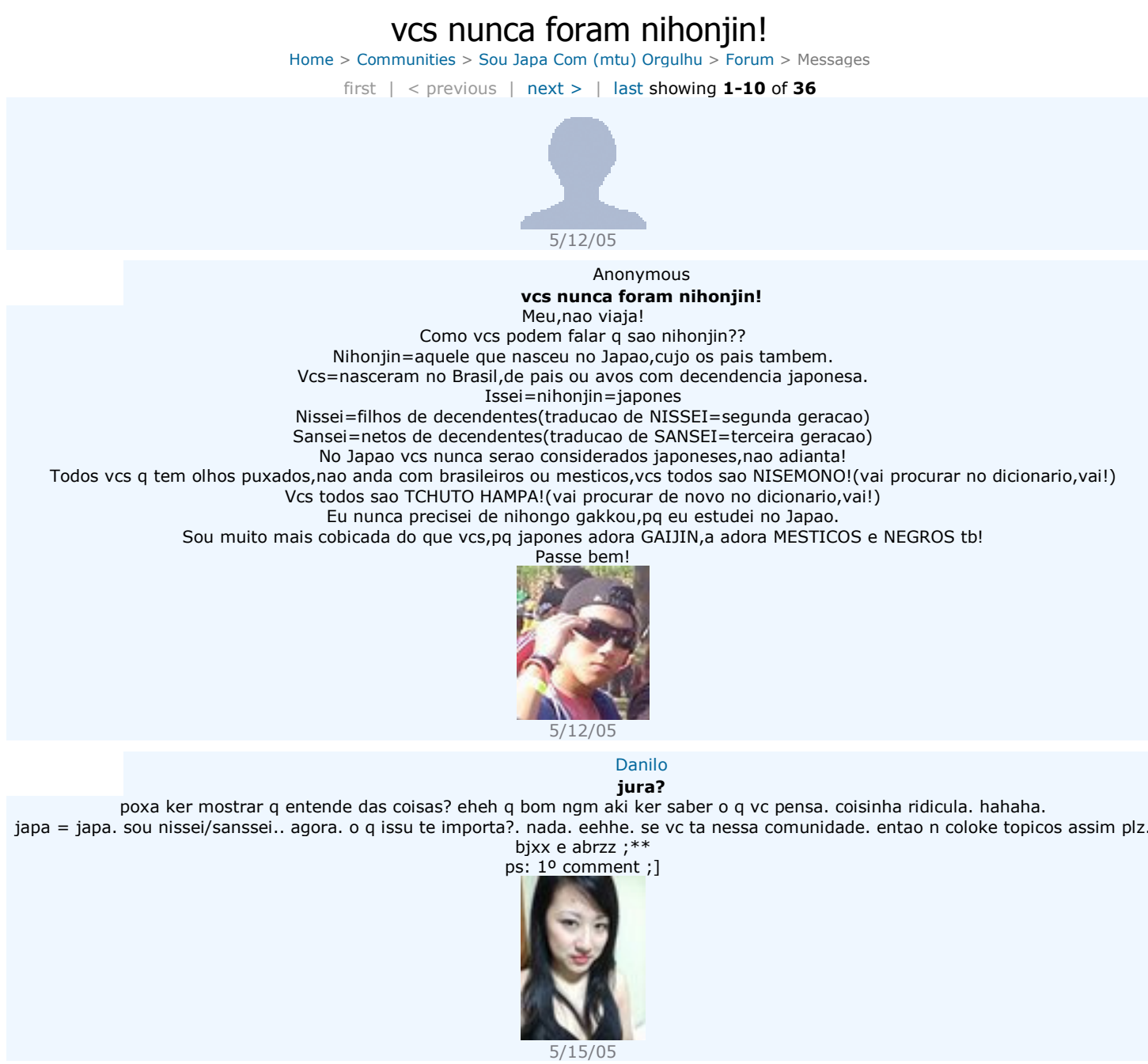

一ノ瀬

e vc $s$ axa muito nihonjin s pq estudou aki $n$ jp??s enxerga ow.......grande coisa....s vc e gaijim $\mathrm{cm}$ entro a aki $\mathrm{n}$ jp entao hein???e $\mathrm{cm}$ diz o danilo oke ta fazendo nessa comunidade entao....???e nm sao tds $\mathrm{k}$ gostao d gaijin nw viu....ou vc nw assisti tv....??? s ninguem nunca t enxeu a pasiencia nw venha enxer a nossa bl??

e tenho muito orgulho d ser sansei viu.... ow DIKOTYU......se vc tm tanto DIXIM assim pq ta anonima???

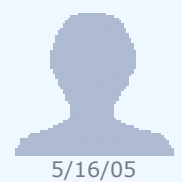

\section{Anonymous}

Sta demencia.

Aff fala seriu, que essa menina faz aki?Sera que vc nao sabe ler nao?Entao vou te soletrar do que e essa comu: S-O-U J-A-P-A C-O-M (M-U-I-T-O) O-R-G-U-L-H-O, deu pra entender Sra. C-O-B-I-C-A-D-A?O que vc entende dos gostos dos japoneses hein?vai dormir sua vagal...E que negocio e esse que todo japones gosta de gaijin e de negros?Como vc e besta minina..Ainda ta em anonimo,mas e uma covarde msm ne?

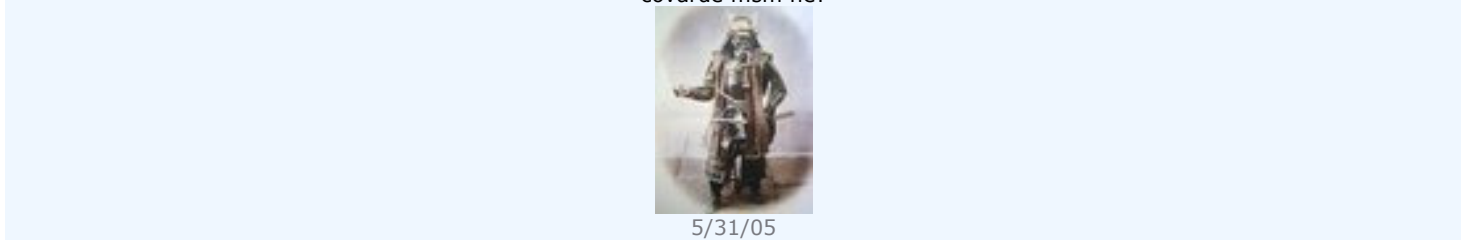

$$
\text { 彰男 (AKIO) }
$$

ae, c alguem quiser saber oq é gaijin ta ai!

todos nós sabemos q no japao nunca vamos ser aceitos, nem no brasil e nem inferno nenhum.

mas $\mathrm{p}^{* * *} \mathrm{~m}^{* * * *} \mathrm{c}$ vc c acha tao gostosona tao mais q uma nihondin qualquer esta totalmente enganada. vc so é um monte de carne q tem "olho grande" e q vai virar esterco e nem vai ser lembrada, senhorita cobiçada

obs.: o zoio grande nunca adorei gaijin, negro, mestiço, qualquer um desses, as unicas pessoas q eu algum dia gostei foram todos nihondin, pois naum tinham esse pensamento tao mesquinho. 


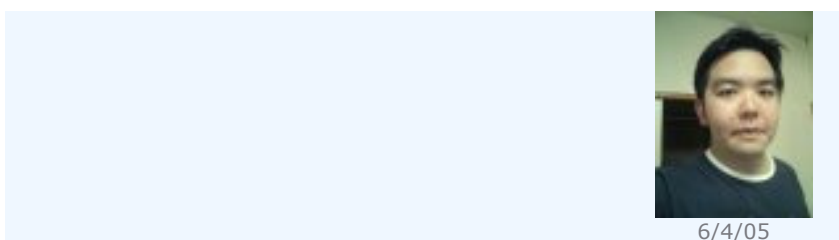

$6 / 4 / 05$

$\star$ M A S S A

hummmm.... interessante

Lento o post da anonima, tirei algumas conclusoes..

Bom.... em partes, ela tem razao!

Vou tentar explicar!

O Japones tem muito orgulho em relaçao a sua raça... E de fato, e uma raça admirada pelo mundo inteiro, pela sua educaçao, determinaçao, inteligencia, e por muitas outras qualidades!

Nossos avos, q sao japoneses, imigraram p o brasil, e tiveram varias dificuldades, etc... Mas uma das principais luta deles foi a de preservar a cultura japonesa entre seus descendente, ou de preservar a raça japonesa, realizando casamentos entre japoneses e de certa maneira, condenando casamentos entre os nao japoneses ou descendentes com os "japoneses"!

Desde criança, somos educados, de certa maneira, ouvindo q somos japoneses..... q devemos ter orgulho de nossa raça, etc... qualquer uma q tiver uma batian ou ditian, e conversar mto com ela, acho q ja ouviu conversa deste tipo..... q somos japoneses e devemos ter orgulho!!!

Pessoal... moro no japao, sou descendente de pai e mae nissei, minha cara e de nihondim mesmo! mas escutem bem o q vou falar .... o q vou relatar é um depoimento pessoal mesmo...

Quando eu cheguei no japao, fiz amizades com varias pessoas, inclusive japoneses... um dia eu falei $p$ um $q$ eu tbm era japones!!! sabe qual foi a reaçao dele? riu na minha cara!!!! mas ai eu falei.... po! mas eu sou puro! n sou misturado com nenhuma outra raça! ele $n$ quis nem saber!

Sabe.... isso foi meio q um "soco" na minha cara.... poxa.... desde crianca fui educado no brasil q era japones, e quando chego no japao, e digo q sou japa, riem na minha cara!? sacanagem!!!!

mas infelismente e isso mesmo..... fomos enganados por nossos pais ou avos!!!! eu sou BRASILEIRO!!!!! de japa, so tenho a cara!!!!

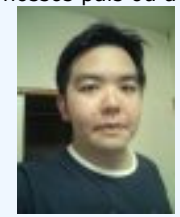

$6 / 4 / 05$

$\star$ M A S S A

continuando..

Hoje, caso algum gringo me questionar, ja sei o q responder...

$\mathrm{Hj}$ digo q sou descendente de japoneses, 3 geraçao, nascido no Brasil, entao sou BRASILEIRO!!!!!! e completo ainda.... q SOU MTO FELIZ POR ISSO!!!! n vou ficar falando mal dos japas, mas sou mto feliz mesmo de ter nascido no brasil.... apesar da situaçao de merda q o pais se encontra.... As pessoas q nascem e vivem no brasil sao unicas! inexplicavel!

Bom.... agora vou falar sobre um outro ponto q a anonima abordou...

Ela tentou ridicularizar as pessoas q se acham "nihondin's"..

Esta atitude ou reaçao dela, so pode ter uma razao...

Ela, por ser mestiça(eu acho q ela e, pelo q ela escreveu) deve ter sofrido mta discriminaçao, ou de alguma maneira, q eu $\mathrm{n}$ entendo o motivo, deve ter se sentido inferior, por ser mestiça...

Eu ja conheci um tipo assim.... q antigamente, sofreu mta discriminacao pelos outros familiares "puros", por ser mestiço, e quando teve a oportunidade, tentou satirizar a mim, quando comentava uma vez, sobre as coisas q eu passei, relatando o meu caso com o japones q riu na minha cara!

Mas de boa.... depois ele me explicou q nunca gostou deste orgulho dos descendentes de querer se achar os melhores, apenas por serem "descendentes puros", e q sofreu mto por n ser tbm! Ele dizia q frequentava muito os eventos da colonia, e muitas vezes, diziam na cara dele, q ele $\mathrm{n}$ era "japones", e ficavam ridicularizando ele por isso... mto triste! Tudo isso e mto triste mesmo! Triste saber q existem pessoas com esta mentalidade!

O mundo mudou! $\mathrm{n}$ devemos mais ficar brigando por besteiras como esta!

e anonima.... vamos parar com estas criancisses, blz? quem vai estar dando uma de ridicula vai ser vc mesma!

$\mathrm{N}$ se ache melhor do q ninguem por vc ser isso ou aquilo... $\mathrm{n}$ cometa os mesmos erros q outras pessoas cometeram com vc..

Usa um pouco a cabeça!

e isso galera.... espero q tenham entendido o q eu quis passar aqui nestes posts!

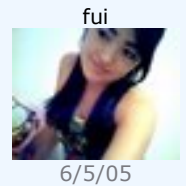

Yumiii $\star$

aff..

como se vc fosse nhe.

af af af..

e uma coisa.

eu jah morei no Japão.

qm disse q eles adoramn engros?

eles sao racistas.

eles judiam se algum negro vai pra lá.

vc nem sabe...

eles judiam dos mestiços tbm.

eu naum sofri isso pq sabia fala japones.

mais jah vi mtos mestiços chegando do Brasil naum sabendo fala japones e sendo judiados..

aff 


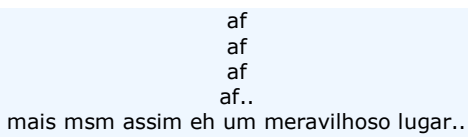

mais msm assim eh um meravilhoso lugar..

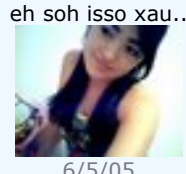

Yumiii $\star$

aew

vcs naum sabem.

mais eles podem aceitas os mestiços assim como eu fui aceita lá. e sou aceita aki..(brasil)

pq na $1^{\text {a }}$ q algm me zoa q sou japa eu naum ligo..

pq o japão eh um ligar maravilhoso e eu tenho mto orgulho de ser descendente de lah..é só fala isso..

mais lah no Japão..

se eles quiserem t zua msm.

nossa vc sofre,"

eu jah vi kda gnt sofrendo tantoo.

mais meu assim

se vc sabe fala japones..e saber se defender..eles klam a bok..hehehe

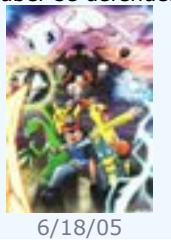

\section{ダヤネキミエ}

ois

nossa mto nada vê nós somos nihonjins plo q somo, ñ por onde nascemos, tipo eu, eu sou ninsei mtos me consideram como nihonjin msmo, td mto nada vê.

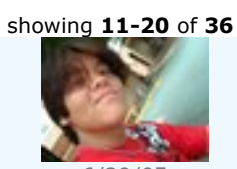

$6 / 29 / 05$

\section{Hércules Makio.}

tpw se vc acha q nois naum samo nihondin .... eu $\mathrm{n}$ ligo mais eu so pelo meu jeito :D naum pelo q os outros pensam ;) by Hercaummmmmmmmmmmmmmmmmmmmmm
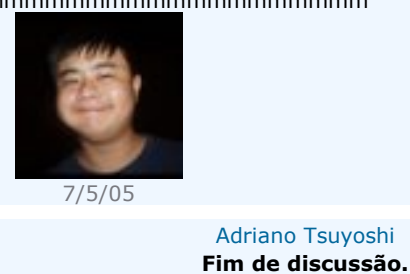

Nóis é JAPA.

Se nóis fosse NIHONJIN nóis não ia ser japa.

Porque japa é descendente de nihonjin nascido no Brasil.

Como diz aquela empresa de produtos eletrônicos, "os nossos japoneses são mais criativos que os japoneses dos outros". (apesar de não gostar do jeito que eles dizem isso)

E tenho orgulho de ser especial.

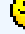

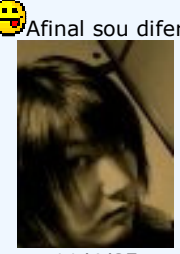

$11 / 4 / 05$

中村 ヤスオ

hahahaha...

BOM EU PASSEI AQUI DEPOIS DE MUITO TEMPO E VI ESSE TÓPICO, E NÃO PUDE DEIXAR DE ESCREVER O Q PENSO!!!!!!!! PRIMEIRAMENTE A PESSOA QUE FEZ ESSE TÓPICO TÁ VIAJANDO !!!!

POIS Q EU SAIBA NIMGUEM NASCE SABENDO DAS COISAS, SE VC ESTUDOU AQUI NO NIHON MEUS PARABENS, VC TEM MAIS CHANCES DE UM EMPREGO MELHOR!!!!!!!!!!!!!!!

EU TO AQUI HÁ 6 ANOS ( EU SEI Q NIMGUEM TEM A VER COM ISSO), MAS APRENDI PELO MENOS A ME COMUNICAR COM AS PESSOAS E FIZ MUITOS AMIGOS JAPAS( ORIGINAIS DAQUI)!!!! TANTO QUE ESSES MEUS AMIGOS FALAM QUE SER ISSEI, NISSEI ,SANSEI OU 
MESTIÇO "NÃO TEM NADA A VER", POROUE SOMOS TODOS IGUAIS ( SERES HUMANOS)!!!!!! E OUTRA MINHA FILHA, JAPONES GOSTA PESSOAS QUE TEM CARATER ( OBVÍAMENTE COISA QUE "VOCE" NÃO TEM) E NÃO PELA ETNÍA SE VOCE ACHA QUE É MAIS COBICCADA PROBLEMA É SEU ,POIS FIOUE COM ESSE SEU PENSAMENTO MEDIOCRE!!!!! POIS SE VOCE FOSSE UMA PESSOA DESCENTE, EU ACHO QUE NÃO ENTRARIA NESSA COMUNA SÓ PARA ESCREVER MERDA E AINDA POR

CIMA EM ANONIMO!!!!!!

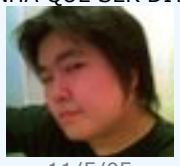

$11 / 5 / 05$

Rick

Kra tu nadou na lama

Teme shika, se liga meu chapa !! fuizzzz

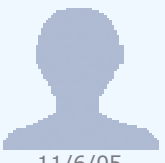

$11 / 6 / 05$

Anonymous

O que importa eh o sentimento de ter orgulho

Anomino....Mew...Na boa...vc eh mto lesado, sabe poq?

Primeiro se vc fosse ao menos digno(a) de dizer o que dise mostaria a kra.

Segundo você não deve levar em conta regras e regras de ISEI, NISEI, SANSEI,YONSEI...ETC ETC....Poq o que conta eh o sentimento de ter orgulho da raça.E não o sangue que corre nas veias.

Terceiro se vc é tãooooooo inteligente qnd se mostra ser, guarda isso pra vc mew, querer aparecer,se mostrando o bom e não se idêntificar....sinceramente...Não dá pra engolir!!!!

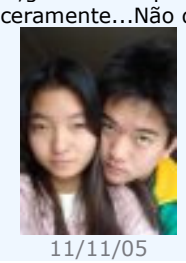

$11 / 11 / 05$

nussa!!

Lucas Muraguchi

Zeus do céu..

kem escreveu o topico tava maconhaaaada...

aushuahsuahua..

o ke uma coisa tem a ver com a outra?

nussa, jah ouvi e li esse seu discursinhu em um motne de lugar...

mas ele naum cabe a essa comunidade...

nunka falei ki sou nihonjin, sou JAPA, e tenhuorgulho disso...

porra.a...

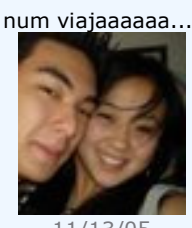

$11 / 13 / 05$

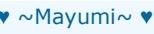

ualll

esse eh bom entendedor.. hauhauhauhuahuaha!!!! vai caga ow!!! q garoto mais sem noção!!!

q merdaaaa!!!

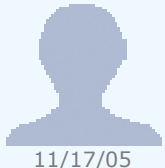

Anonymous

hahahahahahahahahaha!!

soh tm loko no orkut!!! 


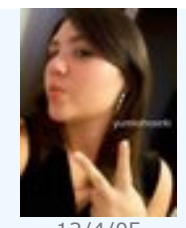

$12 / 4 / 05$

\section{${ }^{\circ} \mathrm{pSiu}{ }^{\circ} \mid$.yúh}

Nuss

A mew fafa seriu

tipo assim eu tbm jah

morei e estudei no Japão

$$
\text { foraum } 4
$$

m-a-r-a-v-i-l-h-o-s-o-s

Anos...realmente lah rola

mtu preconceito sim. Mas

comigo nunca teve problemas, não!!!

Eh lugar exemplar e tenhu orgulho

de ser Nihondim!!!!!!

(E ESSA ANONIMA Q VA AH MERDA)

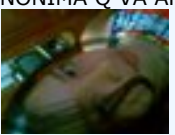

$12 / 25 / 05$

Alfnete aka 최용미

Soh pra sabe qm pediu sua opiniaum???

Tah c axandu neh!!! Soh pq nois naum nascemu no japao mas dah 1 ligue no nome da camunidade "sou JAPA com (mtu) Orgulhu" Dizemos q somos Japas e essa historia d nissei sansei e etc e a parte blz??? 
Anexo 4: 
Anexo 5

\section{$\mathrm{e}=$ entrevistador}

i: informante-1

e: bOm então vamos começar pela história sua Lívia... vocÊ é ...

i: eu sou descendente de japonês \{

e:

é..

i: terceira geração:

e: terceira geração

i: eu moro com meus \{

e: $\quad$ conta um pouco da história/ contextualiza sua história de descendente...

como é que você contaria como descendente de japonês ... numa apresentação em um programa de relacionamento à procura de um namorado (risos)

i: ah:: bom meus avós por parte de pai e por parte de mãe vieram do japÃO ... -- ih::: e que mais. não sei o que falar/ não sei ( ) da minha história de descendente sei lá-- eles vieram do japão trabalharam aqui com agricultura aí meus pais nasceram e se casaram e eu nasci

e e i: (risos)

e: e você se considera japonesa ou brasileira lívia?

i: ah: uma brasileira:: japonesa que eu acho que tem bastante diferença assim... sÓ pelo aspecto físico as pessoas jÁ:: te colocam num grupo

e: uhn

i:não só os próprios japoneses mas as outras pessoas que não são descendentes já te não que te excluem mas já te categorizam ah: os japoneses. é diferente assim as pessoas são descendentes de italianos de franceses ou de espanhol mas ninguém fica lá categorizando ah: o espanhol né quando é japonês ah: o japonês o: japa japinha sempre entra no grupo dos japoneses. eu acho que:: a cultura japonesa ela é muito diferente então acho que não tem como não sentir essa diferença\{ e:

uhn diferente como assim/ o que você acha que tem a mais para o fato dessa cultura ser nomeada e as outras não?

i: então eu acho que o aspecto físico conta bastante

e: uhn

i: e eu acho que a comida: muita diferente e porque é uma cultura oriental acho que se diferencia bastante da cultura ocidental nos hábitos na postura na linguagem também mas na nossa geração já não faz tanta diferença eu acho éh:: eu acho que na forma de pensar num todo assim $\{(\ldots)$

e: $\quad$ uhn e da sua parte brasileira ... por que você acha que é uma brasileira japonesa e não uma japonesa brasileira

i: AH:: porque como eu tive bastante contato com ... descendentes que consideram muito os japoneses ou com pessoas que moraram no japão pessoas que se identificam muito com a cultura japonesa. eu vi que eu gosto da cultura japonesa admiro vários aspectos da cultura japonesa mas muitas coisas assim eu não me identifico muito mais e também eu me identifico com várias coisas da cultura que não é japonesa né: da cultura brasileira não sei como definir a cultura brasileira que é uma mistura

e: e assim dentro dá/ entre os japoneses porque sempre tem aquela coisa de tentar ver quem é mais japonês assim aí: fulano é nissei fulano é sansei

[

i: éh:: 
e: sei lá igual o meu sempre era o susto\{ porque como pode o enio ser mestiço i:

e: ele tem o olho\{ muito puxado

verdade

i: $\quad$ ÉH:: nem parece ser mestiço

e: não podia ser mestiço

i: e o seu sobrenome é japonês néh então não parece\{

e:

AHN mas aí era muito engraçado era

muito engraçado porque tinha umas coisas assim tipo quando eu encontrava as amigas da minha avó elas falam coisas quase como "ah não liga que você é mestiço se você ficar quetinho e se comportar bem ninguém nem vai perceber” SAbe:\{ i: nOSsa:: tipo não fala

e: e já aconteceu com você ou é muito tranqüilo pra passar por japonesa

i: várias pessoas acham na verdade ao contrário que eu sou mestiça

e: um

i: muita gente já perguntou se eu sou mestiça mas sempre:/ nunca senti assim um preconceito uma descriminação assim negativa

e: uhn

i: eu acho que os japoneses eles são descriminados no sentido de que eles são categorizados num grupo isolado sabe são os japoneses mas não negativamente e:uhn

i: é diferente de outros grupos... outras minorias ou outras raças ou sabe/ pessoas que tem outras histórias outras culturas que se sentem descriminados negativamente que se sentem rebaixados acho que os japoneses são o contrário aí japonês tem/ sempre aparece aquelas coisas assim "aí japonês é inteligente" "japonês é disciplinado"sempre senti isso

e: uhn

i: sempre cheguei nos lugares assim "aí japonesa aí muito/ deve ser muito inteligente sabe" "deve ser bonzinho"

e: sempre como um fato positivo

i: sempre como um fato positivo nunca senti como um..

e: uma certa hostilidade

i: não

e: éh:: vem meio junto né: tipo vocês são/ são muito bom mas vocês roubam a nossa vaga na fuvest

i éh:: vem mas eu não me incomodo a gente rouba mesmo e aí?

e e i: (risos)

i: o problema é de vocês ... não brincadeira mas acho que é mais para o lado positivo assim

e: táh.. táh

i: você nunca entra numa empresa ou você nunca deixa de entrar numa vaga pensando assim "ai porque eu sou japonesa eles não me quiseram"

e: uhn

i: porque nos outros casos a pessoa pode falar "ah: não porque eles não me quiseram assim porque eu sou alta demais gorda demais loira demais negra demais sabe no caso japonês eu acho que geralmente não tem isso ai

e: não tem ... ahn ahn assim tipo na escola você nunca se sentiu meio rejeitada também

i: na escola ...é que eu estudei em escola publica mas na minha escola tinha muito japonês na região que eu moro no bonfiglioli tem muito japonês e: uhn 
i: então::

e: era muita gente néh:: (risos)

i: assim não dava para excluir a gente a gente néh: que ia acabar excluindo as pessoas

e: aham

i: porque a gente se unia muito assim/ é a gente acabava se isolando um pouco

e: um

i: o grupo de japonês era muito forte a gente acabava se unindo porque os pais se conheciam os avós se conheciam a gente tinha as mesmas atividades a gente saia e começa a ir para festinhas

e: uhn

i: mesmos lugares néh

e: e na escola tinha o contrário? assim do grupo acaba excluindo

i: dos japonês excluir ...

e: hum

i: outras pessoas?

e: hum

i: eu acho que tem assim quando eu era criança eu acho que eu não tinha tanta consciência mas agora assim pensando bem eu acho que tem sim porque nossos avós...

e: uhn

i: não: sei se meus pais têm também mas eles incentivam a andar mais com japoneses. meus avós com certeza ...

e: uhn

i: a primeira coisa que minha batyan pergunta quando começa namorar: "é gaijin? é gaijin ou nihonjin"?

e: pode ser curiosidade?

i: a não... ela fala gaijin não presta... é estranho ela falar isto porque ela tem filhos casados com não descentes e mesmo assim ela continua com essa pergunta

e: batyan é batyan

i: batyan é batyan ela já tem noras assim que não são japonesas e ela persiste nas netas assim

e: nihonjin

i: ou então quando a gente apresenta assim um amigo que não é japonês mas é super bonzinho super legal ela fala assim: "ah:: é gaijin mas é tão bonzinho" como se fosse não ser japonês uma característica ruim mas é compensado pelo fato dele ser bonzinho sabe

e: ahn(risos)

i: é bem assim

e: e você acha que está ligado mais a uma (...) discriminação do gaijin ou uma tentativa de preservação do/ da cultura mesmo assim.

i: ah:: eu acho que éh: hoje em dia

e: hum

i: não tem mais o porque/ fazer essa discriminação mas acho que meus avós viveram em uma época que eles sofreram muita descriminação ... assim minha mãe sofreu muita descriminação quando era criança/ ela estudava em um colégio em que só ela era budista então na aula de religião ela ficava fora da classe ela era a única criança que não assistia as aulas

e: uhn

i: e:: meus avós viveram época de guerra néh\{

e:

mas ela não assistia porque era ela impedida

de ou porque ela não queria 
i: AH:: eu não sei

e: pela fala assim pelo que ela fala

i: AH:: parece que ela era tirada da sala pelo que ela falava assim mas não sei se era porque a escola não deixava ou se era porque meus avós os pais dela não queriam

e: uhn

i: eu não sei

e: uhn

i: mas eles sentiram muita descriminação/ na geração dos meus pais na geração dos meus avós eles sentiram muita descriminação então assim

e:uhn

i: atualmente eu acho que não tem porque... mas acho que eles já tiveram/ já sofreram muito com isso e acabaram criando essa barreira como uma forma de defesa da cultura e: uhn

i: das origens da família

e: quando eles chegaram aqui eles eram a minoria eles sofreram muito acho que com o trabalho deles e acho que eles acabaram se unindo mais

e: uhn

i: como uma forma de defesa

e: ham

i: então hoje em dia eu acho um absurdo a gente vai na liberdade e fica aquelas batyanzinhas assim falando "aí::" sei lá "gaijin" não sei o que e as vezes assim são pessoas que admiram muito a cultura japonesa respeitam muito

e: uhn

i: ( ) fazem de tudo para se integrar nessa cultura e são muito descriminados mas por outro lado eu entendo o lado deles/... eu acho que eles sofreram descriminação quando eles chegaram aqui principalmente na época da guerra que o japão ficou contra o brasil

e: éh:: o japonês foi inclusive proibido de ser ensinado/ de ser falado

i: é: então eu acho que eles têm os motivos deles

e: uhn

i: a gente tem que conversar assim com a batyan "não batyan não é assim não é só japonês que é bom tem japonês ruim também néh batyan

e: (risos)

i: ai a batyan fica "éh néh: éh néh" ai depois passa uma semana assim ela faz a mesma pergunta

e e i: (risos)

i: éh: não muda a opinião não adianta querer mudar a batyan agora com oitenta anos

e: e as gerações mais novas que você assim suas primas e sua irma mais nova como ... você acha elas lidam com a batyan/ você acha que uma diferença?

i: hum: aí:: pelo menos em casa assim eu acho que não

e: hum

i: eu acho que depende muito da família porque a nossa família não está tão ligada à cultura japonesa assim/ as famílias do interior assim por exemplo assim o missal que mora em atibaia lá a cultura japonesa é muito forte... todo mundo joga yakiu todo mundo faz aquelas danças japonesas participa das festas japonesas tudo como atividade da comunidade

e: ham

i: e hoje em dia assim na minha família a gente não tem nenhuma atividade ligada a cultura japonesa

e: uhn 
i: só a minha irmã mais nova que ela É:: escoteira e é de um grupo que coincidência ou não tem muito japonês

e: uhn

i: e aí acaba influenciando acaba tendo mais atividades relacionadas acaba tendo aquelas festas que tem udon comidas típicas assim mas não é muito forte a presença da cultura japonesa não é:::/ não se sobrepõe assim as outras coisas da vida

e: ah: entendi/mas você acha assim que você freqüentou mais coisas japonesas do que sua irmã mais nova ou não?

i:eu acho assim que não está ligado a diferença das gerações assim eu fiz letras japonês acabei me interessando mais

e: uhm

i: tanto a irmã mais velha quanto a minha irmã mais nova não tem assim esse interesse

e: hum::

i: a minha irmã mais velha namora com um não japonês e minha irmã mais nova com um japonês

\section{$\mathrm{e}=$ entrevistador}

\section{i: informante-2}

e: agoRA: acho que esta indo\{

i: $\quad$ agora está gravando

e: ai:: fuji a gente vai começar. só o básico... você tem vinte anos e é sansei

i: isso...

e: tá então quem é nissei?

i: meu pai

e: seu pai é nissei e a sua bathian?

i: ( ) minha bathian é japonesa mesmo

e:que você sabe da história da sua bathian fuji?

i: putz... ela veio do japão com avó fugindo da segunda guerra.. ai:: eles foram para tupã ou Ibiúna/ sei lá pra alguma cidade do interior aí: AÍ meu avô voltou pro japão porque ele... porque ele queria levar o pessoal de volta eram cinco filhos /aí ele queria levar minha vó meus tios e meu pai de volta pro Japão... aí ele ficou lá tipo uns quinze anos quinze anos... não mais uns vinte e cinco anos ... aí depois quando ele voltou falar com minha vó ele já tinha outra mulher e outros filhos lá então minha vó ficou aqui e aí ele ficou por lá mesmo e minha vó sempre morou aqui trabalhou aqui e aí foi tudo aqui no interior de são paulo.

e: a sua vó chegou a trabalhar?

i: SIM ha muito tempo atrás 
e: ta então sua vó não era bancada pelo seu avô?

i: não/ ainda mais porque ele foi para lá e não mandava dinheiro ...

e: e os seus tios e seu pai foram pra lá/ ficaram aqui?

i: não eles ficaram aqui... meu tio não meu tio avô tinha uma farmácia que ai-- mas era uma farmácia da família inteira assim praticamente-- e aí:: meu pai começou a trabalhar lá junto com meu tio e aí quando meu tio avô morreu essa farmácia ficou pro meu pai e um outro tio meu mais aí depois na verdade pra um tio e duas tias aí meu... eles desistiram meio que da parte deles ficou pro meu pai

e: e a sua mãe é brasileira?

i: minha mãe é brasileira

e: você sabe da história da sua mãe e do seu pai por exemplo a minha mãe foi a desgraça da família

i: a minha mãe também foi a desgraça da família assim eu sei não como eles se conheceram isso eu não lembro não mas eu sei que tipo quando eles se conheceram aí minha mãe gostou meu pai e tal aí na casa dela meu vô era... bebia um pouquinho Só e aí batia em todo mundo/ aquela beleza... E:: aí minha mãe depois de um tempo namorando meu pai resolveu casar e aí meu pai por ser o mais velho ele tem que ficar com a mãe né.. teria que ser o último a casar e levar a mãe pra casa dele e tudo mais aí ele foi o segundo a casar acho e aí ele falou não vou morar com a minha mãe eu vou com a minha esposa e tudo mais e aí foi a maior briga porque todo mundo achou que minha mãe estava interessada só no dinheiro e não sei o que e tanto é que minha tia começou tipo que meio que sabotar a farmácia para não ter tanta grana pra ver se minha mãe desistia achava que era só por causa de grana aí ninguém gostava da minha mãe minha vó brigava com minha mãe minhas tias todo mundo fazia cara feia (fala) xingavam minha mãe em japonês pra ela não entender aquelas várias coisas

e: suas tias falam japonês ?

i: É:: um tio meu está na Japão... tem uma tia minha no japão e tem uma tia minha que mora com minha vó então ela fala japonês com minha vó todo dia com minha vó e duas outras dias também

e: e sua vó já fala um pouco de português?

i: fala mas bem pouco porque normalmente ela passou a vida assim só com os filhos e::: e os filhos então ela só precisava falar japonês assim então ela não sabe muito português não

e: como é o relacionamento dela com os netos. você fala em português e ela responde em japonês?

i: é a gente fala em português com ela normalmente e aí ela responde o que ela consegue em português e as vezes ela manda um japonês ali no meio mas ela consegue 
entender tudo o que a gente fala em japonês em português quer dizer só de vez enquanto da um negócio aí ela não sabe a palavra em português mas é assim com todos os netos vários e todos só falam em português com ela.

e: e os netos então nenhum fala japonês ?

i: não tem alguns que até falam assim mas normalmente a conversa é português até porque é costume falar português então acaba saindo em português e a gente nem lembra na verdade de falar japonês. mas na maioria das vezes a gente usa português

e: e como foi a sua experiência na escola japonesa?

i: foi legal foi muito boa eu fiz eu tentei fazer duas vezes a primeira era de sábado eu curtia muito a aula mas tava com sono porque a aula era sábado de manhã mas a aulka era muito legal eu adorava ir pra aula de japonês só que eu estava com sono então não aprendia aí depois foi difícil assim porque a professora era muito legal de sábado também aí putz eu falei de sábado não dá pra fazer eu vou fazer de dia de semana a noite mas aí duas coisas pegaram a professora não era tão legal e tão boa e a galera que ia era tudo executivo. japonês é quieto executivo é mais aí não rolava porque eu era o único que queria falar e tudo mais conversar com todo mundo e zuar e aí não dava e aí foi meio chato por causa disso por a galera ser mais oriental mesmo e aí não foi tão legal mas a aula era muito boa assim eu gostava pra caramba

e: na turma de sábado o pessoal era mais ...

i: na turma de sábado era mais gente da minha idade também né putz eu tinha 1817 anos e a galera era mais ou menos isso também 1617 era todo mundo junto ali e a gente conversa.

e: maioria descendente?

i: maioria descendente não tinha nenhum que não era todo mundo era descendente já na parte que eu fiz a noite tinha dois caras ou um cara e uma mulher que eram brasileiros eles estavam fazendo porque gostavam só mas na parte de sábado todo mundo era descendente

e: você disse que você é brasileiro e japonês então fale um pouco de cada lado assim por que é que você acha que você é brasileiro? e por que você acha que é japonês?

i: eu acho que eu sou brasileiro porque eu falo demais porque eu me relaciono demais com as pessoas assim na parte de abraçar pegar coisas que japonês não faz muito mesmo com os melhores amigos assim você não vê um japonês assim abraçado ou sei lá fazendo coisas assim de contato físico mesmo. então nesta parte eu acho que eu sou mais brasileiro assim na parte bangunceira também e de preguiça.

e aí a parte japonesa que com as minhas coisas eu sou organizado aí já não depende do outro assim é uma coisa mais solitária assim eu já sou organizado eu tenho tipo meio que um $\{\ldots\}$ disciplina para fazer as coisas e tal então nessa parte eu já me vejo mais japonês algumas coisas meio que invejo parte japonesa e tal assim ensinamentos e tudo mais aí tento aprender nessa parte eu sou mais oriental 
e: e o seu ciclo de relacionamento é mais brasileiro do que japonês?

i: meu relacionamento é mais brasileiro do que japonês porque eu brinco converso falo abraço corro (atrás)

e: não eu falo assim dos lugares que você freqüenta?

i: dos lugares que eu freqüento é mais brasileiro é verdade

e: tipo as amigas japas $90 \%$ dos amigos delas são japas aí elas freqüentam baladas japas

i: nunca fui pra balada japa não gosto de comida japonesa então não freqüento restaurante japonês putz eu não tenho muitos amigos japas então também não vou muito na liberdade assim também por exemplo. putz o que eu mais faço de japa é escutar jrock e j-pop ler mangar e ver anime é parte japonesa que eu tenho eu posso dizer mas de freqüentar lugares conhecer pessoas não é muito não

e: e com a língua japonesa como era o seu contato? 